\begin{tabular}{l}
$\begin{array}{l}\text { 2. To: (Recoiving Organtiation) : } \\
\text { Waste Management }\end{array}$ \\
$\begin{array}{l}\text { 5. Prof/Prog/Dopt/DW.: } \\
\text { W-178. }\end{array}$ \\
\hline
\end{tabular}

\section{Originator Remark:}

For Release
3. From: (Origliting Organteation)
Eluor Danial Northwest
6. Dealgn Authority/Deion Aoshticos. Engr.:
David S. McShane

4. Related EDT No.:

$\mathrm{N} / \mathrm{A}$

7. Purchase Order No.:

$\mathrm{N} / \mathrm{A}$

9. Equip./Component No.:

$\mathrm{N} / \mathrm{A}$

10. System/Bidg./Facility

219-S

12. Major Aasm. Dwg. No.:

$\mathrm{N} / \mathrm{A}$

13. Permityermik Application No.:

$\mathrm{N} / \mathrm{A}$

14. Required Response Date:

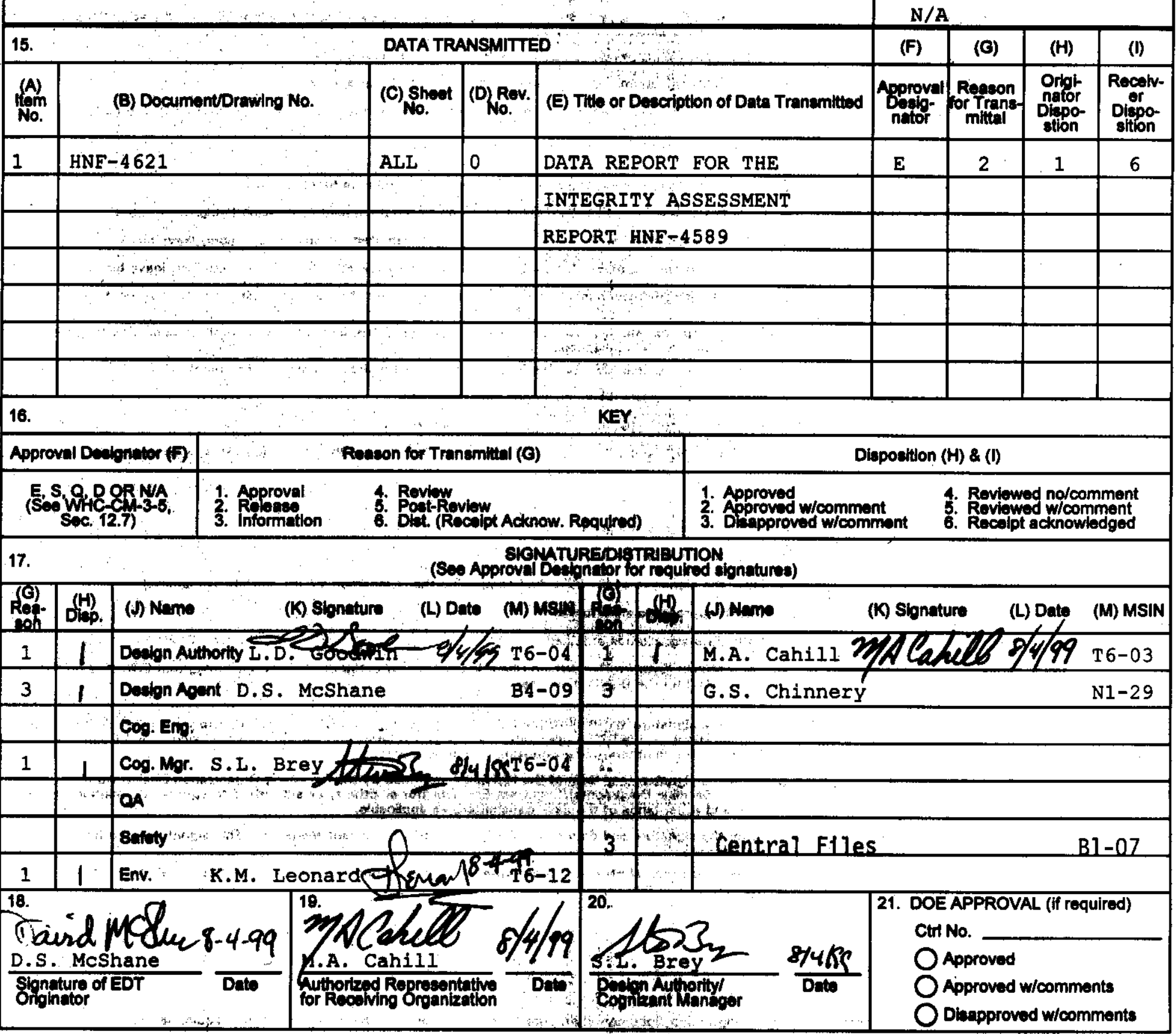

11A. Dedign Baseline Documontr $O$ he $O$ No
N/A

KaY 


\section{Data Report for the Integrity Assessment Report HNF-4589}

\section{David S. McShane}

Fluor Daniel Northwest

Richland, WA 99352

U.S. Department of Energy Contract DE-AC06-96RL13200

$\begin{array}{lll}\text { EDT/ECN: } & 626183 & \text { UC: } 2000 \\ \text { Org Code: } & 08000 & \text { Charge Code: } \\ \text { B\&R Code: } & \text { EW31300000 } & \text { Total Pages: } 76\end{array}$

Key Words: Integrity Assessment, W-178, W-087, 219-S, 222-S, Tanks TK-101 and TK-102, System, Corrosion, Inspection

Abstract: Supporting data for the Integrity Assessment Report of Tanks TK-101 and TK-102.

TRADEMARK DISCLAIMER. Reference herein to eny specific commercial product, procese, or service by trade name, trademark, manufacturer, or otherwise, does not necesearily constitute or imply its endorsement, recommendation, or favoring by the United states Governient or any egency thereof or its contractors or subcontractors.

Printed in the United States of America. To obtain copies of this document, contact: WHC/BCS Document Control Services, P.O. Box 1970, Mallstop H6-08, Richland Wh 99352, Phone (509) 372-2420; Fax (509) 376-4989.

Wanis Rasalal $10-27-99$

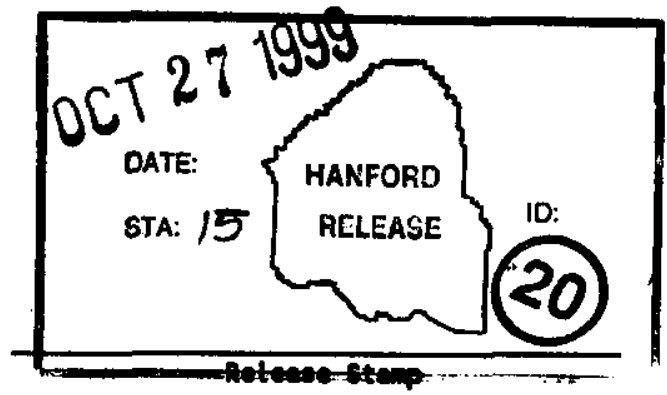

Approved for Public Release 


\title{
DATA REPORT FOR THE INTEGRITY ASSESSMENT REPORT HNF-4589
}

\section{PROJECT W-178 \\ 219-S SECONDARY CONTAINMENT UPGRADE}

\author{
Prepared for \\ Waste Management Hanford \\ Prepared by \\ David S. McShane P.E. \\ Fluor Daniel Northwest
}


The purpose of this document is to compile supporting documentation for the Integrity Assessment Report (HNF 4589) for Tanks 101 and 102 in the 219-S Facility. This approach minimizes the size of the Integrity Assessment Report (IAR) (HNF-4589) and still provide a path to detailed information. This IAR addresses the evaluation of Tanks 101 and 102 and other existing components located in the 219-S Waste Handling Facility. This document includes four appendices as follows:

Appendix A - This appendix contains the qualifications of the Quality Control Inspector.

Appendix $B-$ This appendix lists the procedures used in the inspection. Due to the proprietary nature of the procedures, they are not contained in the appendix. A copy of each procedure is included in the Construction Work Package, CWP No. W-178-04, which is part of the Project W-178 Records.

Appendix $\mathrm{C}$ - This appendix includes the process used to perform the video taping of the inside of the Tanks.

Appendix D - This appendix provides the QC/Engineering evaluation of the Non-destructive examination of Tanks 101 and 102. 
HNF-4621

REV. 0

\section{APPENDIX A}

\section{QUALIFICATIONS OF EXAMINATION PERSONNEL}




\section{TABLE OF CONTENTS}

Quality Assurance Inspector's Resume . . . . . . . . . . . . . . . . . . . . A-3 Quality Assurance Inspector's Certification Resume . . . . . . . . . . . . . . . . A-6 Quality Assurance Inspector's AWS Welding Certificate . . . . . . . . . . . . . . . A-10 Quality Assurance Inspector's NDE Personnel Certification Records . . . . . . . . . . A-11 Quality Assurance Inspector's Inspector Certification Records. . . . . . . . . . . . . A-14 
JERRY A. KIMBALL

\section{EDUCATION}

Columbia Basin College. Pasco. Washington

-Served 4 year Apprenticeship Program

$-Q A / Q C$. NDT, and Welding Inspection

Emery County High School. Huntington. Utah

\section{CERTIFICATIONS}

Level II RT, MT, PT, VT-1. VT-2 per SNT-TC-1A

CWI \#93100551

\section{EXPERIENCE}

$10 / 96$ to Present

Level II: RT PT MT VT

Fluor Daniel Northwest. Inc.

Position: $\quad$ Perform the above disciplines throughout the Hanford Site

$2 / 91$ to $10 / 96 \quad$ Level II: RT PT MT VT ICF-KH Hanford

Position: $\quad$ Perform the above disciplines throughout the Hanford site.

$6 / 87$ to $12 / 91$ Level II: RT. PT

C.T.I. Inc. Prudhoe Bay. AK

Position: $\quad$ Supervisor over Real Time Radiography Inspection of Flowlines and Common Lines at Prudhoe Bay. My job consisted of putting all the data from the field into a computer and doing all the analysis on the corrosion and turning all the information over to ARCO.

1/87 to 6/87 Level II: VT-1. VT-2, RT, MT, PT

UNC Nuclear Industries, Richland. WA

Position: $\quad$ Performed Quality Assurance/Quality Control in-service inspections of hangers. supports. restraints. snubbers. structurai bolting with weld inspection and hydraulic and pneumatic iesting of piping systems and pressure vessels per ASME Section XI during the outage of the nuclear power plant. 
Jerry A. Kimbal1

Resume/2

4/86 to $10 / 86$ Level II: RT, PT, VT

Tri-Testing. Richland, WA

Position: Performed LEVEL II RT, PT and VT on-site at nuclear reactors in Idaho Falls. ID. Also consisted of pipelines and tank jobs. work was performed to API and ASME Codes.

$7 / 85$ to $4 / 86$ MT, PT. VT, RT, and UT Examinations

Morrison Knudsen Company. Inc.

Position: $\quad$ At Vermont Yankee Nuclear Power Plant. Brattleboro. VT. Performed NDE/QC examinations that included MT. PT. VT. RT, and UT thickness on reactor recirculation pipe replacement outage.

1/85 to 7/85 Level II: RT

Butler Service Group (For ITT Grinnel), Braintree. MA

Position: $\quad$ At Nine Nile Point. Lycoming. NY. Performed LEVEL II RT PreService Inspection of nuclear pipe welds in accordance with ANSI.B31.1 and ASME codes.

4/84 to $11 / 84$ LEVEL II: PT, MT. RT. Per SNT-TC-1A.

Bestco, 2939 Park Drive, Richland. WA

Position: $\quad$ At Union Carbide Silicon Plant. Moses Lake. WA. Performed Isotope Radiography and Liquid penetrant testing. Additional duties included Borescoping with photography. assisting in welder qualification testing. locating welds and determining Inspection Requirements, directed weld repair and coordinated off shift radiography. Assisted in preparing I/F Planner packages and installation for final systems turnover and testing.

2/84 to $3 / 84$ LEVEL II: RT and UT TRAINEE Anvil Corporation, Bellingham. WA

Position: At Alaskan Module Project. Anacortes. WA. Performed Isotope Radiography and assisted LEVEL II UT personnel in inspection of full penetration welds. ASME SEC III and SEC $V$.

12/81 to $9 / 83$ NDE TECHNICIAN: LEVEL II PT, MT, \& LEVEL I RT per SNT-TC - $1 A$. Bestco. 2939 Park Drive, Richland. WA

Position: $\quad$ Performed Inspection from on-site Lab at WPPSS No. 2 Nuclear Plant. Hanford WA. Assisted in weld repair. final system documentation and installation turnover. Work was performed to 
ASME III. ASME V. ASME IX. ANSI b31.1, AWS D-1.1.

Jerry A. Kimba11

Resume/3

$12 / 80$ to $7 / 81$ WELDER:

HUICO. Inc., Boise, ID

Position: Qualified and welded utilizing the following welding procedures

$3 / 79$ to $5 / 80$ NDE TECHNICIAN up to $2 "$ thickness, SMAW, GMAW, FCAW. SAW, GTAW.

Nix Testing, Inc., Richland, WA

Position: $\quad$ From the on-site NDE Lab at WPPSS Plant No. 2. Hanford. WA. Performed NDE Inspection on installations of the primary structure and internal piping of the plant. Assisted in complling records for final systems turnover. Work was performed to ASME III. ASME V. ASME IX. ANSI B31.1. AWS D-1.1.

The above Educational Background. Training Record and Employment History are true to the best of my recollection and knowledge. 


\section{CERTIFICATION RESUME}

Jerry A. Kimball

Fluor Daniel Northwest

17002

\section{EDUCATION}

- Emery County High School, Castledale, Utah

- Columbia Basin College, Pasco, Washington

- Plumbers \& Steamfitters Local 598 Apprenticeship Program

- CWI \#93100551

\section{TECHNICAL COURSES}

- Local 598 Apprenticeship Program

Radiography

Liquid Penetrant

MagParticle

Ultrasonic

EddyCurrent

Visual Inspection . -

Radiation Safety
200 Hours

12 Hours

20 Hours

80 Hours

80 Hours

40 Hours

40 Hours

\section{EXPERIENCE}

- Fluor Daniel Northwest, Inc.

Richland, WA

October 1996 to

Present

Concrete Testing

Weld Inspection

Pressure Testing

Coatings

Hilti Bolts

- ICF Kaiser Engineers Hanford Co.

Richland, WA

December 1991 to

September 1996

Concrete Testing

6 months

Weld Inspection

12 months

Pressure Testing

12 months

Coatings

6 months

Hilti Bolts

6 months 
Certification Resume

Jerry A. Kimball/2

- Kaiser Engineers Hanford Co. (Contd.)

NDE

Fluorescent Penetrant Testing

RT Radiography

PT Liquid Penetrant

MT MagParticle

UT Ultrasonic (Thickness)

1 month

12 months

12 months

12 months

3 months

- C.T.I., Inc.

June 1987 to

Anchorage, Alaska

December 1991

Pressure Testing

6 months

Welding Visual

3 months

Coating

Structural Welding

4 months

6 months

\section{NDE}

RT Radiography

PT Liquid Penetrant

MT MagParticle

UT Ultrasonic (Thickness)

36 months

6 months

6 months

12 months

- UNC Nuclear Ind.

January 1987 to

Richland, WA

June 1987

Hilti Bolts

3 months

Pressure Testing

Mechanical (Piping and Vessels)

Welding Visual

Structural Welding

3 months

3 months

3 months

3 months

NDE

RT Radiography

3 months

General

VT Visual Weld

3 months 


\section{Certification Resume}

Jerry A. Kimball/3

- Tri-Testing

April 1986 to

Richland, WA

October 1986

NDE

RT Radiography

5 months

MT MagParticle

3 months

PT Liquid Penetrant

3 months

- Morrison Knudsen

July 1985 to

Cleveland, $\mathrm{OH}$

April 1986

NDE

RT Radiography

8 months

PT Liquid Penetrant

2 months

General

VT Visual Weld

3 months

VT Structural

3 months

- Butler Services Group

Braintree, MA

January 1985 to

July 1985

NDE

RT Radiography

PT Liquid Penetrant

MT MagParticle

- Anvil Corporation

Bellingham, WA

6 months

2 months

2 months

February 1984 to

March 1984

NDE

RT Radiography

2 months

- Bestco Services Group

Richland, WA

December 1981 to to September 1983

NDE

RT Radiography

PT Liquid Penetrant

10 months

6 months

MT MagParticle

8 months

UT Ultrasonic

2 months 


\section{Certification Resume}

Jerry A. Kimball/4

- Huico, Inc.

Boise, ID

Other

Welder

- Nix Testing

Richland, WA

NDE

RT Radiography

PT Liquid Penetrant

MT MagParticle

UT Ultrasonic
December 1980 to

July 1981

8 months

March 1979 to

May 1980

6 months

3 months

3 months

3 months 

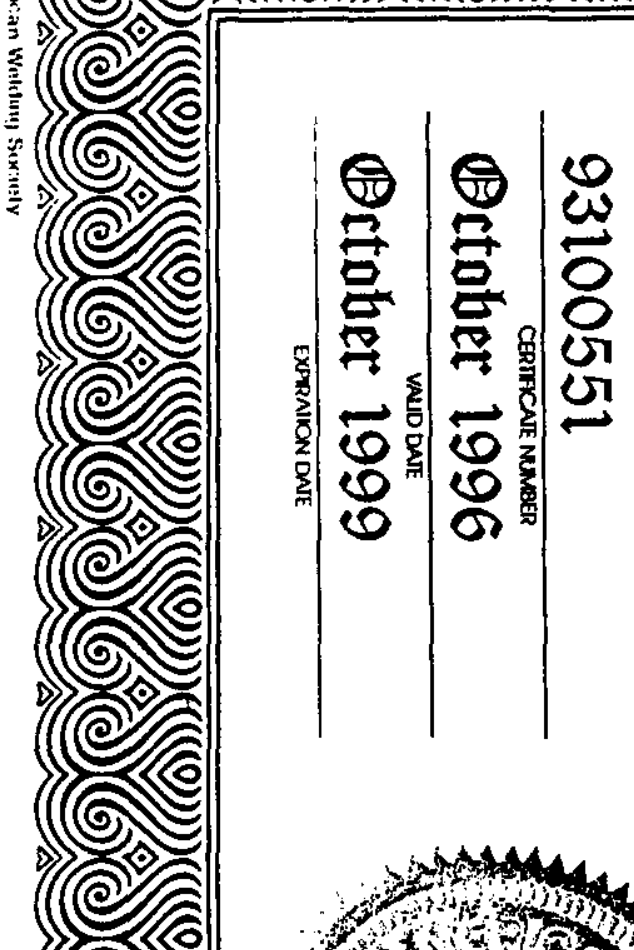

(6)
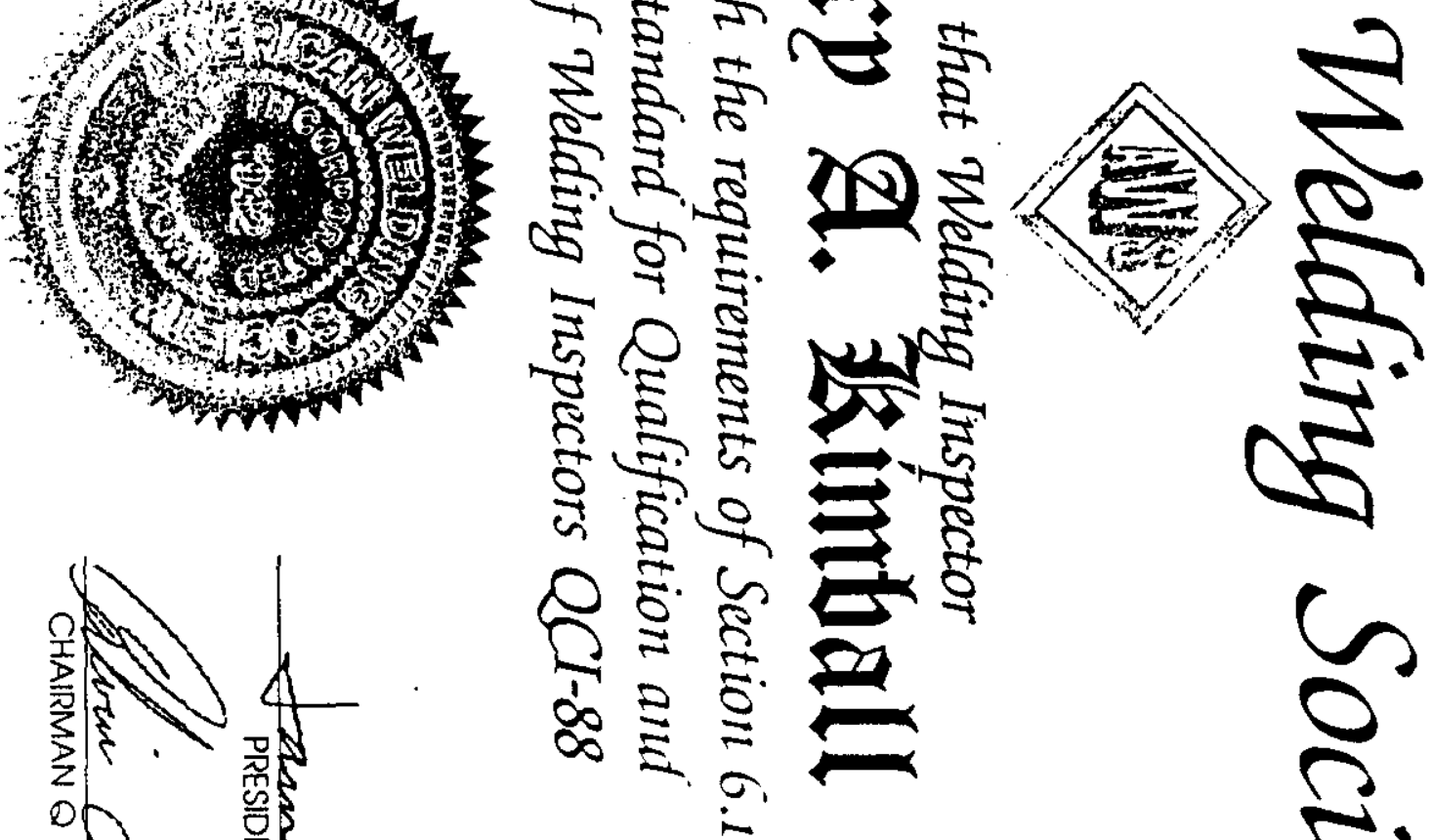

oh

品 可
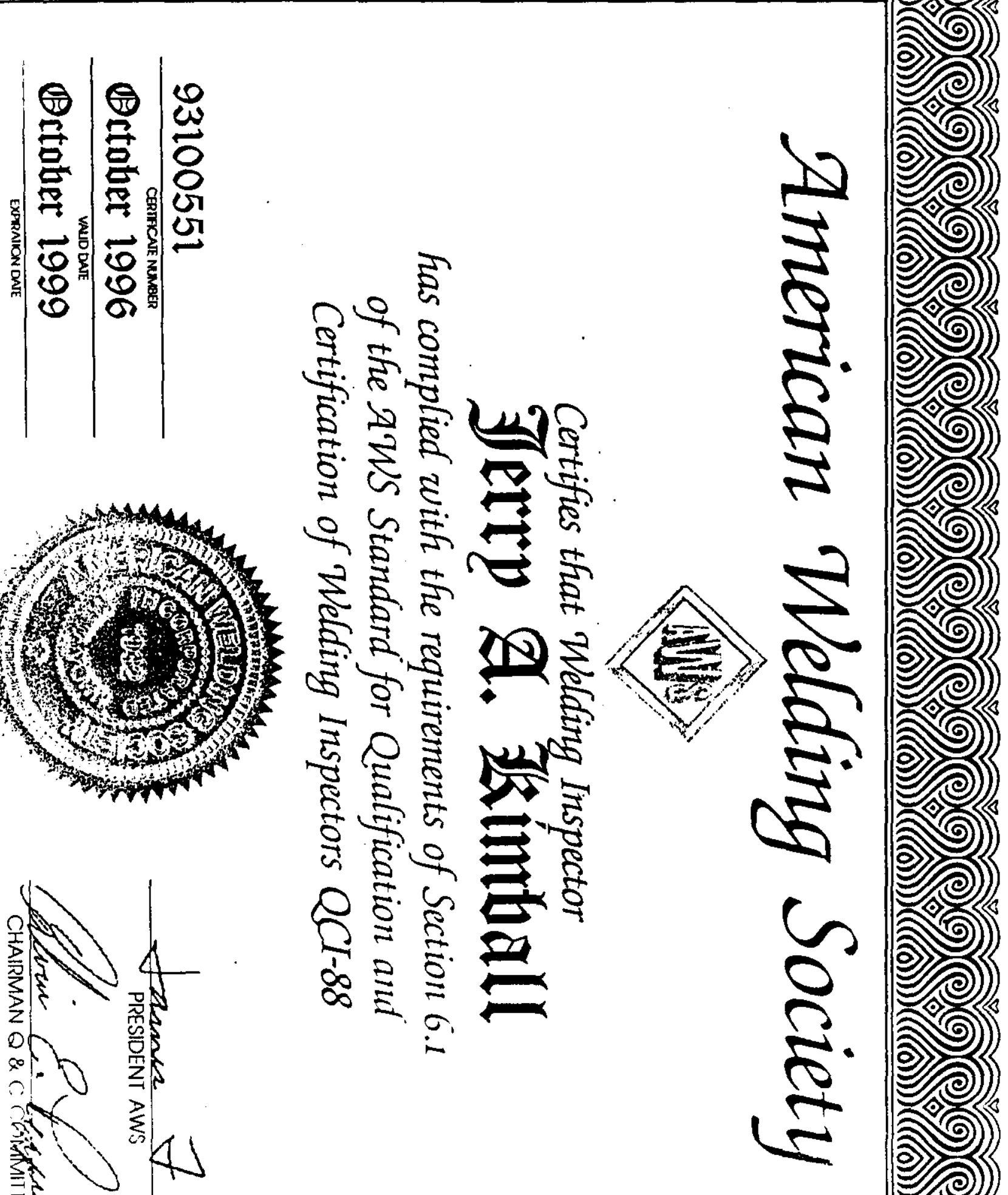

(2)
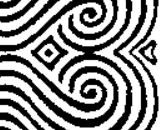

3
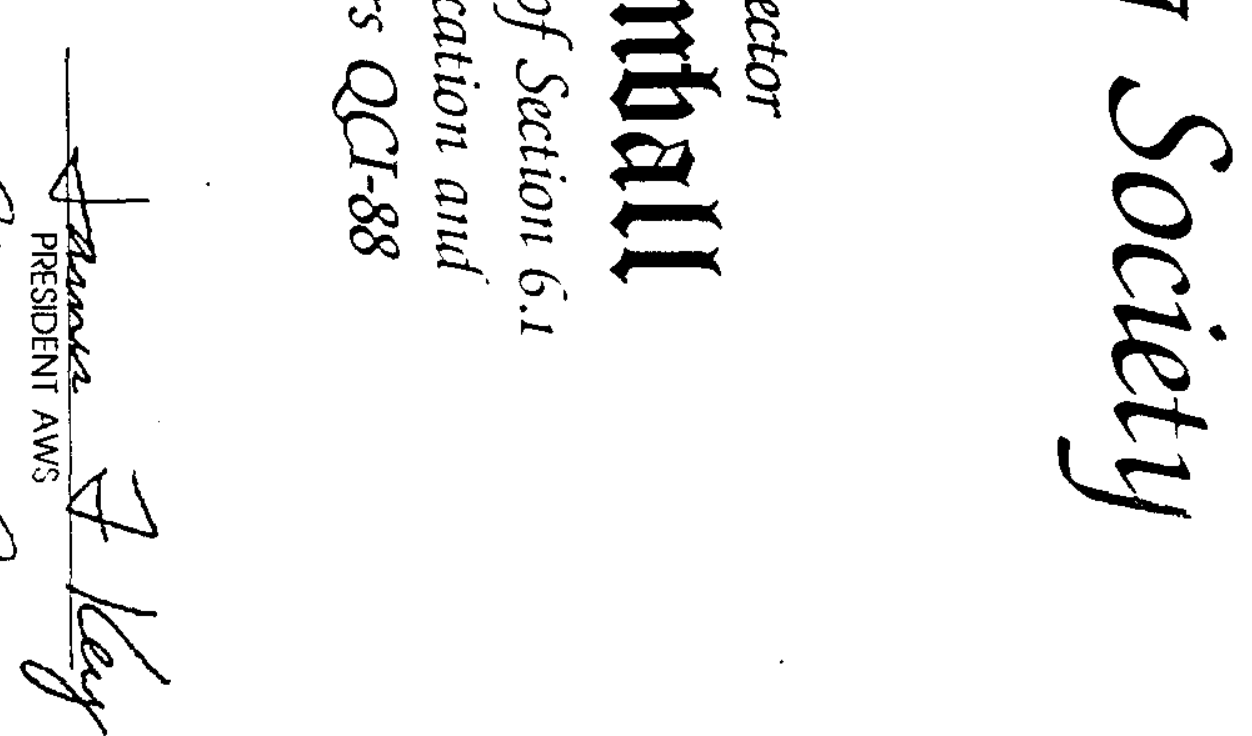

$$
\text { (1) }
$$

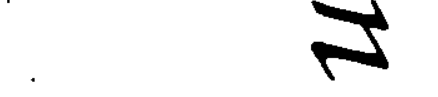




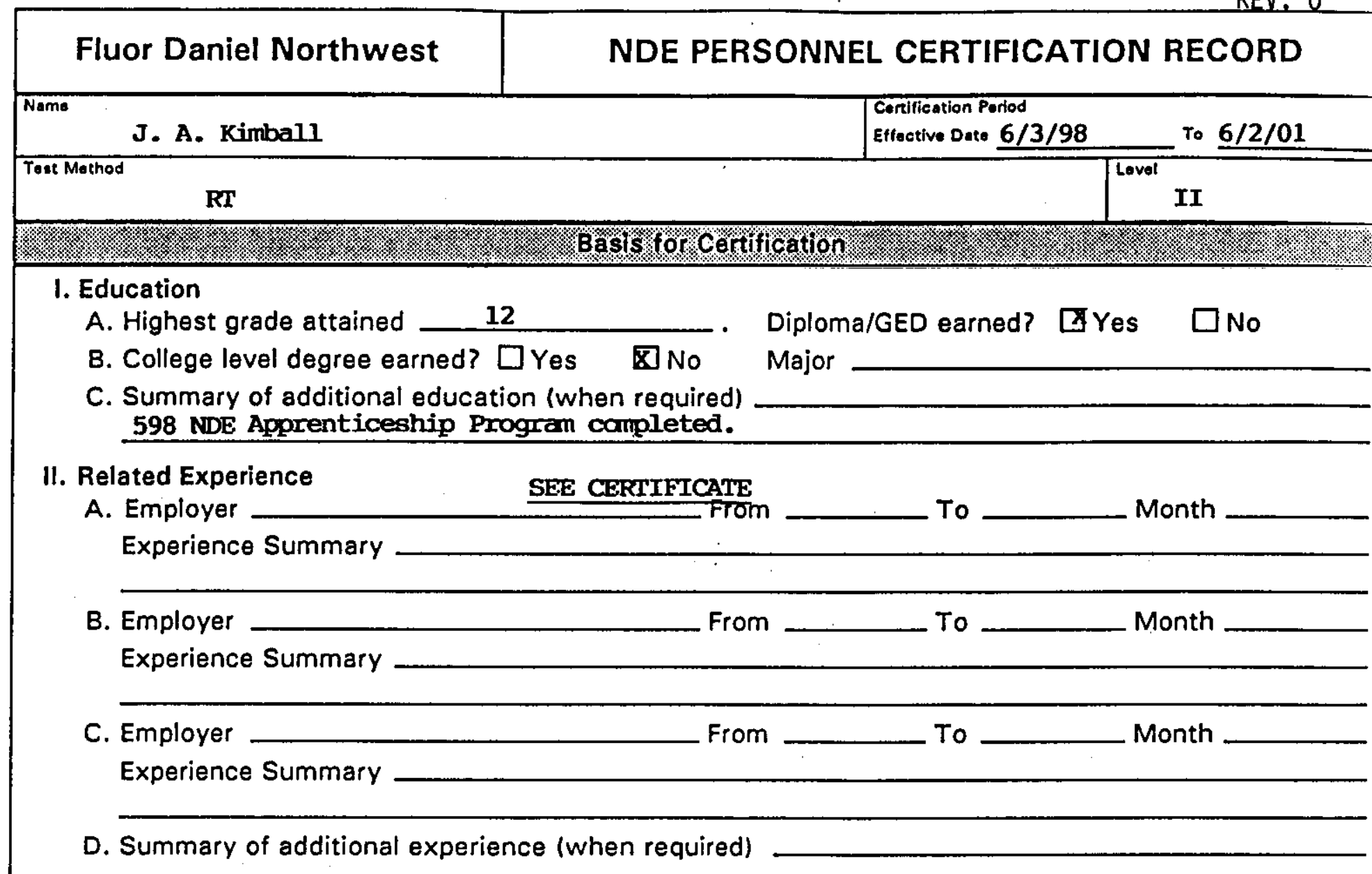

III. Indoctrination/Training
A. General indoctrination complete?
团 Yes
B. A
C. Additional training complete when required?
XYes
D. Summary of additional training (when required)

IV. Test Results:
A. Type
Grade
1. General
2. Specific
3. Practical
4. Composite

$$
\begin{aligned}
& 90 \\
& \hline 90 \\
& \hline 98 \\
& \hline
\end{aligned}
$$$$
93.28
$$

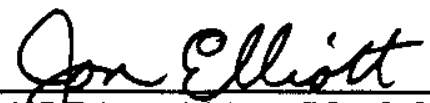

NoE Level III or ESH\& Q Manager
V. Eye exam results acceptable for:

\ASME Sec. III $\$ SNT-TC-1A/ASME NQA-1 VI. Physically capable of performing assigned tasks:

囚Acceptable

Remarks

Recertification

Basis for recertification

Recertified: $\square$ Yes $\square$ No

Certification Period: From To 


\section{Fluor Daniel Northwest} Name

$$
\text { J-A. Ken BndL }
$$

LQQUTO TENETRAT

Taet Method

\section{NDE PERSONNEL CERTIFICATION RECORD}

Basis tor certification

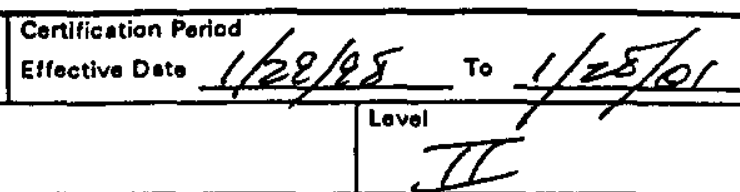

Cerlification Poriod

ive Dete II

1. Education
A. Highest grade attained
12
B. College level degree earned? $\square$ Yes $\square$ No
Diploma/GED earned? \&Yes
$\square$ No
C. Summary of additional education (when required)
Major

II. Related Experience

A. Employer FDNW

Experience summary SEE RescemE

From $10 / 96$ - Tosed Month 12

B. Employer /SEH

Experience Summary

SEE RESOME From

C. Employer

From To Month

Experience Summary

D. Summary of additional experience (when required)

III. Indoctrination/Training
A. General indoctrination complete?
B. Required training, including that specified in Attachment TC 8-C, complete?
C. Additional training complete when required?
区Yes
XYes
D. Summary of additional training (when required)
DYes \&N/A

IV. Test Results:

A. Type

1. General

Grade

2. Specific

96.7

3. Practical

4. Composite

86.67

Q3

$92 \cdot 12$
V. Eye exam results acceptable for:

\ASME Sec. III

இSNT-TC-1A/ASME NOA-1

VI. Physically capable of performing assigned tasks:

8 Acceptable

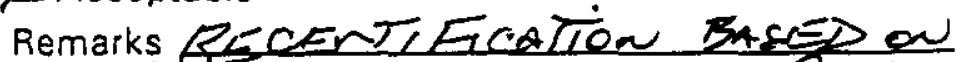

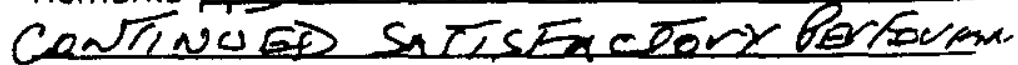

PUELIOOS LEVEH TL

$$
\text { NDE Level III or ESH\&O Manager }
$$

\section{Date}

NDE Assignment Date

Recertification

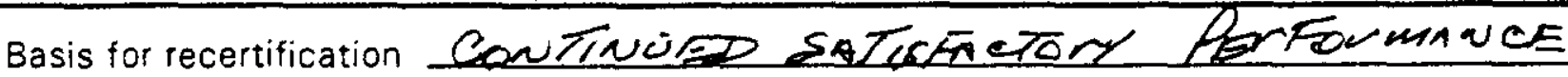

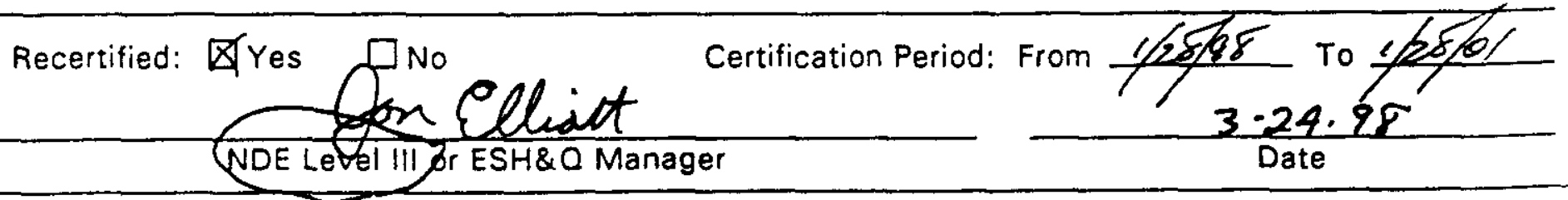


Fluor Daniel Northwest

NDE PERSONNEL CERTIFICATION RECORD

Nama

KImBal/ TA

MAGNETTC PARTICLE

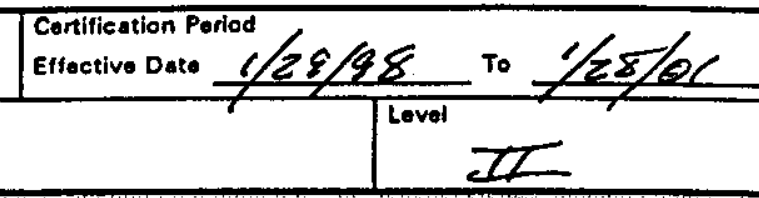

Basis for Certification

1. Education
A. Highest grade attained 12
Diploma/GED earned? $\triangle$ Yes $\square$ No
B. College level degree earned? $\square$ Yes $\square$ No Major
C. Summary of additional education (when required)

II. Related Experience
A. Employer
EDN $\omega$ Experience Summary SEERESOME
From $19 / 26$ To ResenT Month

B. Employer

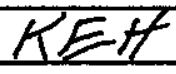

Experience Summary

From SEE RESCOME $1 / 95$ To $8 / 86$ Month 20

C. Employer From To Month

Experience Summary

D. Summary of additional experience (when required)

III. Indoctrination/Training
A. General indoctrination complete?
凶Yes
B. Required training, i sterifted ?
甘Yes
C. Additional training complete when required?
$\square$ Yes
区 $/ A$
D. Summary of additional training (when required)

IV. Test Results:
A. Type
Grade
1. General
93.3
2. Specific
100
3. Practical 100
4. Composite $\frac{q 7.7 ?}{9}$

V. Eye exam results acceptable for:

\ASME Sec. III

$\not J$ SNT-TC-1A/ASME NOA-1
A Acceptable

Remarks BEAENTFCaTION ZASSP ON contivued stlisfue Tory Rerarmancs

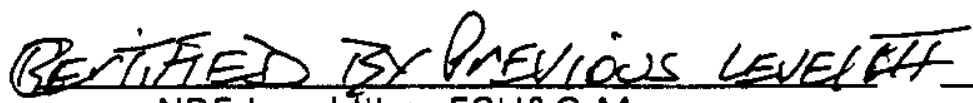
NDE Level III or ESH\&O Manager
SA

NDE Assignment Date

Recertification

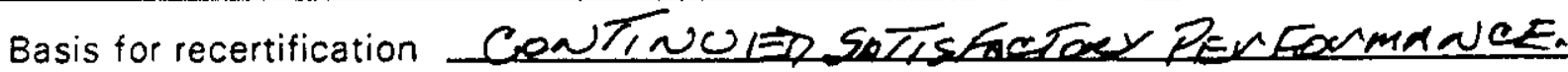

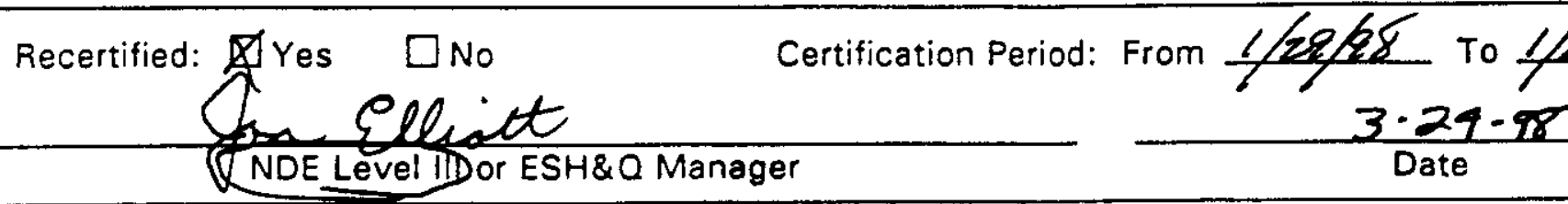




\section{INSPECTOR CERTIFICATION RECORD}

\section{Name}

\section{KImBAII T.A.}

Discipline Certified

\section{Education}
A. Highest grade attained
12
B. College level degree earned? $\square$ Yes $\square$ No
Diploma/GED earned? \& Y Yes $\square$ No
C. Summary of additional education (when required)
Major

II. Related Experience
A. Employer
FDNW
Experience Summary SEE RESCUME
From $10 / 96$ To Presen/T Total Months 17

B. Employer_tcEt

Experience Summary SEE RESCUNE $\frac{\text { Level }}{\text { Lt }}$ $3 / 1 / 21$ (1)

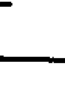




\section{INSPECTOR CERTIFICATION RECORD}

Name

TERRYA.KImBAII

Certification Period

Discipline Certified

C.3 structurnl

Basis for Certification

Effective Date Rox 211997 To Lex 26 200:

Level I

\section{Education}
A. Highest grade attained
12

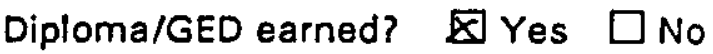
B. College level degree earned? $\square$ Yes $\square$ No
Major
C. Summary of additional education (when required)

II. Related Experience
A. Employer CTI ZNC
From $2-q$
To $|2-4|$
Total Months kmo
Experience Summary SEE RESUME.
B. Employer UNC NUCLER IND From 1-87 To $18-87$ Total Months 3 mo Experience Summary SEE RESUME
C. Employer Tel-TEsTinic From $4-86$ To 10-86 Total Months $3 m 0$ Experience Summary___ SELE RESumE

D. Summary of additional experience (when required)

III. Indoctrination/Training
A. General indoctrination complete?
$\triangle$ Yes
B. Required training complete?
区Yes
C. Additional training complete when required?
$\square$ Yes
D. Summary of additional training (when required)

IV. Written Test,

$$
\underset{\text { or }}{\operatorname{Grade}} 15 \%
$$

V. Capability Demonstration, Grade $\alpha A$

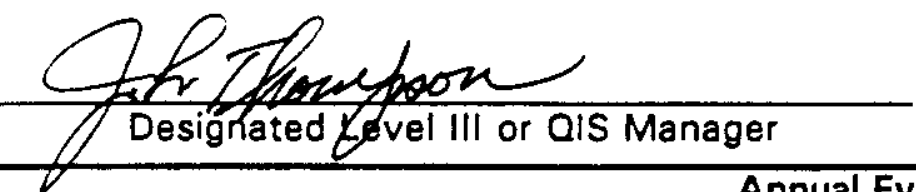

First Evaluation

Acceptable $\square$ Unacceptable

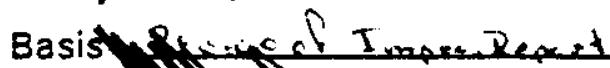

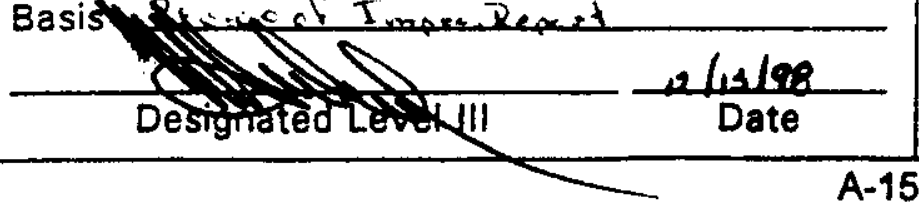

VI. Eye Exam Results:

D Acceptable

VII. Physically capable of performing assigned tasks: \ Acceptable Remarks

\section{Qet 271997}

\section{Date}

Annual Evaluation
Second Evaluation

Acceptable $\quad \square$ Unacceptable

Basis 
Fluor Daniel Northwest

INSPECTOR CERTIFICATION RECORD

Name

J. A. Kimbal1

Discipline Certified

GENERAL: G1 Visual Weld

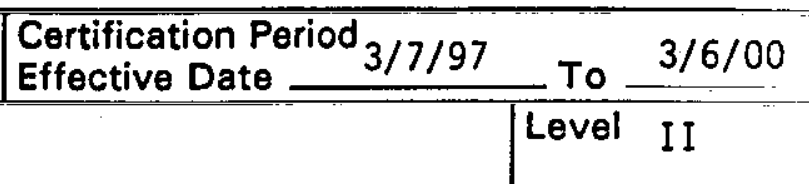

\section{Basis for Certification}

I. Education
A. Highest grade attained.
12
B. College level degree earned? $\square$ Yes $\square$ No
Diploma/GED earned? $\square$ Yes $\square$ No
C. Summary of additional education (when required)
Major

II. Related Experience
A. Employer ICF/KH/FDNW
From 12/91 To Present
Total Months
Experience Summary See resume

B. Employer From To Total Months Experience Summary

C. Employer From To Total Months

\section{Experience Summary}

D. Summary of additional experience (when required) current AWS certified welding inspector

III. Indoctrination/Training
A. General indoctrination complete?
$\square$ Yes
B. Required training complete?
C. Additional training complete when required?
QYes
D. Summary of additional training (when required)
$\square$ Yes $\square$ N/A

\section{Written Test,}

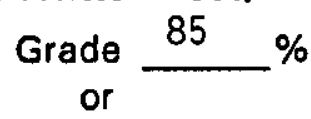

V. Capability Demonstration, Grade N/A \%

GENTIFIED BYPREVIOOS LEVEl IIT

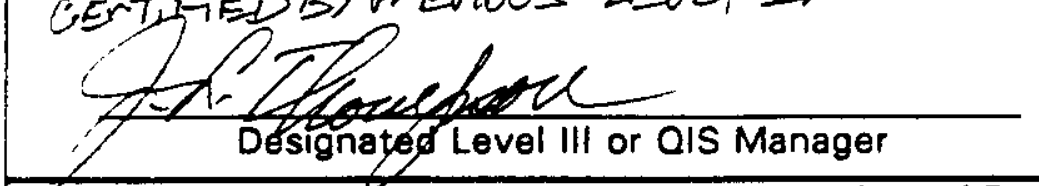

V1. Eye Exam Results:

X Acceptable

VII. Physically capable of performing assigned tasks: * Acceptable

Remarks

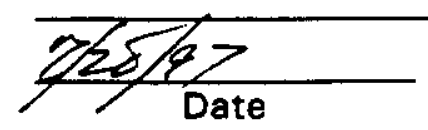

Annual Evaluation

\section{First Evaluation}

Acceptable $\square$ Unacceptable

Basis

Designated Level III 


\section{Basis for Certification}

\section{Education}
A. Highest grade attained
12
B. College level degree earned? $\square$ Yes $\square$ No
Diploma/GED earned? $\square$ Yes $\square$ No
C. Summary of additional education (when required)
Major

\section{Related Experience}
A. Employer ICF Kaiser Hanford
From $12 / 91$ Experience Summary Performs inspections of anchor bolts installations

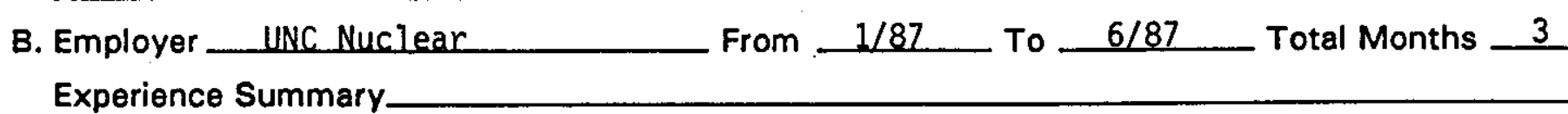

C. Employer From To

\section{Experience Summary}

D. Summary of additional experience (when required)

III. Indoctrination/Training
A. General indoctrination complete?
B. Required training complete?
C. Additional training complete when required?
Y Yes
Yes
$\square$ Yes
D. Summary of additional training (when required)

\section{Written Test,}

$$
\text { Grade } \underset{\text { or }}{85} \%
$$

V. Capability Demonstration, Grade N/A \% CEETIFIED BY Previdus LEVEl FF

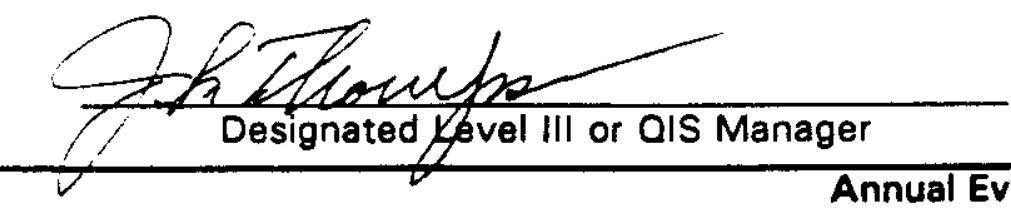

\section{First Evaluation}

Acceptable $\square$ Unacceptable Basis

VI. Eye Exam Results:

$\square$ Acceptable

VII. Physically capable of performing assigned tasks: $\triangle$ Acceptable

Remarks

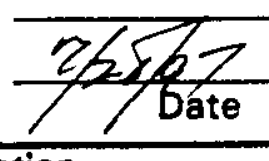

\section{Total Months \\ Present Total Months $3+$ $+$}


Fluor Daniel Northwest

INSPECTOR CERTIFICATION RECORD REV. 0

Name

$\frac{\text { J.A. Kimball } 1}{\text { Discipline Certified }}$

Certification Period

G2-UTtrasonic Thickness Measurement

Effective Date $6 / 9 / 97$ To $6 / 8 / 00$

Basis for Certification

I. Education
A. Highest grade attained
12
B. College level degree earned? $\square$ Yes 4 No
Diploma/GED earned? $\square$ Yes $\square$ No
C. Summary of additional education (when required)
Major

\section{Related Experience} A. Employer $\frac{\text { KEH/ICFKH/FDNW }}{\text { From } 2 \text { see resume }}$ To $\frac{12 / 91}{\text { present }}$ Total Months Experience Summary
B. Employer C.I.T. From $6 / 87$ To
$12 / 91$ Total Months
C. Employer Bestco Services
Experience Summary see resume see resume

D. Summary of additional experience (when required)

3 months - see resume

III. Indoctrination/Training
A. General indoctrination complete?
B. Required training complete?
C. Additional training complete when required?
ג Yes
d] Yes
$\square$ Yes
N/A
$D$. Summary of additional training (when required)

IV. Written Test,

$$
\underset{\text { or }}{\text { Grade }} \text { N/A } \%
$$

V. Capability Demonstration, Grade $98 \%$

CENTISED BY Previous heVEL DI

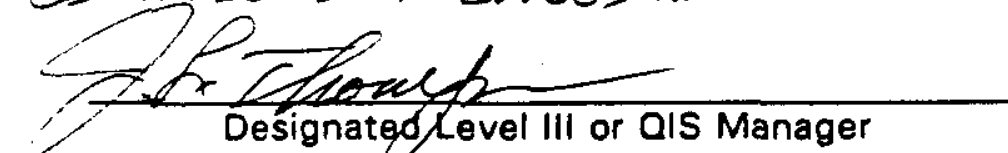

VI. Eye Exam Results:

$凶$ Acceptable

VII. Physically capable of performing assigned tasks: X] Acceptable

Remarks

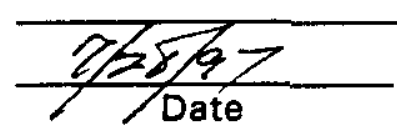

Annual Evaluation

\section{First Evaluation}
Acceptable
$\square$ Unacceptable

Second Evaluation
Acceptable
$\square$ Unacceptable 
Fluor Daniel Northwest

\section{INSPECTOR CERTIFICATION RECORD}

\begin{tabular}{|c|c|c|c|}
\hline Name $\mathrm{Kim} \mathrm{B}_{\mathrm{H}} \mathrm{ll}$ & $\pi A$. & $\begin{array}{l}\text { Certification Period } / 1 / 98 \\
\text { Effective Date } 3 / 1 / 4\end{array}$ & To $3 / 1 / 2$ \\
\hline $\begin{array}{r}\text { Discipline Certified } \\
\text { m } 3\end{array}$ & REESURE TESTINTS & & $\frac{\text { Level }}{I L}$ \\
\hline
\end{tabular}

I. Education
A. Highest grade attained
12
B. College level degree earned? $\square$ Yes $\$$ No
Diploma/GED earned? \&Yes $\square$ No
C. Summary of additional education (when required)
Major

II. Related Experience
A. Employer
EDNW
From $10 / 1 / 96$ To ALESET Total Months
Experience Summary
B. Employer KEAf
From $12 / 91$ To $\frac{9 / 96}{6}$
Experience Summary
C. Employer
From
To
Total Months

\section{Experience Summary}

Total Months lo3

D. Summary of additional experience (when required)

111. Indoctrination/Training
A. General indoctrination complete?
B. Required training complete?
C. Additional training complete when required?
\Yes
区 Yes
$\square$ Yes
E) N/A
D. Summary of additional training (when required)

IV. Written Test,
Grade
$90 \%$
or

V. Capability Demonstration,

Grade $N / A \%$

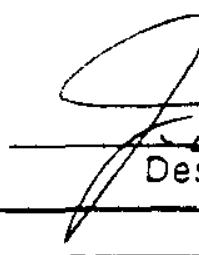

\section{Design}

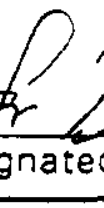

First Evaluation

$\triangle$ Asceptable easis Givinuel' Acceprable Defor matce

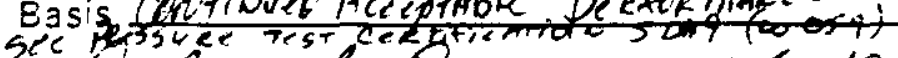

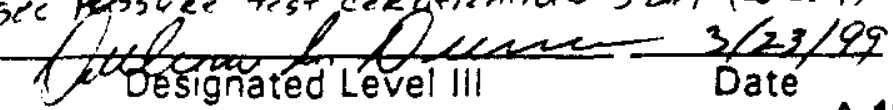
A-19
VI. Eye Exam Results:

A Acceptable

Vil. Physically capable of performing assigned tastis ¿ Acceptable Remarks RECENTIFETTON BAEED

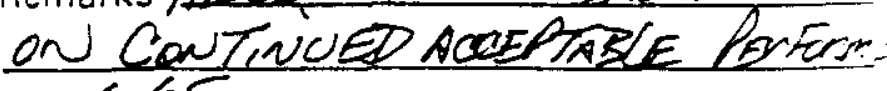
$3 / 1 / \frac{8}{\text { Date }}$

Annual Evaluation
Second Evaluation
$\square$ Acceptable
$\square$ Unacceptable

Basis 
Fluor Daniel Northwest

\section{INSPECTOR CERTIFICATION RECORD}

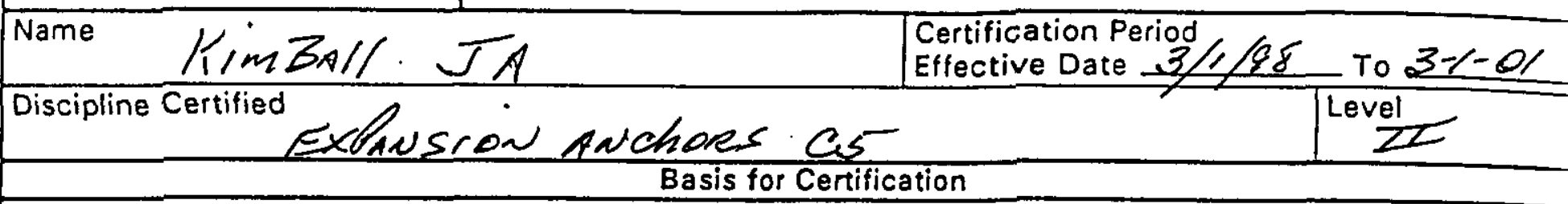

1. Education
A. Highest grade attained _ 12
B. College level degree earned? $\square$ Yes $\square$ No
Diploma/GED earned? \Yes $\square$ No
C. Summary of additional education (when required)
Major

II. Related Experience
A. Employer FDNU Experience Summary SEE lLESCME
From 10 G6 To Resar Total Months

B. Employer $1 / 5 A 4$
Experience Summary
C. Employer
From To Total Months

\section{Experience Summary}

D. Summary of additional experience (when required)

III. Indoctrination/Training
A. General indoctrination complete?
B. Required training complete?
C. Additional training complete when required?
D. Summary of additional training (when required)

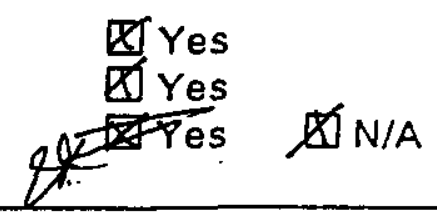

IV. Written Test,

Wrade $85 \%$ WNaTh/

V. Capability Demonstration,

Grade $\%$
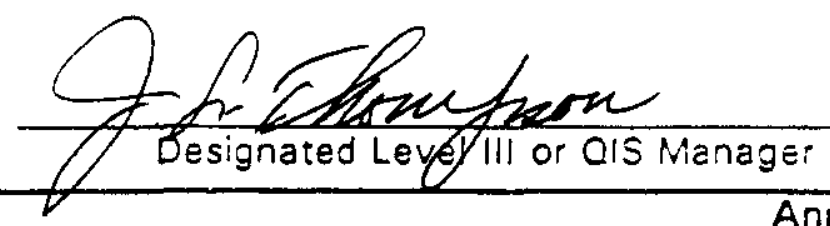

\section{Annual Evaluation}

\section{First Evaluation}

Acceptable

$\square$ Unacceptable

Basis
Second Evaluation

Acceptable $\square$ Unacceptable

Basis
[] Acceptable

Remarks BECECTIFCHTion BSSD D.

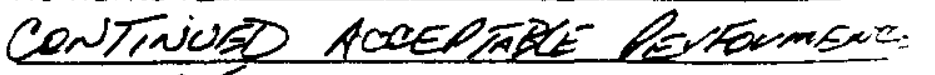

$$
\text { Date }
$$


FLUOR DANIEL NORTHWEST PROCEDURES FOR NON-DESTRUCTIVE EXAMINATION

\section{REFERENCE LIST}

Practice 134500 8104, Publication Date September 08, 1997

"FUNCTIONAL CHECKING OF MEASURING AND TEST EQUIPMENT"

Practice 134500 8225, Publication Date September 08, 1997

"MATERIAL THICKNESS MEASUREMENTS"

Practice 134500 8351, Publication Date July 15, 1998

"CONTROL OF MEASURING AND TEST EQUIPMENT"

Practice 134511 1005, Publication Date January 12, 1998

"VISUAL EXAMINATION OF WELDMENTS"

The procedures listed here are proprietary. Copies are available in the Construction Work Package CWP No. W-178-04 which is included in the project files for Project W-178 "219-S Secondary

Containment Upgrade" 
HNF-4621

REV. 0

\section{APPENDIX C}

PROCESS FOR PERFORMING INTERNAL VISUAL INSPECTION USING A VIDEO CAMERA

C-i 


\subsection{PROCESS}

2.1 General Description . . . . . . . . . . . . . . . . . . . . . . . . C-1

2.2 Camera . . . . . . . . . . . . . . . . . . . . . . . . . . . . C-1

2.3 Index Tapes. . . . . . . . . . . . . . . . . . . . . . . . . . . C-1

2.4 Monitor Tapes . . . . . . . . . . . . . . . . . . . . . . . . . . C-2

\section{FIGURES}

FIGURE C1, Graphic Description of Camera at Position \#1 . . . . . . . . . . . . . C-3

FIGURE C2, Graphic Description of Camera at Position \#3 . . . . . . . . . . . . . C-4

FIGURE C3, Formulas for Determining Outside Position from Pan and Tilt Angle

Position \#1 \& \#3 of Camera - Tank Quadrants 1 \& 2 . . . . . . . . . . . . . . C-5

FIGURE C4, Formulas for Determining Outside Position from Pan and Tilt Angle

Position \#1 \& \#3 of Camera - Tank Quadrants 3 \& 4 . . . . . . . . . . . . . C-6 


\subsection{SCOPE}

The purpose of this Appendix is to describe the process used to perform the internal inspection of Tanks 101 and 102. A video system was used to inspect the inside of the tanks, since the radiation levels in the tanks were too high to allow a manned entry. The video inspection was taped and copies of those tapes are available in the 222-S facility regulatory file.

\subsection{PROCESS}

\subsection{General Description}

Each tank was video taped from two positions (Position 1 and Position 3 - See Figures C-1 and C-2). This was done to ensure that all positions on the inside of the tank have been video taped. In addition video taping from two positions can provide an additional view of any possible defects in the tank. These tapes are labeled as INDEX tapes and are the primary tapes used for additional inspections. Index tapes 1 and 2 are for Tank 101 and index tapes 3 and 4 are for Tank 102.

The camera was equipped with instrumentation that enabled an internal location to be determined on the outside of the tank. The data recorded, from the camera, were the pan (horizontal angle) and the tilt (vertical angle). This information could be converted to a distance from the longitudinal and top circumfriential weld on the tank. The pan and tilt information was recorded on another set of tapes. These tapes are labeled as MONITOR tapes and have corresponding numbers to the index tapes (i.e. index tape 1 corresponds to monitor tape1 and so forth).

\subsection{Camera}

The camera was installed in a containment that protected the camera from radiological contamination. This containment consisted of a metal cylinder and clear plastic dome. Figures $\mathrm{C} 1$ and $\mathrm{C} 2$ provide a graphical depiction of the viewing area. The containment was equipped with markings which allowed the orientation (pan and tilt) of the camera to be verified during operation. The camera was equipped with a manual 4 to 1 zoom lens. Due to the varying distance from the camera to the tank wall the field of view would change. The shortest distance of the field of view was approximately 4 inches square and the longest distance of the field of view was approximately 16 inches square. Image obtained by the camera was adequate to perform a visual examination.

\subsection{Index Tapes}

The Index tapes provide the primary inspection data. These tapes were made by as follows:

a. The video equipment was on and functionally checked.

b. The camera was rotated to the position shown as 0 degrees (east, see figures C1 and C2)

c. The video index was reset and the video recorder set to record.

d. The pan angle was recorded

e. With out moving the pan the tilt was rotated one monitor frame from top to bottom. Pausing each frame to focus

f. If the operator noticed an area of interest the camera would be centered on the area. If this step occurred the camera was reset to the previous pan and tilt angle prior to continuing.

g. Once at the bottom the camera was move vertically back to the top position.

h. The camera was rotated one monitor frame, the rotation (pan) angle and index number manually recorded. 
i. Steps e through $\mathrm{h}$ were repeated until the entire rotation (pan) of the tank was completed.

\subsection{Monitor Tapes}

Monitor Tapes were made to record the index number from the index tape and the pan and tilt angles all together. This information was necessary in the event that a location from inside the tank was needed to be located on the outside of the tank. Given the Pan and Tilt the position can be determined from formulas in Figures $\mathrm{C}-3$ and $\mathrm{C}-4$ 
FIGURE C-1

REV. 0

GRAPHIC DESCRIPTION FOR CAMERA AT POSITION 1
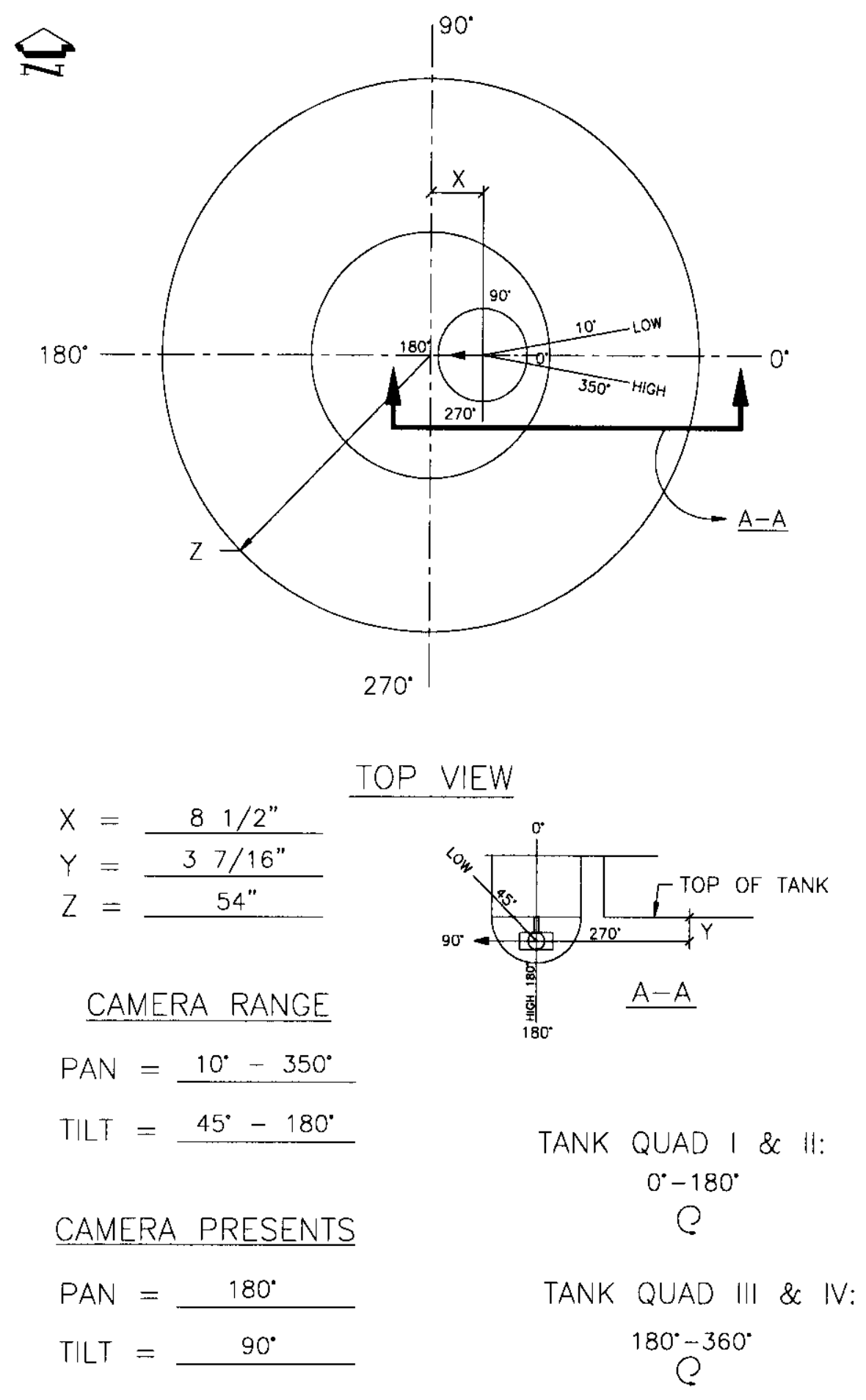

POSITION \#1 


\section{GRAPHIC DESCRIPTION FOR CAMERA AT POSITION 3}

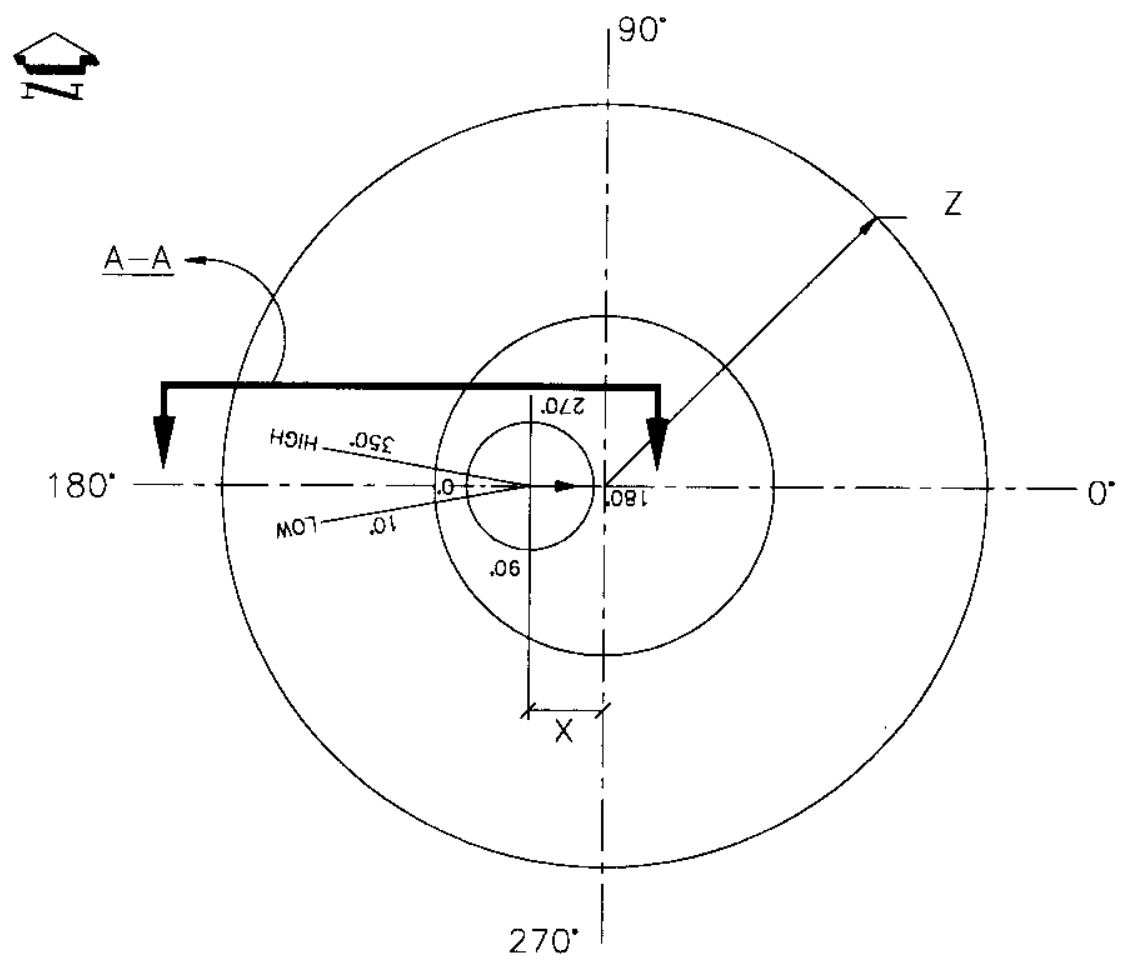

$$
\begin{aligned}
& X=\frac{81 / 2^{\prime \prime}}{37 / 16^{\prime \prime}} \\
& Y=\frac{54^{\prime \prime}}{Z=-.}
\end{aligned}
$$

\section{TOP VIEW}

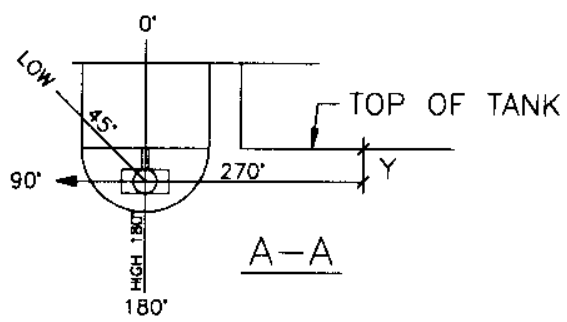

CAMERA RANGE

$$
P A N=10^{\circ}-350^{\circ}
$$

TILT $=45^{\circ}-180^{\circ}$

CAMERA PRESENTS

$$
\begin{gathered}
\text { TANK QUAD | \& II: } \\
180^{\circ}-360^{\circ} \\
?
\end{gathered}
$$

$\begin{aligned} \text { PAN } & =\frac{180^{\circ}}{90^{\circ}} \\ \text { TILT } & =-1\end{aligned}$

TANK QUAD III \& IV: $0^{\circ}-180^{\circ}$

?

\section{POSITION \#3}


FIGURE C-3

FORMULAS FOR DETERMINING OUTSIDE POSITION FROM PAN AND TILT ANGLES

POSITION \#1 \& \#3 - TANK QUADRANTS 1 \& 2

PROBLEM:

FIND THE POSITION ON THE OUTSIDE OF THE TANK FROM THE VIDEOTAPE OF THE INSIDE OF THE TANK.

GIVEN:

$X=5.50^{\prime \prime}$ (DISTANCE FROM CENTER)

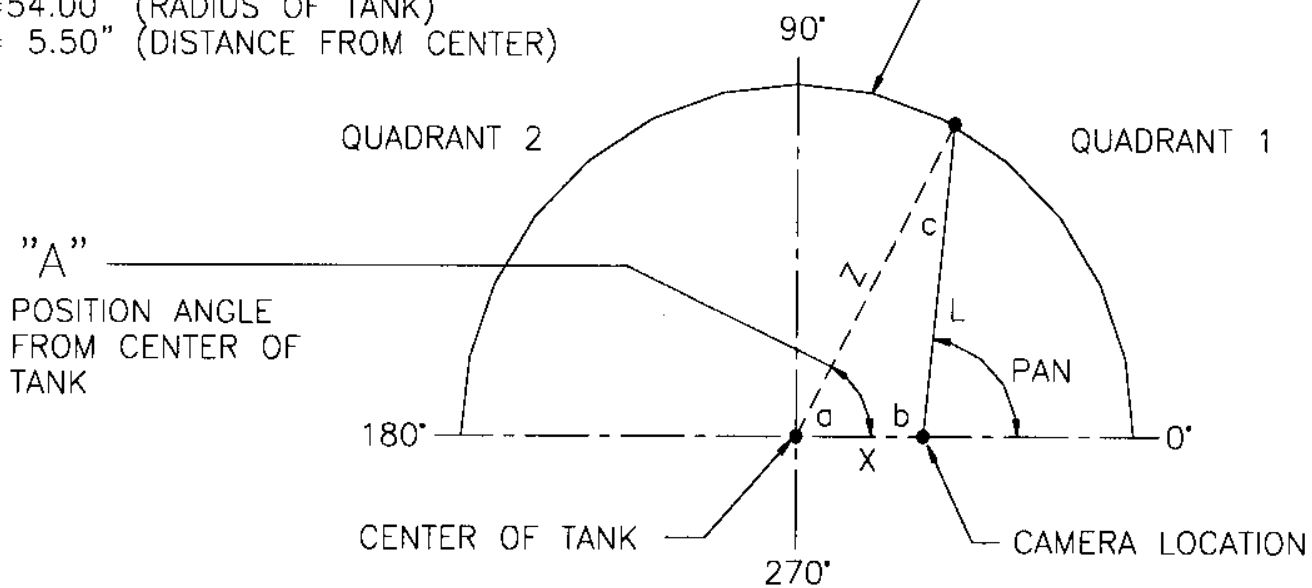

$Y=3.44^{\prime \prime}$ (DISTANCE FROM TOP)

"D"

POSITION FROM TOP

OF TANK

FIND:

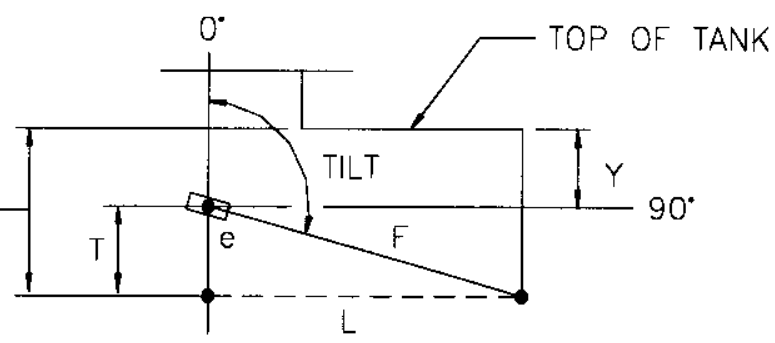

$180^{\circ}$

$b=180-$ PAN $\quad c=\operatorname{SIN}^{-1}\left[\frac{x(\operatorname{SIN~} b)}{Z}\right] \quad a=180-b-c$

POSITION \#1: "A" = a

POSITION \#3: "A" =a+180

$L=\frac{Z(\operatorname{SiN} a)}{\operatorname{SiN} b} \quad e=180-T / L T \quad F=\frac{L(\operatorname{SIN} 90)}{\operatorname{SiN} e} \quad T=\sqrt{e^{2}+L^{2}}$

POSITION \#1 \& \#3: "D"=T+Y 


\section{FORMULAS FOR DETERMINING OUTSIDE POSITION FROM PAN AND TILT ANGLES}

$$
\text { POSITION \#1 \& \#3 - TANK QUADRANTS } 3 \text { \& } 4
$$

\section{PROBLEM:}

FIND THE POSITION ON THE OUTSIDE OF THE TANK FROM THE VIDEOTAPE OF THE INSIDE OF THE TANK.

\section{GIVEN:}

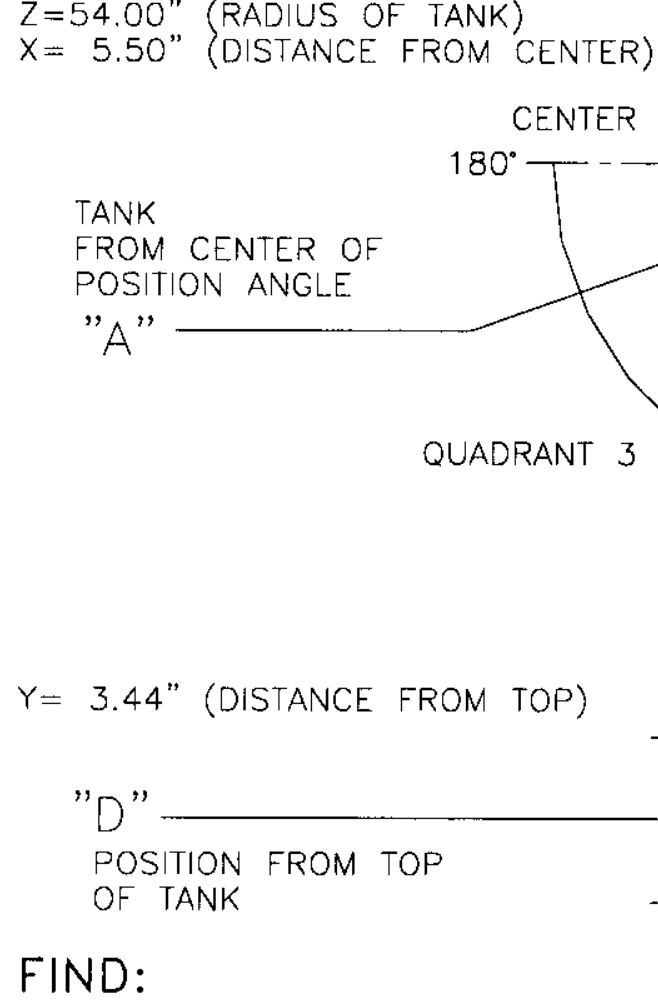

FIND:

FROM CENTER)

$=5.50^{\prime \prime}$ (DISTANCE FROM

$b=$ PAN -180 $c=\operatorname{SIN}^{-1}\left[\frac{x(\operatorname{SIN} b)}{Z}\right]$ $a=180-b-c$

POSITION \#1: $" A "=360-a$

POSITION \#3:

$L=\frac{Z(\operatorname{SIN} a)}{\operatorname{SIN} b}$ $e=180-T H L T$ $F=\frac{L(\operatorname{Sin} 90)}{\operatorname{Sin} e}$ $T=\sqrt{e^{2}+L^{2}}$

POSITION \#1 \& \#3: "D" $=T+Y$ 


\section{APPENDIX D}

\section{EVALUATION OF THE RESULTS OF THE NONDESTRUCTVE}

EXAMINATION OF TANKS 101 AND 102 


\section{TABLE OF CONTENTS}

1.0 SCOPE

2.0 VISUAL EXAMINATION

3.0 ULTRASONIC TESTING

4.0 REFERENCES

D-3

TABLES

TABLE 1, EVALUATION OF INSPECTION DATA BY QUALITY CONTROL AND ENGINEERING . D-3

\section{ATTACHMENTS}

ATTACHMENT 1, INSPECTION REPORT FOR EXTERIOR TANK INSPECTION. . . . . . . . D-4 ATTACHMENT 2, INSPECTION REPORT FOR INTERIOR TANK INSPECTION . . . . . . . . D-5

ATTACHMENT 3, INSPECTION REPORTS FOR ULTRASONIC INSPECTION . . . . . . . D-6

FIGURES

FIGURE 1, POINT A TAPE \#1

FIGURE 2, POINT A TAPE \#2

FIGURE 3, POINT B TAPE \#1

FIGURE 4, POINT B TAPE \#2

FIGURE 5, POINT C TAPE \#1

FIGURE 6, POINT D TAPE \#1.

FIGURE 7, POINT E TAPE \#1

FIGURE 8, POINT F TAPE \#1

FIGURE 9, POINT G TAPE \#1.

FIGURE 10, POINT G TAPE \#2

FIGURE 11, POINT H TAPE \#1

FIGURE 12, POINT H TAPE \#2

FIGURE 13, POINT J TAPE \#1.

FIGURE 14, POINT J TAPE \#2.

FIGURE 15, POINT K TAPE \#2

FIGURE 16, POINT L TAPE \#1

FIGURE 17, POINT L TAPE \#2

FIGURES

FIGURE 18, POINT M TAPE \#2

D-19

D-20

D-21

D-22

D-23

D-24

D-25

D-26

D-27

D-28

D-29

D-30

D-31

D-32

D-33

D-34

D-35

FIGURE 19, POINT N TAPE \#2

FIGURE 20, POINT P TAPE \#3

FIGURE 21, POINT R TAPE \#3

D-39

FIGURE 22, POINT S TAPE \#3

D-40

FIGURE 23, POINT S TAPE \#4

D-41

FIGURE 24, POINT T TAPE \#4 


\subsection{SCOPE}

The purpose of this Appendix is to document the evaluations of the non-destructive examinations performed on Tanks 101 and 102. The information developed here is used as a basis for the conclusions presented in the "Integrity Assessment for Tanks 101 and 102" (Reference 1).

\section{INSPECTION METHODS}

The Department of Ecology's Publication No.94-114 "Guidance of Assessing and Certifying Tank Systems that Store and Treat Dangerous Waste" (Reference 2) recommends that existing tanks be evaluated by a leak test were feasible. Where a leak test is not feasible tanks may be assessed by a external inspection combined with an internal inspection and a non destructive examination such as a Ultrasonic Testing. The internal visual examination may be performed remotely (i.e. with a video camera) if necessary. Tanks 101 and 102 were inspected by an external examination, an internal visual examination and ultrasonic testing (UT).

\section{INSPECTION REPORTS}

Inspection reports for the nondestructive examinations are included in Attachments 1 through 3. These reports are final reports and represent inspections made throughout the examination and construction phases. Attachment 1 is the inspection report, which summarizes the inspection of the exterior of tanks. Attachment 2 summarizes the inspection of the interior of the tanks. Also included in Attachment 2 is the method used to determine the location of points inside the tank from the different camera positions. Attachment 3 summarizes the Ultrasonic Testing. The order that the inspection reports are presented in this Appendix is base on the organization of the data presented and is not chronological.

\subsection{VISUAL EXAMINATION}

The interior and exterior of the tanks were inspected, looking for areas that were discolored, cracked, or pitted. A Quality Control (QC) inspector performed a visual inspection of the tanks. QC inspector qualification information and the inspection procedure used are located in Appendix $A$ and $B$ of this document.

Exterior Inspection:

When the exterior of the tanks were visually inspected, the QC inspector noted that the tanks were in good condition with some discoloration on the bottom of the tanks. The discoloration could be removed using a power brush (Attachment 1). The fact that the discoloration could be removed is an indication of surface stain and not a condition, which would deteriorate the stainless steel tank shell. The inspection report in Attachment 1 also documents inspection of the modification of the original tank legs. Carbon steel pads (feet) which were welded to the end of the leg were removed. The inspection report documents that the tank shell was not damaged during the removal process.

Interior Inspection:

Inspection of the tank interior was done using a video camera, since the radiation dose and contamination levels inside the tank were too high for manned entry. The method use to video the inside of the tank is presented in Appendix $C$ of this document. The $Q C$ inspector reviewed the videotapes and the results of this review are contained in Attachment 2. As noted in the inspection 
report for the tank interior, the inspector saw what appeared to be "anomalies" in the tank shell. Further review and evaluation of these anomalies was made by FDNW QC and Engineering. If necessary and where possible this re-evaluation was performed by looking at the anomaly with the camera at the second location. The method use to determine the second camera point is included in Attachment 2. The QC Inspector identified 17 anomalies or possible defects. Due to the volume of data, Table 1 was developed to summarize the results of this review. In Table 1 each anomaly location was given a letter. The table also includes information taken from the inspection report (Attachment 2), the location of the second camera data point, and the results of the QC/Engineering re-evaluation. To the extent possible still pictures of each point identified in Table 1 were made. These pictures are included in Figures 1 through 24.

\section{Summary of the Re-evaluation of the Anomalies}

Of the 17 anomalies identified 10 were noted as minor corrosion, pitting, or potential weld problems. The Re-evaluation of these anomalies shows that none of these areas were defects in the tank shell. The inspector also found six areas with marks that are possibly cracks (seven are identified in Table 1 however point $C$ and $N$ are the same point). There are five areas in Tank 101 (points $C \& N, H, J, K$, $M$ ) and one area in Tank 102 (point R). When these points were viewed from a different camera angle, three of the marks in Tank 101 could be dismissed (point $\mathrm{J}, \mathrm{K}$, and $\mathrm{M}$ ). For the remaining points (points $\mathrm{C} \mathrm{\&} \mathrm{N,} \mathrm{H}$, and $\mathrm{R}$ ) the pictures from the camera did not conclusively show that the anomalies are or are not cracks. The marks might also be from a grinder during the original fabrication, a surface imperfection in the plate during the manufacturing process, or something stuck to the surface. The worst case condition would be if the anomalies were cracks. If the anomalies are cracks they do not appear to be deep enough to cause the tanks to leak. This conclusion is aiso supported by the fact that the high pressure cleaning of the tanks used a water jet at 8000 psi. The pictures show that the water jet went over the area of the suspect crack. If the crack was through the tank wall the tank would have leaked during cleaning and no leak was found during cleaning. The operating pressure of the tank is largest at the bottom. The required thickness required to withstand operating pressure at the bottom tank is 0.062 inches. This leads to the conclusion that the tanks, even with the cracks will not leak for many years. The orientation of the marks are vertical, if the mark was actually a crack the tank would leak long before the crack would be large enough for the tank to structurally fail and collapse.

\subsection{ULTRASONIC TESTING}

Ultrasonic testing (UT) was used to determine the thickness of the top, bottom, and sides of the tank shell. A qualified QC inspector following an approved procedure and using calibrated equipment performed UT testing. The QC inspector qualification information and the inspection procedure use are located in Appendix A and B of this document. Areas were selected at random for the UT. The inspection reports for the UT testing are in Attachment 3. More than 150 measurements were taken on each tank with the minimum measurement being 0.48 inches (nominal 0.5 inches). The tank wall in the area under the cooling jacket was not measured since destructive removal of the cooling jacket would have been necessary to take the measurements. The decision not to remove the cooling jacket was made for the following reasons: first, the measurements taken demonstrate that the tank shell still has its original thickness; and second, the cooling jacket acts as an additional containment if the tank shell was to ever leak. 


\subsection{REFERENCES}

1. HNF-4589, Rev. 0, June 1999, David S McShane, Fluor Daniel Northwest

"Integrity Assessment Report of Tanks TK-101 and TK-102"

2. Publication No. 94-114, Washington State Department of Ecology, June 1994

"Guidance for Assessing and Certifying Tank Systems that Store and Treat Dangerous Waste"

3. WAC 173-303-640, "Tank Systems", January 1998

"Dangerous Waste Regulations"

TABLE 1,

SUMMARY OF EVALUATION OF INSPECTION DATA BY QUALITY CONTROL AND ENGINEERING

\begin{tabular}{|c|c|c|c|c|c|c|}
\hline \multirow{3}{*}{$\begin{array}{l}\text { POINT } \\
\text { NUMBER }\end{array}$} & \multicolumn{2}{|c|}{ 1ST CAMERA LOC. } & \multirow{3}{*}{$\begin{array}{c}\text { ANOMALY } \\
\text { DESCRIPTION }\end{array}$} & \multicolumn{2}{|c|}{ 2nd CAMERA LOC. } & \multirow[t]{3}{*}{ COMMENT AND CONCLUSION } \\
\hline & TAPE & TAPE & & TAPE & TAPE & \\
\hline & NUMBER & INDEX & & NUMBER & INDEX * & \\
\hline A & Tane $\# 1$ & $\mathbf{1 4 \cdot 3 0}$ & Minor Corrosion & Tape\# 2 & $1 \cdot 14 \cdot 10$ & No Corrosion Material Stuck to Side Wt \\
\hline B & Tape \#1 & $20: 30$ & Minor Pitting & Tape \#2 & $1: 11: 42$ & No Pitting Material Stuck to Side Wall \\
\hline C & Tape \# 1 & $47: 00$ & Possible Crack & Tape \# 2 & $55: 42$ & $\begin{array}{l}\text { Same as Point Number N. Possible } \\
\text { Crack }\end{array}$ \\
\hline D & Tape \# 1 & $48: 20$ & Minor Corrosion & Tape \# 2 & NA & No Corrosion Material Stuck on Side wall \\
\hline $\mathrm{E}$ & Tape \#1 & 1:05:45 & Minor Pitting & Tape \# 2 & NA & No Pitting Material Stuck to Side Wall \\
\hline $\bar{F}$ & Tape \#1 & 1:09:20 & Root Concavity (Weld) & Tape \# 2 & NA & $\begin{array}{l}\text { No Root Concavity; Weld is fillet weld, } \\
\text { what appears to be concavity is multiple } \\
\text { pass on the fillet weld. }\end{array}$ \\
\hline G & Tape \#1 & $1: 22: 20$ & Minor Pitting & Tape \#2 & $4: 23$ & No Pitting Material Stuck to Side Wall \\
\hline$H$ & Tape \#1 & $1: 28: 00$ & Possible Crack & Tape \# 2 & 13:02 & Possible Crack \\
\hline $\mathbf{J}$ & Tape \# 1 & 1:34:00 & Possible Crack & Tape \# 2 & 23:56 & No Crack Visible \\
\hline $\mathbf{K}$ & Tape \#2 & $5: 20$ & Possible Crack & Tape \#1 & NA & $\begin{array}{l}\text { No Crack Marks on the Bottom from the } \\
\text { Cleaning Process }\end{array}$ \\
\hline $\mathbf{L}$ & Tape \#2 & $17: 15$ & Minor Corrosion & Tape \# 1 & $1: 29: 14$ & No Corrosion Material Stuck on Side wall \\
\hline $\bar{M}$ & Tape \#2 & 48:00 & Possible Crack & Tape \#1 & NA & No Crack \\
\hline $\mathbf{N}$ & Tape \#2 & $55: 42$ & Possible Crack & Tape \#1 & 47:06 & $\begin{array}{l}\text { Same as Point Number C. Possible } \\
\text { Crack }\end{array}$ \\
\hline$\overline{\mathbf{P}}$ & Tape \#3 & $26: 30$ & Minor Corrosion & Tape \# 4 & NA & No Corrosion Material Stuck on Side wall \\
\hline $\mathbf{R}$ & Tape \#3 & $1: 30: 56$ & Possible Crack & Tape \#4 & NA & Possible Crack \\
\hline $\mathbf{S}$ & Tape \# 4 & $32: 00$ & Corrosion & Tape \#3 & $29: 20$ & No Corrosion Material Stuck on Side wall \\
\hline$T$ & Tape \#4 & $1: 15: 50$ & Porosity in Weld & Tape \#3 & NA & $\begin{array}{l}\text { No Porosity in weld the mark appears to } \\
\text { be something stuck to the Weld }\end{array}$ \\
\hline
\end{tabular}




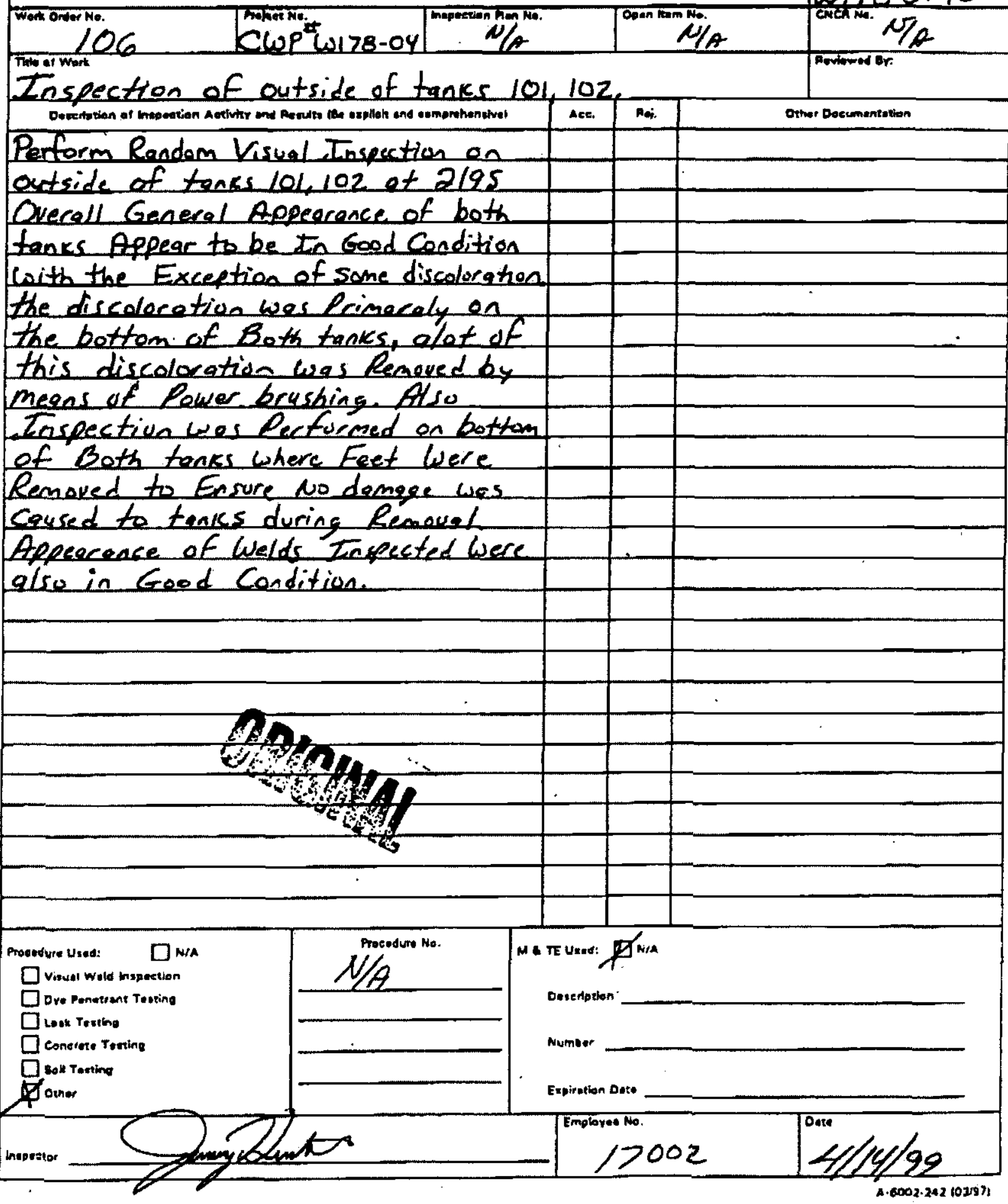




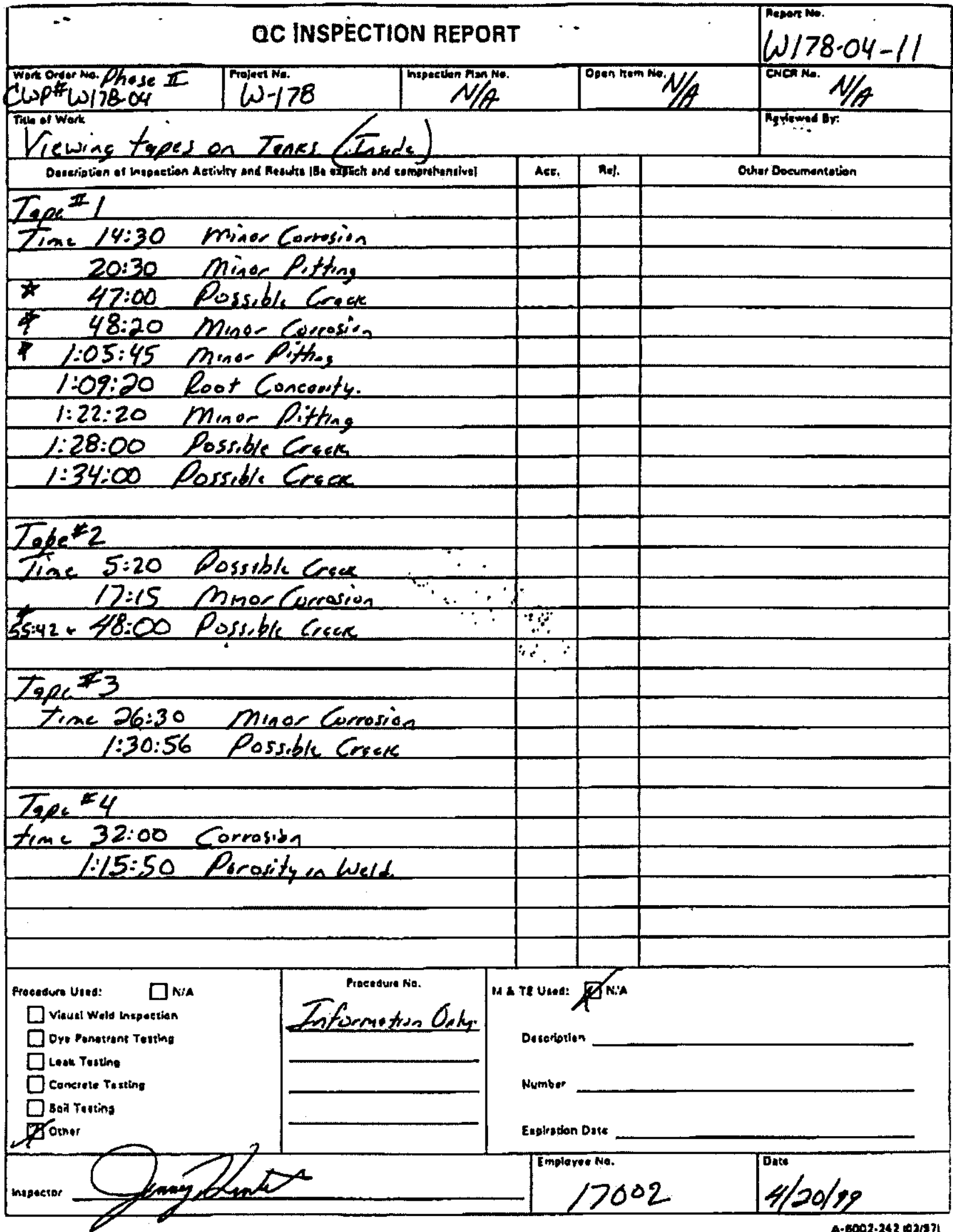



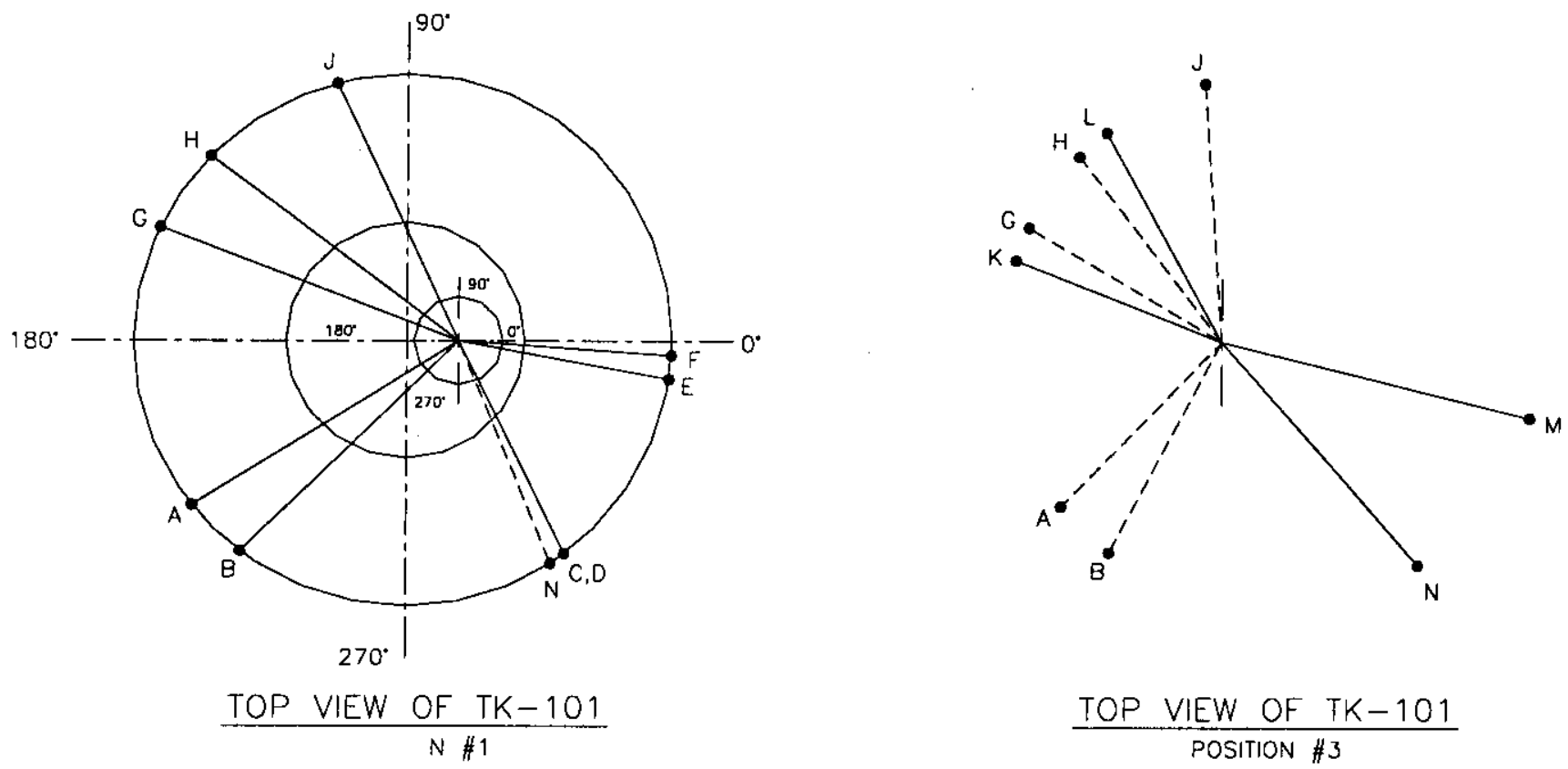

\begin{tabular}{|c|c|c|c|c|c|c|c|c|}
\hline \multicolumn{5}{|c|}{ TAPE \#1 - POSITION \#1 } & \multicolumn{4}{|c|}{ TAPE \#2 - POSITION \#3 } \\
\hline $\begin{array}{l}\text { TAPE } \\
\text { ID NO. }\end{array}$ & $\begin{array}{l}\text { TAPE } \\
\text { INDEX }\end{array}$ & $\begin{array}{c}\text { CAMERA } \\
\text { PAN ANGLE }\end{array}$ & $\begin{array}{l}\text { CAMERA } \\
\text { TILT ANGLE }\end{array}$ & $\begin{array}{c}\text { TANK } \\
\text { ANGLE } \\
\text { GRAPHICALLY } \\
\text { DETERMINED }\end{array}$ & $\begin{array}{l}\text { CAMERA PAN ANCLE } \\
\text { GRAPHICALLY } \\
\text { DETERMINED }\end{array}$ & $\begin{array}{l}\text { TAPE } \\
\text { INDEX }\end{array}$ & $\begin{array}{c}\text { CAMERA } \\
\text { PAN ANGLE }\end{array}$ & $\begin{array}{l}\text { CAMERA } \\
\text { TILT ANGLE }\end{array}$ \\
\hline $\begin{array}{l}A \\
B \\
C \\
D \\
E \\
F \\
G \\
H \\
J\end{array}$ & $\begin{array}{r}14: 30 \\
20: 30 \\
47: 08 \\
48: 20 \\
1: 05: 45 \\
1: 09: 20 \\
1: 22: 20 \\
1: 28: 00 \\
1: 34: 00 \\
\end{array}$ & $\begin{array}{l}212.40 \\
224.40 \\
296.64 \\
296.64 \\
349.56 \\
356.04 \\
158.76 \\
142.96 \\
115.20\end{array}$ & $\begin{array}{r}98.64 \\
96.12 \\
88.51 \\
126.00 \\
128.52 \\
\text { UNKNOWN } \\
\text { UNKNOWN } \\
\text { UNKNOWN } \\
\text { UNKNOWN }\end{array}$ & $\begin{array}{l}351.58 \\
163.76 \\
105.07\end{array}$ & $\begin{array}{r}46.49 \\
62.42 \\
134.61 \\
134.61 \\
172.95 \\
177.33 \\
339.32 \\
307.34 \\
273.88\end{array}$ & $\begin{array}{c}1: 14: 10 \\
1: 11: 42 \\
\text { NONE } \\
\text { NONE } \\
\text { NONE } \\
\text { NONE } \\
4: 23 \\
13: 02 \\
23: 56\end{array}$ & $\begin{array}{r}45.36 \\
59.04 \\
\text { NONE } \\
\text { NONE } \\
\text { NONE } \\
\text { NONE } \\
338.04 \\
312.84 \\
281.16\end{array}$ & $\begin{array}{r}97.56 \\
94.68 \\
\text { NONE } \\
\text { NONE } \\
\text { NONE } \\
\text { NONE } \\
95.04 \\
123.84 \\
139.68\end{array}$ \\
\hline
\end{tabular}

\begin{tabular}{|c|c|c|c|c|c|c|c|c|}
\hline \multicolumn{3}{|c|}{ TAPE \#2 - POSITION \#3 } & \multicolumn{4}{c|}{ TAPE \#1 - POSITION \#1 } \\
\hline $\begin{array}{l}\text { TAPE } \\
\text { ID NO. }\end{array}$ & $\begin{array}{c}\text { TAPE } \\
\text { INDEX }\end{array}$ & $\begin{array}{c}\text { CAMERA } \\
\text { PAN ANGLE }\end{array}$ & $\begin{array}{c}\text { CAMERA } \\
\text { TILT ANGLE }\end{array}$ & $\begin{array}{c}\text { TANK } \\
\text { ANGLE } \\
\text { GRAPHICALLY } \\
\text { DETERMINED }\end{array}$ & $\begin{array}{c}\text { CAMERA PAN ANGLE } \\
\text { GRAPHICALLY } \\
\text { DETERMINED }\end{array}$ & $\begin{array}{c}\text { TAPE } \\
\text { INDEX }\end{array}$ & $\begin{array}{c}\text { CAMERA } \\
\text { PAN ANGLE }\end{array}$ & $\begin{array}{c}\text { CAMERA } \\
\text { TILT ANGLE }\end{array}$ \\
\hline K & $5: 20$ & 338.04 & 149.76 & 161.79 & 165.08 & NONE & NONE & NONE \\
L & $17: 15$ & 298.80 & 96.48 & 128.61 & 136.33 & $7: 29: 14$ & 136.44 & UNKNOWN \\
M & $48: 00$ & NONE & NONE & 343.26 & 339.32 & NONE & NONE & NONE \\
N & $55: 42$ & 131.40 & 87.48 & 303.01 & 292.68 & $47: 06$ & 296.64 & 85.68 \\
\hline
\end{tabular}



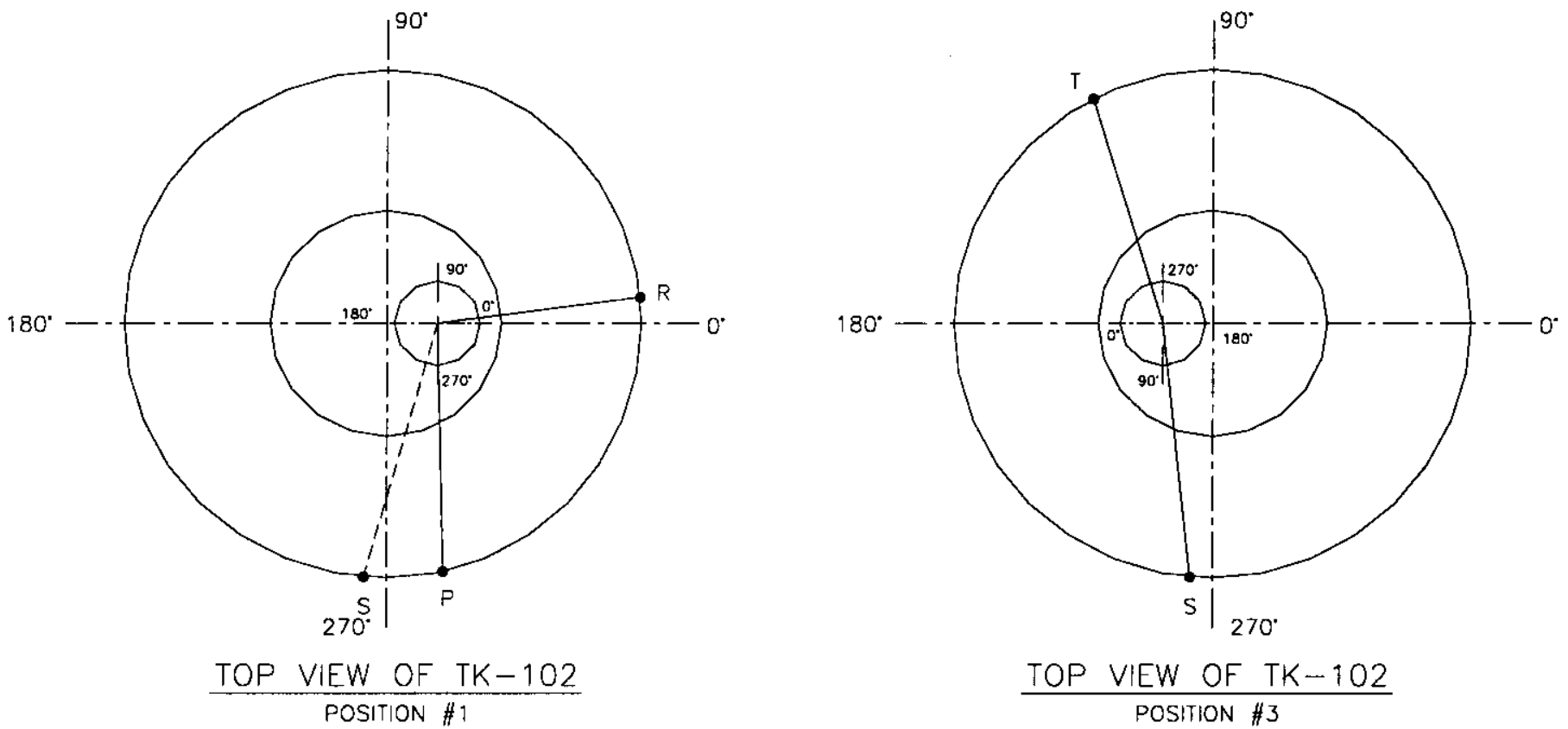

\begin{tabular}{|c|c|c|c|c|c|c|c|c|}
\hline \multicolumn{3}{|c|}{ TAPE \#3- POSITION \#1 } & \multicolumn{4}{|c|}{ TAPE \#4 - POSITION \#3 } \\
\hline $\begin{array}{c}\text { TAPE } \\
\text { ID NO. }\end{array}$ & $\begin{array}{c}\text { TAPE } \\
\text { INDEX }\end{array}$ & $\begin{array}{c}\text { CAMERA } \\
\text { PAN ANGLE }\end{array}$ & $\begin{array}{c}\text { CAMERA } \\
\text { TILT ANGLE }\end{array}$ & $\begin{array}{c}\text { TANK } \\
\text { ANGLE } \\
\text { GRAPHICALLY } \\
\text { DETERMINED }\end{array}$ & $\begin{array}{c}\text { CAMERA PAN ANGLE } \\
\text { GRAPHICALLY } \\
\text { DETERMINED }\end{array}$ & $\begin{array}{c}\text { TAPE } \\
\text { INDEX }\end{array}$ & $\begin{array}{c}\text { CAMERA } \\
\text { PAN ANGLE }\end{array}$ & $\begin{array}{c}\text { CAMERA } \\
\text { TILT ANGLE }\end{array}$ \\
\hline P & $26: 30$ & 271.44 & 128.52 & 282.65 & 112.96 & NONE & NONE & NONE \\
R & $1: 30: 56$ & 7.20 & 132.12 & 5.34 & 185.06 & NONE & NONE & NONE \\
\hline
\end{tabular}

\begin{tabular}{|c|c|c|c|c|c|c|c|c|}
\hline \multicolumn{3}{|c|}{ TAPE \#4 - POSITION \#3 } & \multicolumn{4}{c|}{ TAPE \#3 - POSITION \#1 } \\
\hline $\begin{array}{c}\text { TAPE } \\
\text { ID NO. }\end{array}$ & $\begin{array}{c}\text { TAPE } \\
\text { INDEX }\end{array}$ & $\begin{array}{c}\text { CAMERA } \\
\text { PAN ANGLE }\end{array}$ & $\begin{array}{c}\text { CAMERA } \\
\text { TILT ANGLE }\end{array}$ & $\begin{array}{c}\text { TANK } \\
\text { ANGLE } \\
\text { GRAPHICALIY } \\
\text { DETERMINED }\end{array}$ & $\begin{array}{c}\text { CAMERA PAN ANGLE } \\
\text { GRAPHICALLY } \\
\text { DETERMINED }\end{array}$ & $\begin{array}{c}\text { TAPE } \\
\text { INDEX }\end{array}$ & $\begin{array}{c}\text { CAMERA } \\
\text { PAN ANGLE }\end{array}$ & $\begin{array}{c}\text { CAMERA } \\
\text { TILT ANGLE }\end{array}$ \\
\hline$S$ & $32: 00$ & 96.12 & 149.04 & 264.97 & 254.90 & $29: 22$ & 258.12 & $\begin{array}{c}147.24 \\
\text { NONE }\end{array}$ \\
\hline
\end{tabular}




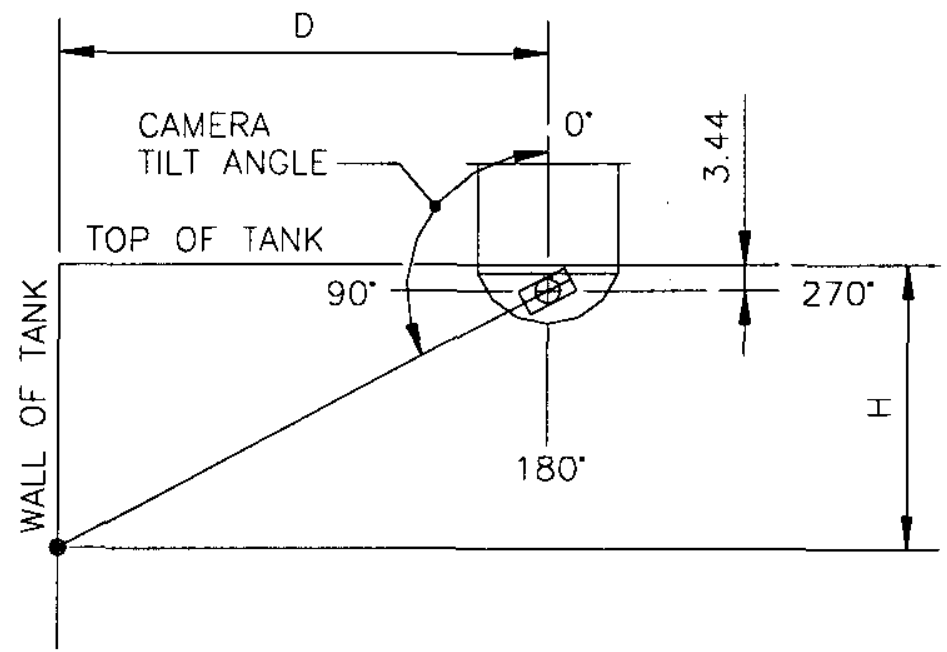

\begin{tabular}{|l|c|c|c|}
\hline \multicolumn{4}{|c|}{ CAMERA POSITION \#1 } \\
\hline $\begin{array}{l}\text { TAPE } \\
\text { ID NO. }\end{array}$ & $\begin{array}{c}\text { DISTANCE "D" } \\
\text { GRAPHICALLY } \\
\text { DETERMINED }\end{array}$ & $\begin{array}{c}\text { CAMERA } \\
\text { TILT ANGLE }\end{array}$ & $\begin{array}{c}\text { DISTANCE "H" } \\
\text { GRAPHICALLY } \\
\text { DETERMINED }\end{array}$ \\
\hline A, TAPE 1 & 62.57 & 98.64 & 12.95 \\
A, TAPE 2 & 46.23 & 97.56 & 9.57 \\
B, TAPE 1 & 60.97 & 96.12 & 9.97 \\
B, TAPE 2 & 48.33 & 94.68 & 7.39 \\
C. TAPE 1 & 48.47 & 88.51 & 0.00 \\
D. TAPE 1 & 48.47 & 126.00 & 38.65 \\
E, TAPE 1 & 43.64 & 128.52 & 38.18 \\
F, TAPE 1 & 43.52 & UNKNOWN & UNKNOWN \\
G, TAPE 1 & 63.65 & UNKNOWN & UNKNOWN \\
G, TAPE 2 & 44.73 & 95.04 & 7.38 \\
H, TAPE 1 & 62.01 & UNKNOWN & UNKNOWN \\
H, TAPE 2 & 46.98 & 123.84 & 34.94 \\
J, TAPE 1 & 57.63 & UNKNOWN & UNKNOWN \\
J, TAPE 2 & 52.26 & 139.68 & 65.02 \\
P. TAPE 3 & 52.71 & 128.52 & 45.40 \\
R, TAPE 3 & 43.57 & 132.12 & 42.83 \\
\hline
\end{tabular}

\begin{tabular}{|l|c|c|c|}
\hline \multicolumn{4}{|c|}{ CAMERA POSITION \#2 } \\
\hline $\begin{array}{l}\text { TAPE } \\
\text { ID NO. }\end{array}$ & $\begin{array}{c}\text { DISTANCE "D" } \\
\text { GRAPHICALLY } \\
\text { DETERMINED }\end{array}$ & $\begin{array}{c}\text { CAMERA } \\
\text { TILT ANGLE }\end{array}$ & $\begin{array}{c}\text { DISTANCE "H" } \\
\text { GRAPHICALLY } \\
\text { DETERMINED }\end{array}$ \\
\hline K, TAPE 2 & 44.12 & 149.76 & 79.12 \\
L, TAPE 2 & 48.15 & 96.48 & 8.91 \\
M, TAPE 2 & 64.13 & NONE & UNKOWN \\
N, TAPE 2 & 60.37 & 87.48 & 0.00 \\
N, TAPE 1 & 49.08 & 85.68 & 0.00 \\
S, TAPE 4 & 54.10 & 149.04 & 93.62 \\
S, TAPE 3 & 55.91 & 147.24 & 90.33 \\
T, TAPE 4 & 50.00 & 94.68 & 7.53 \\
\hline
\end{tabular}


ATTACHMENT 3

HNF-4621

Page 1 of 8 REV. 0

04/30/98 10:55 FAX

Q01

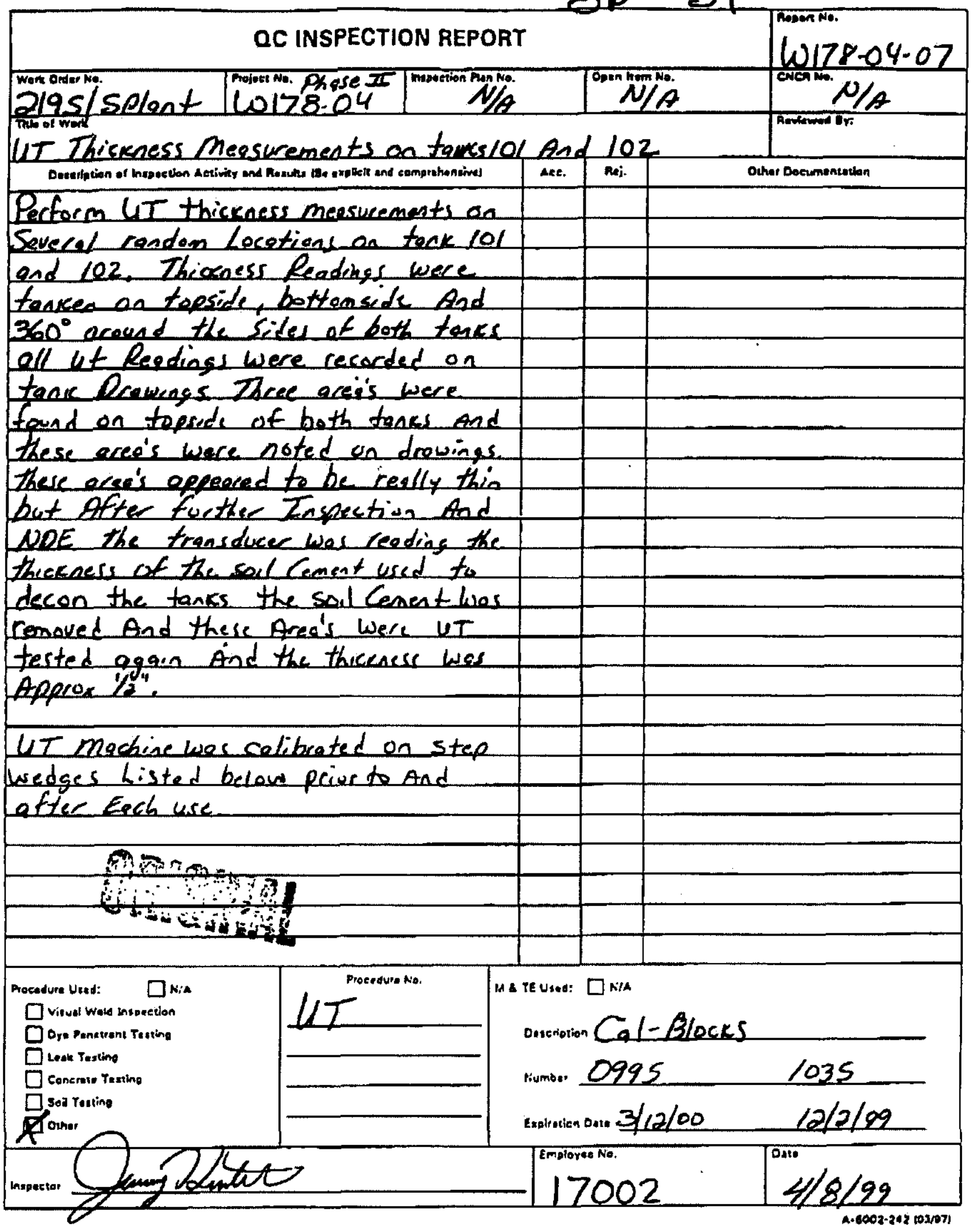

D-11 


\section{QC INSPECTION REPORT}

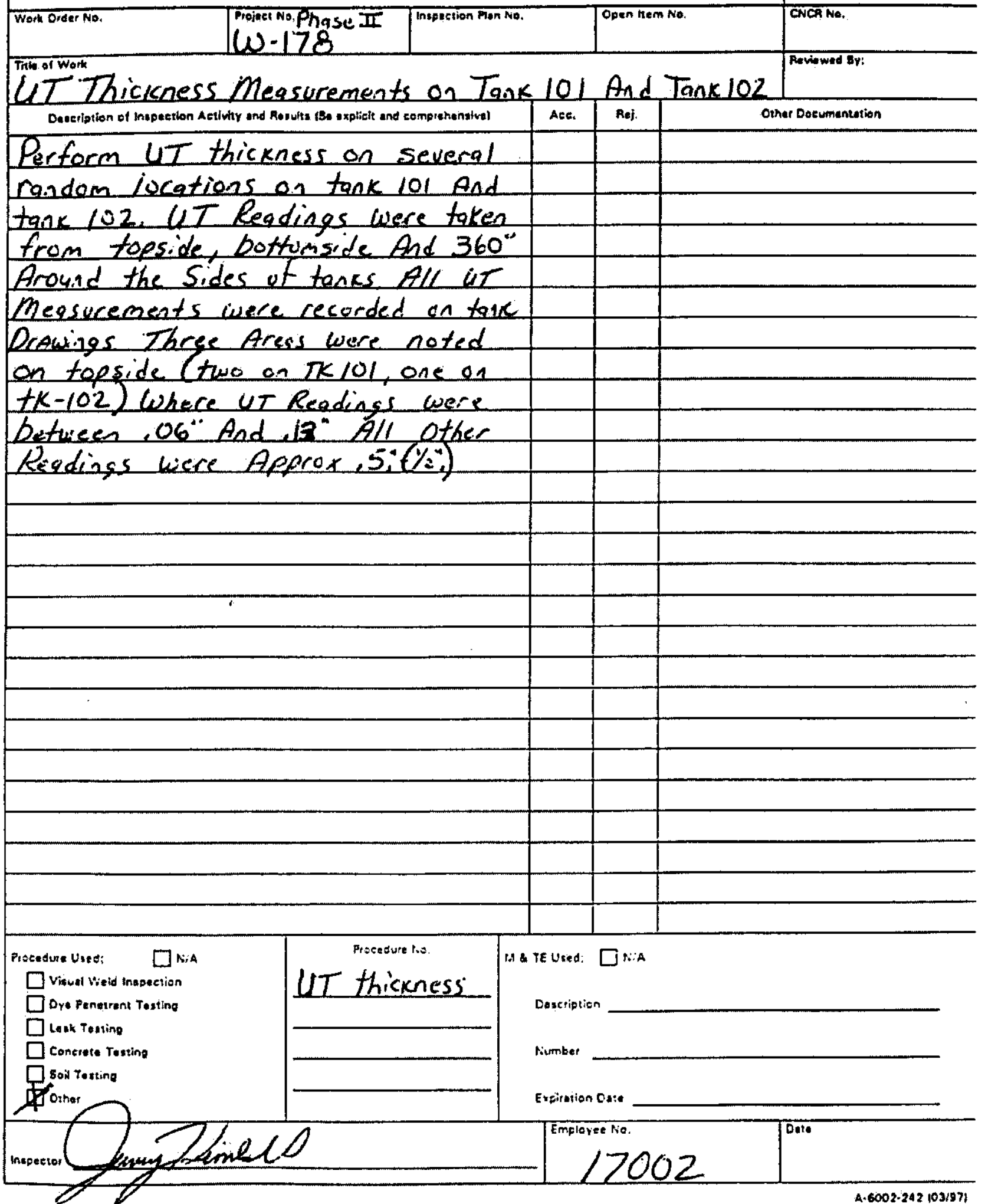



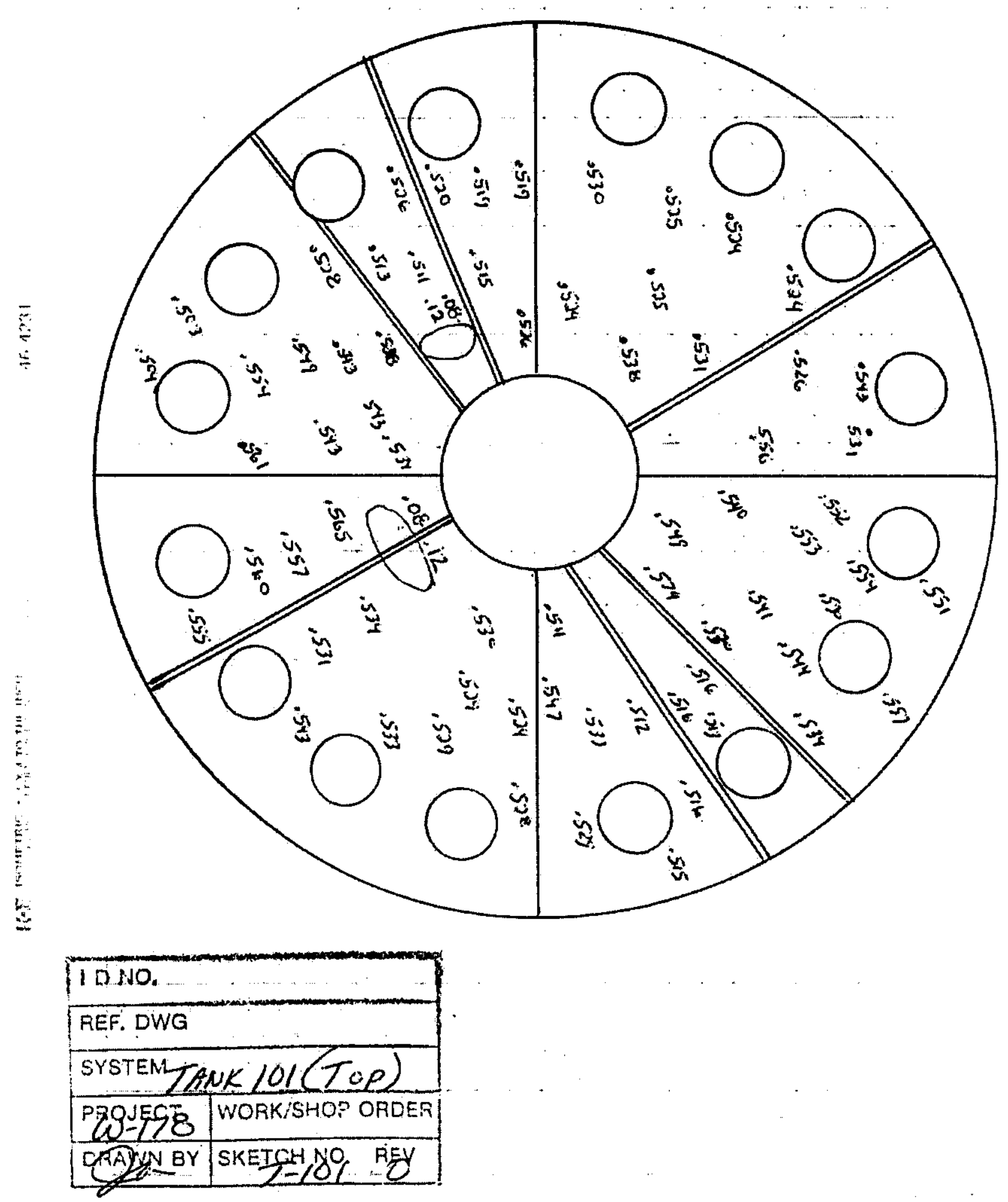


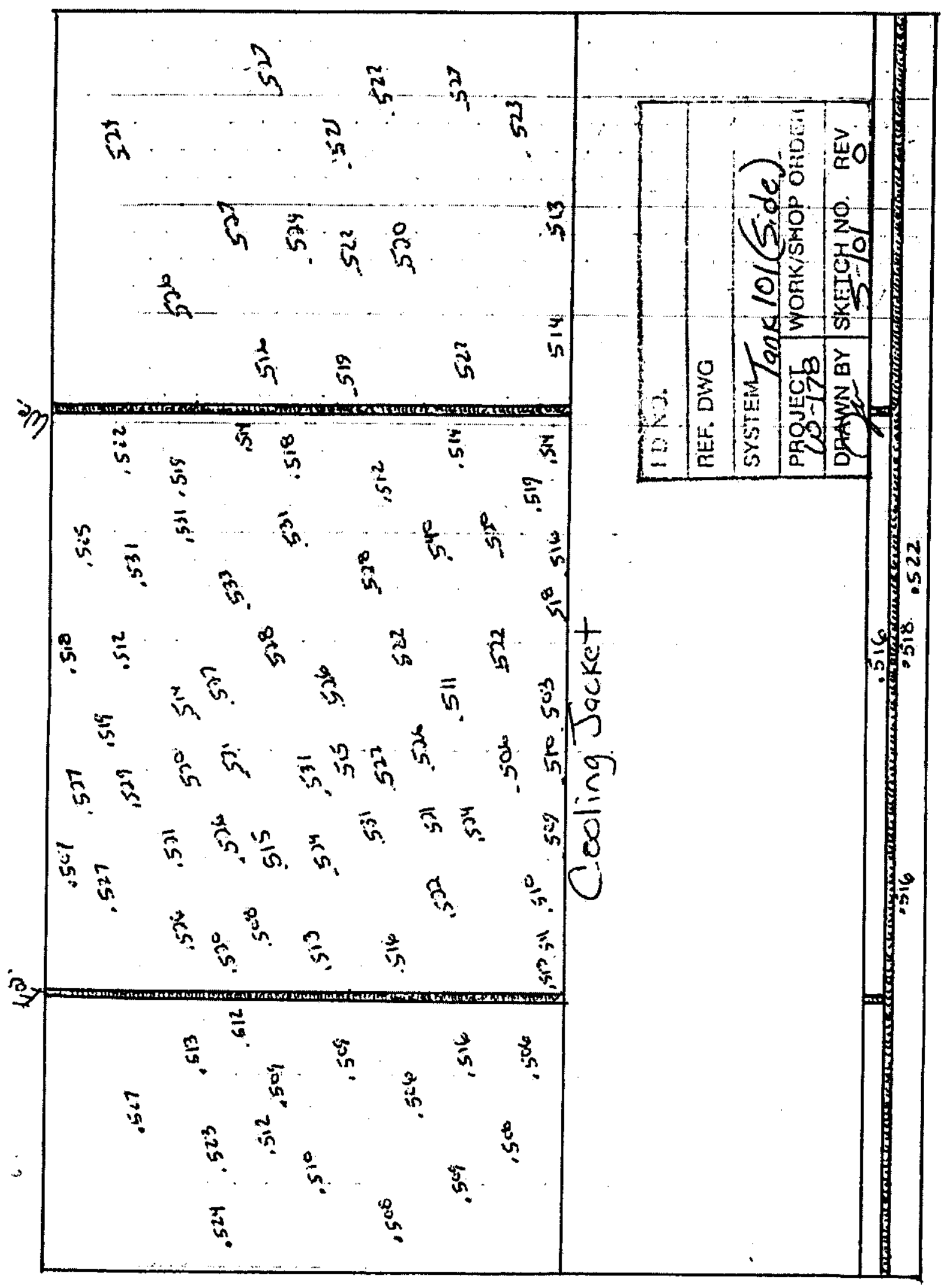




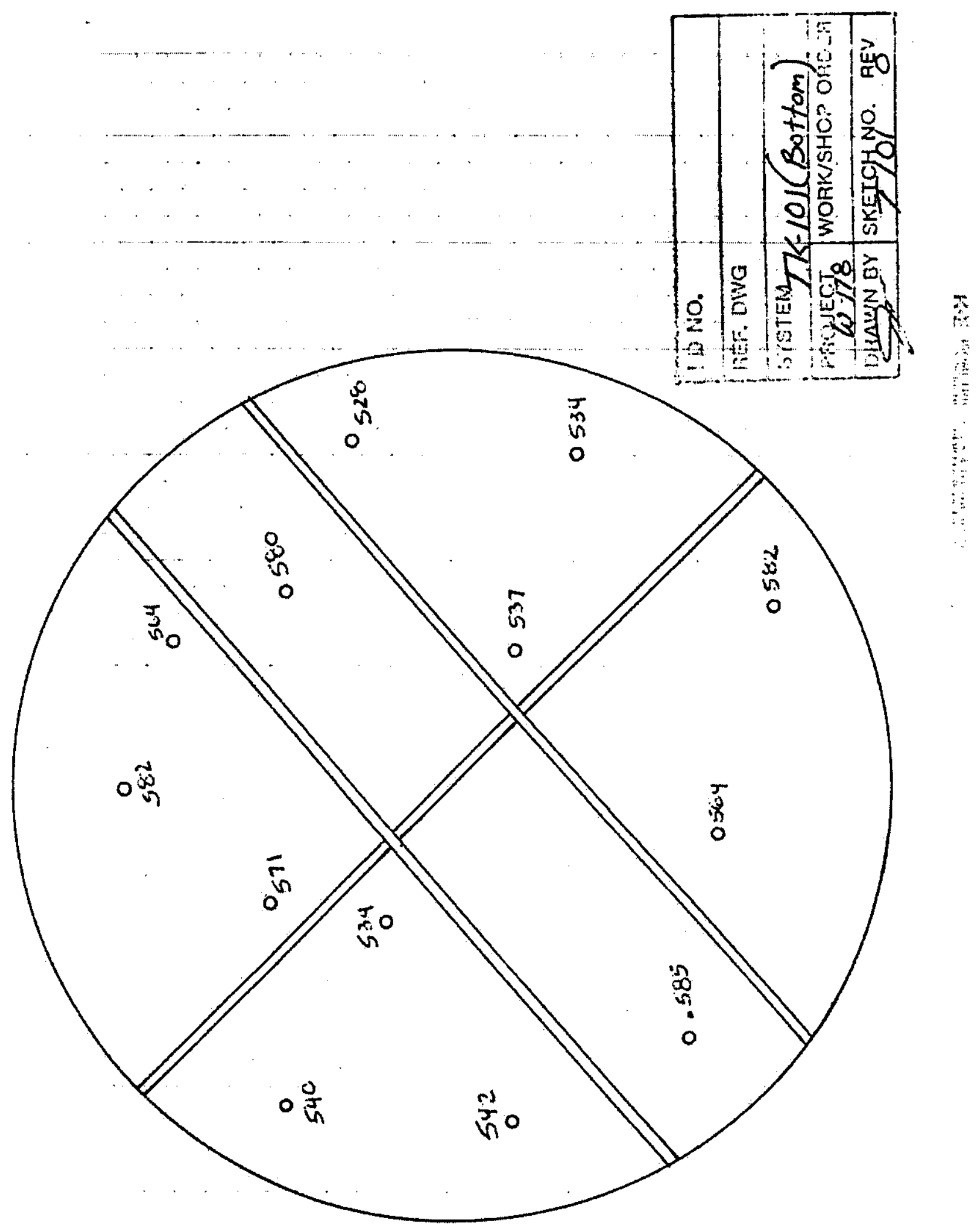




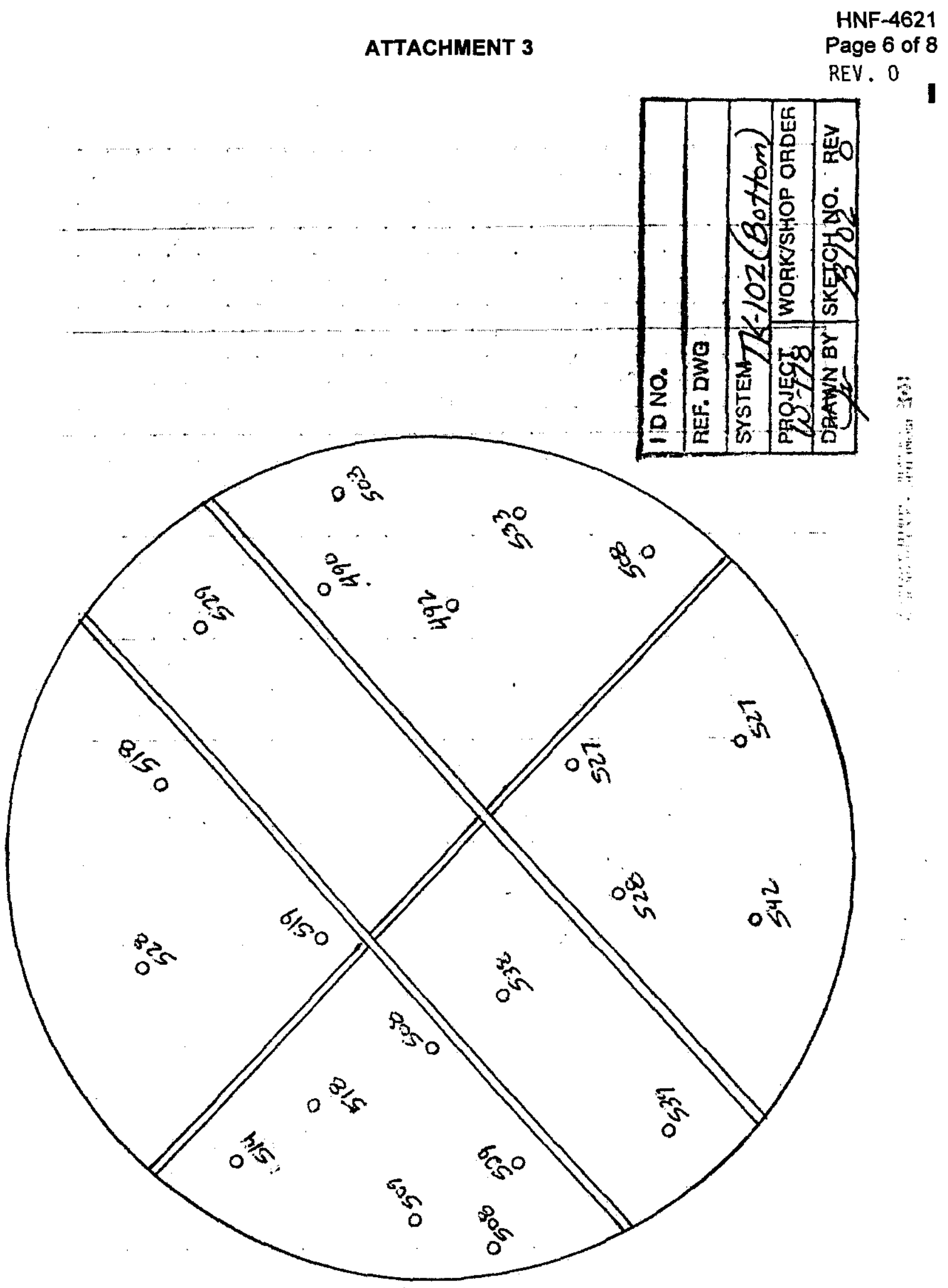

D-16 
ATTACHMENT 3

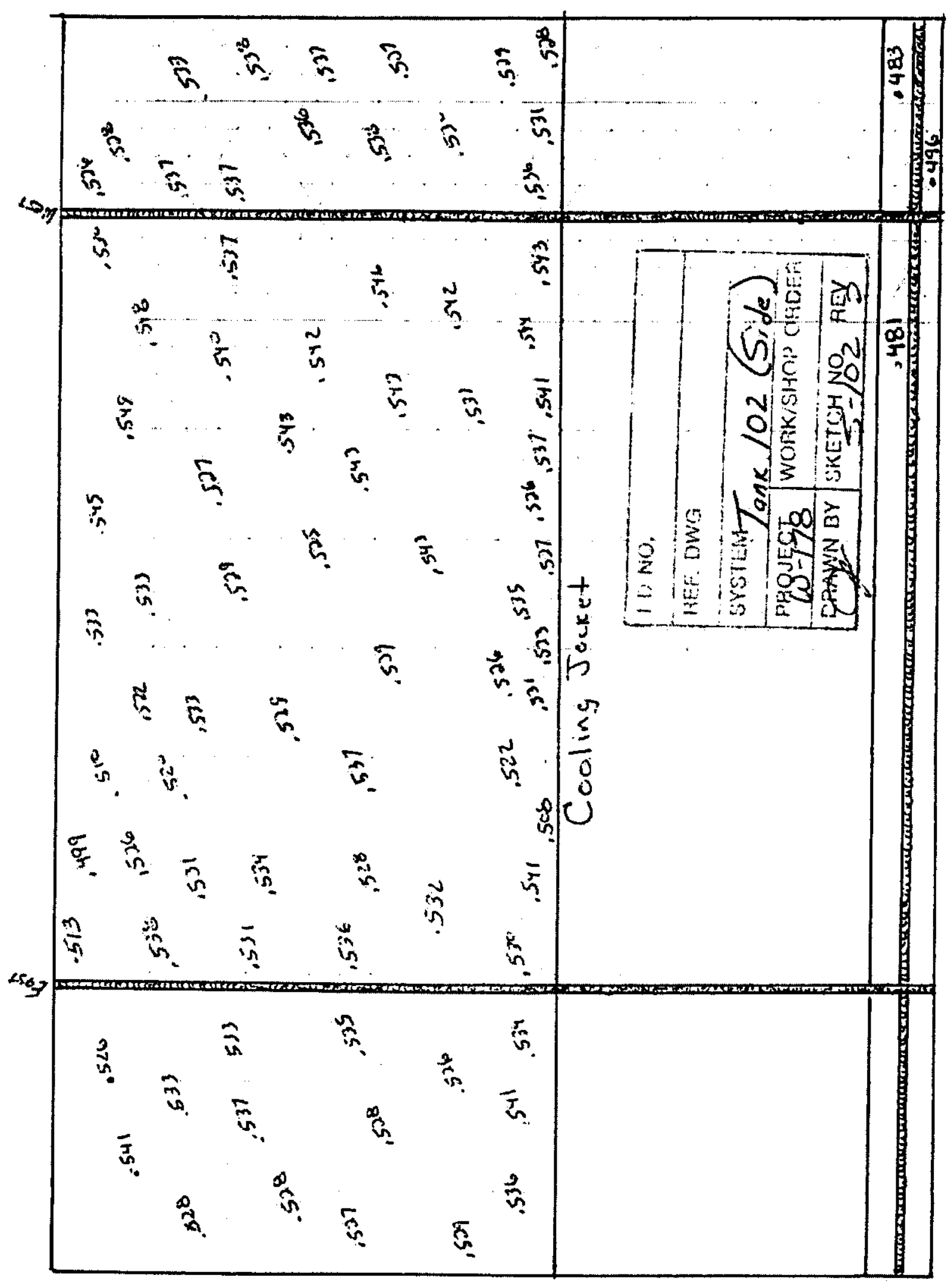

D-17

HNF-4621

Page 7 of 8

REV. 0 


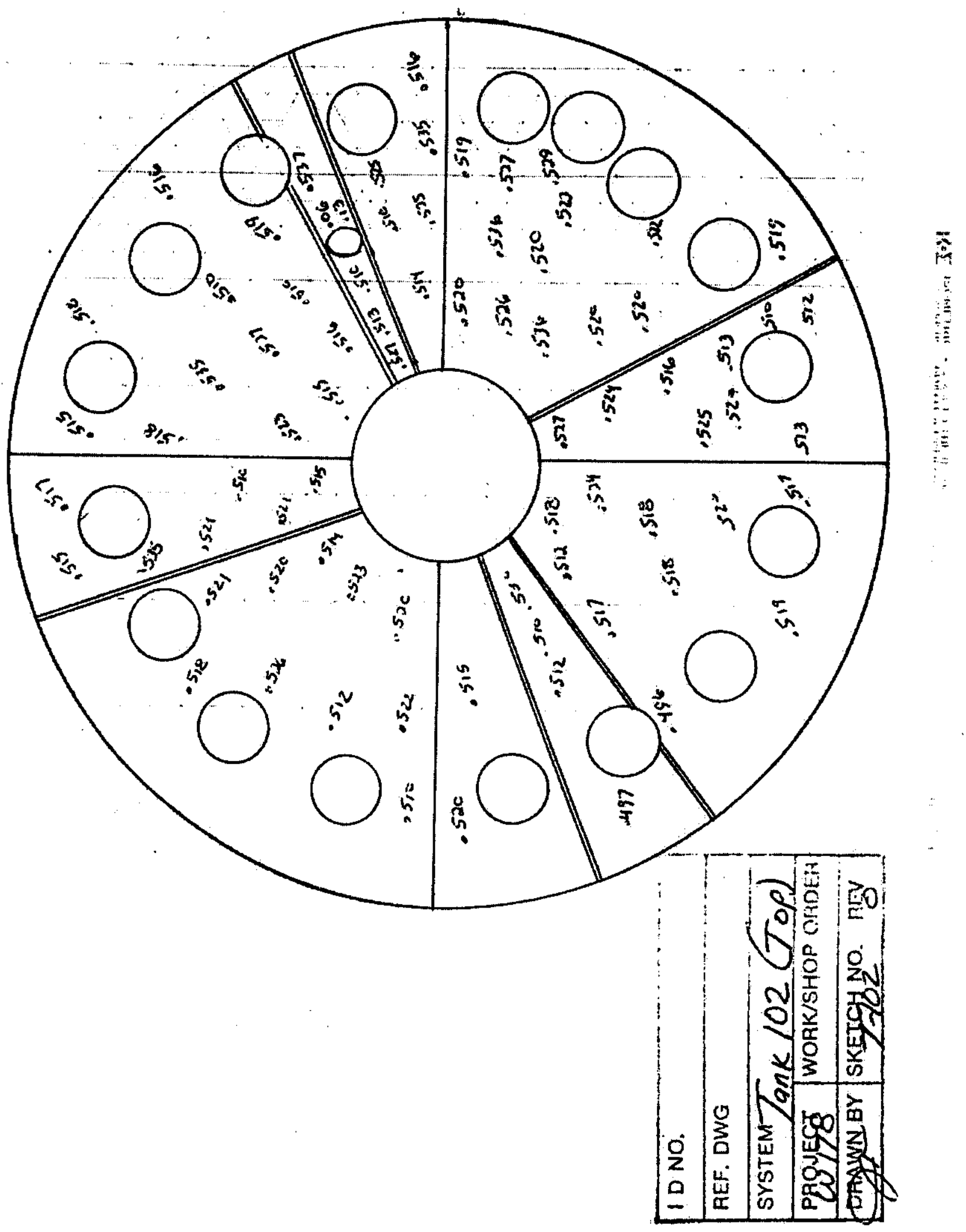




\section{FIGURE 1}

\section{POINT A TAPE \# 1}

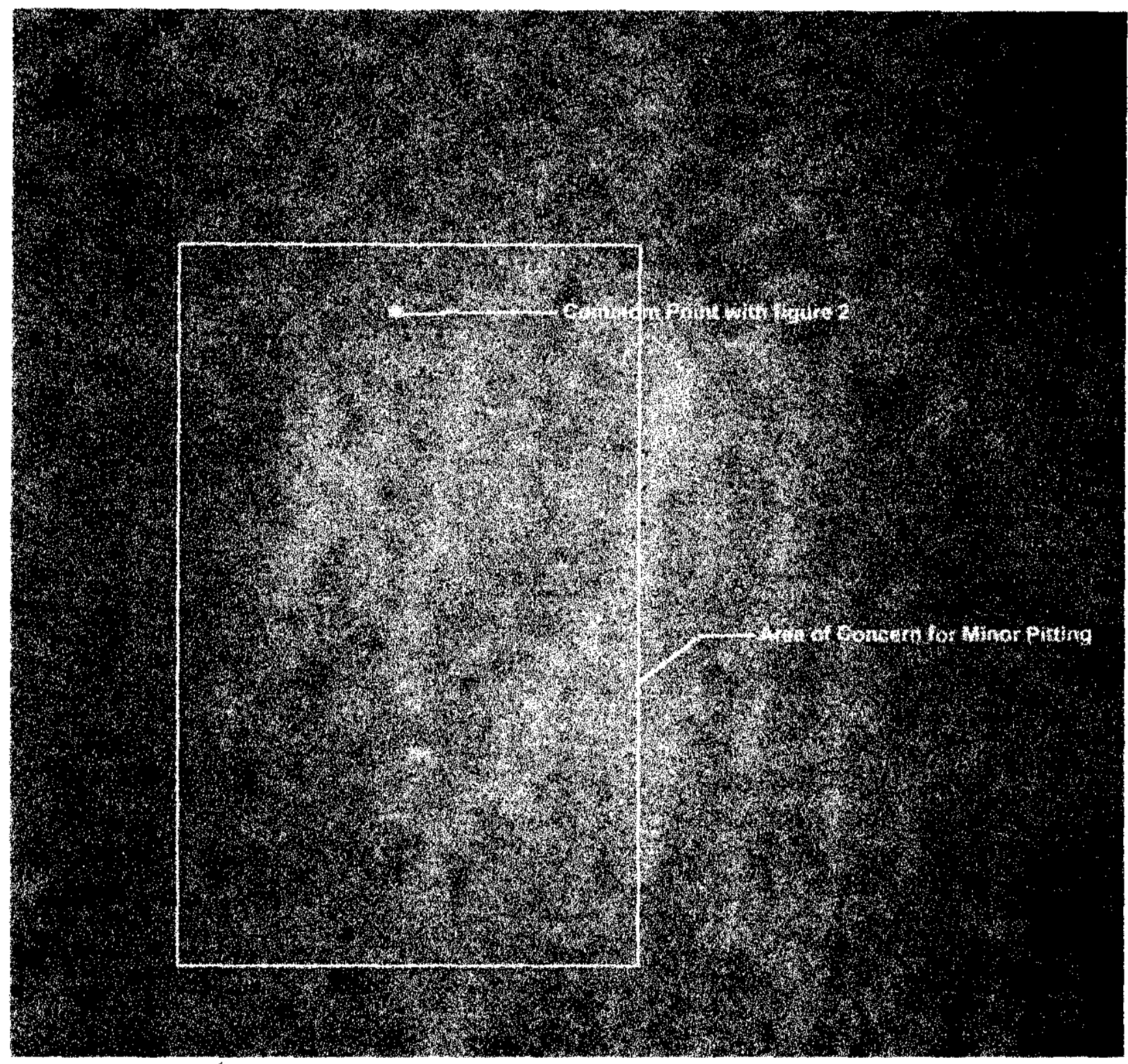

The dark spots could be possible corrosion. However further review of the video indicates that the dark spots are something stuck to the sidewall (shell) of the tank. 


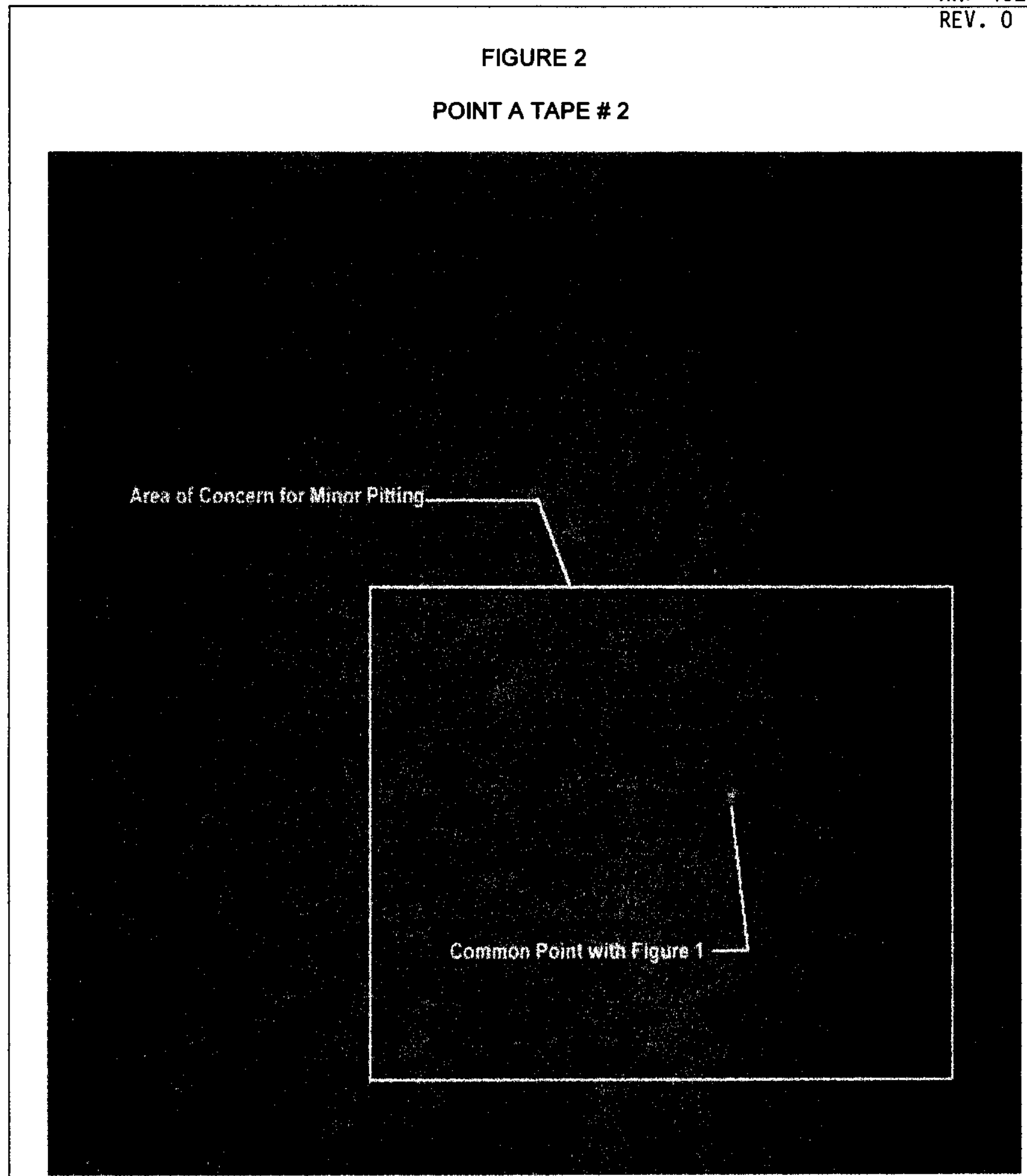

Comment: The dark spots are what is being viewed at possible Pitting. Upon further review the spots are something stuck to the side of the tank. 


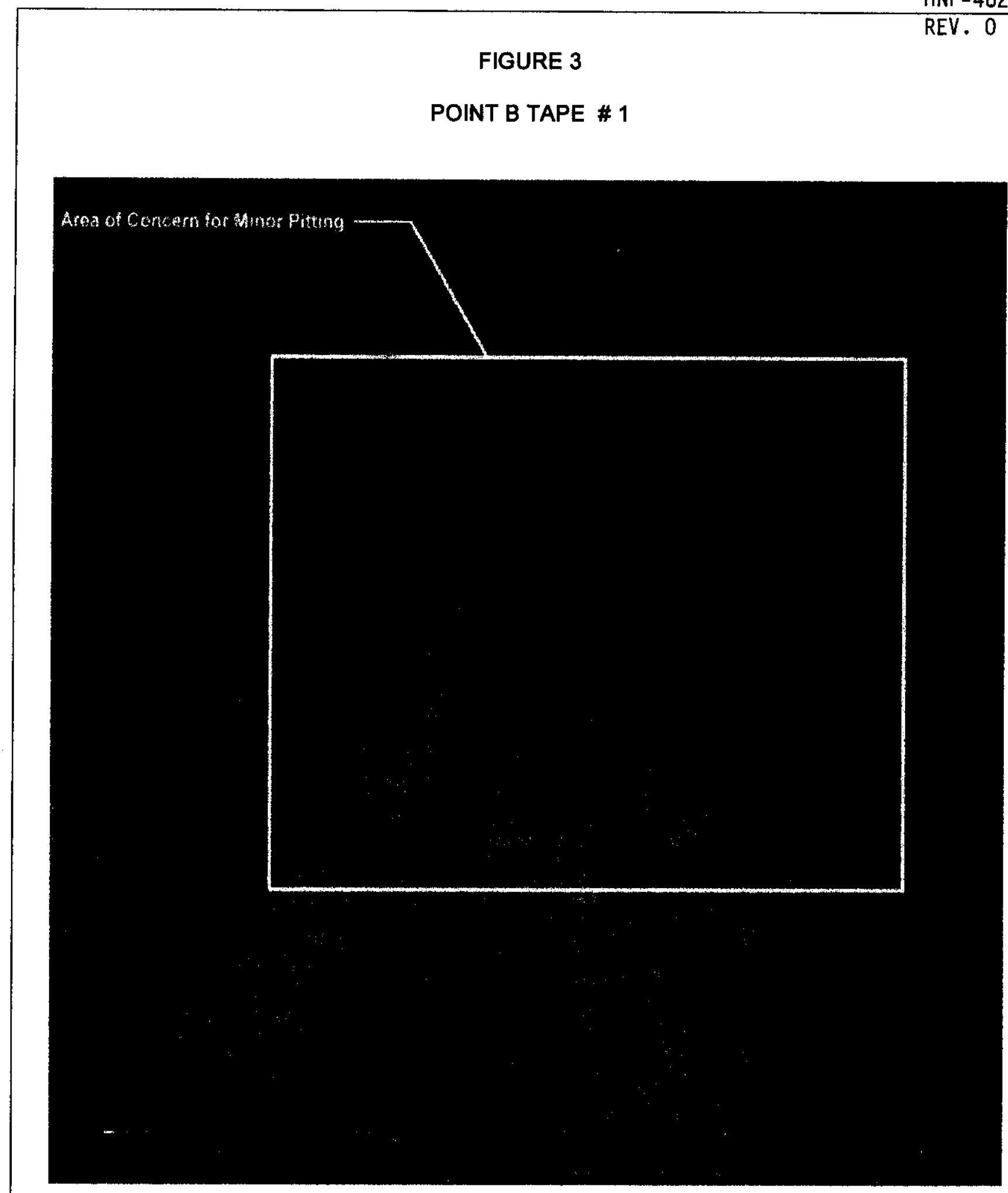

Comment: The dark spots are what is being viewed at possible Pitting. Upon further review the spots are something stuck to the side of the tank. 


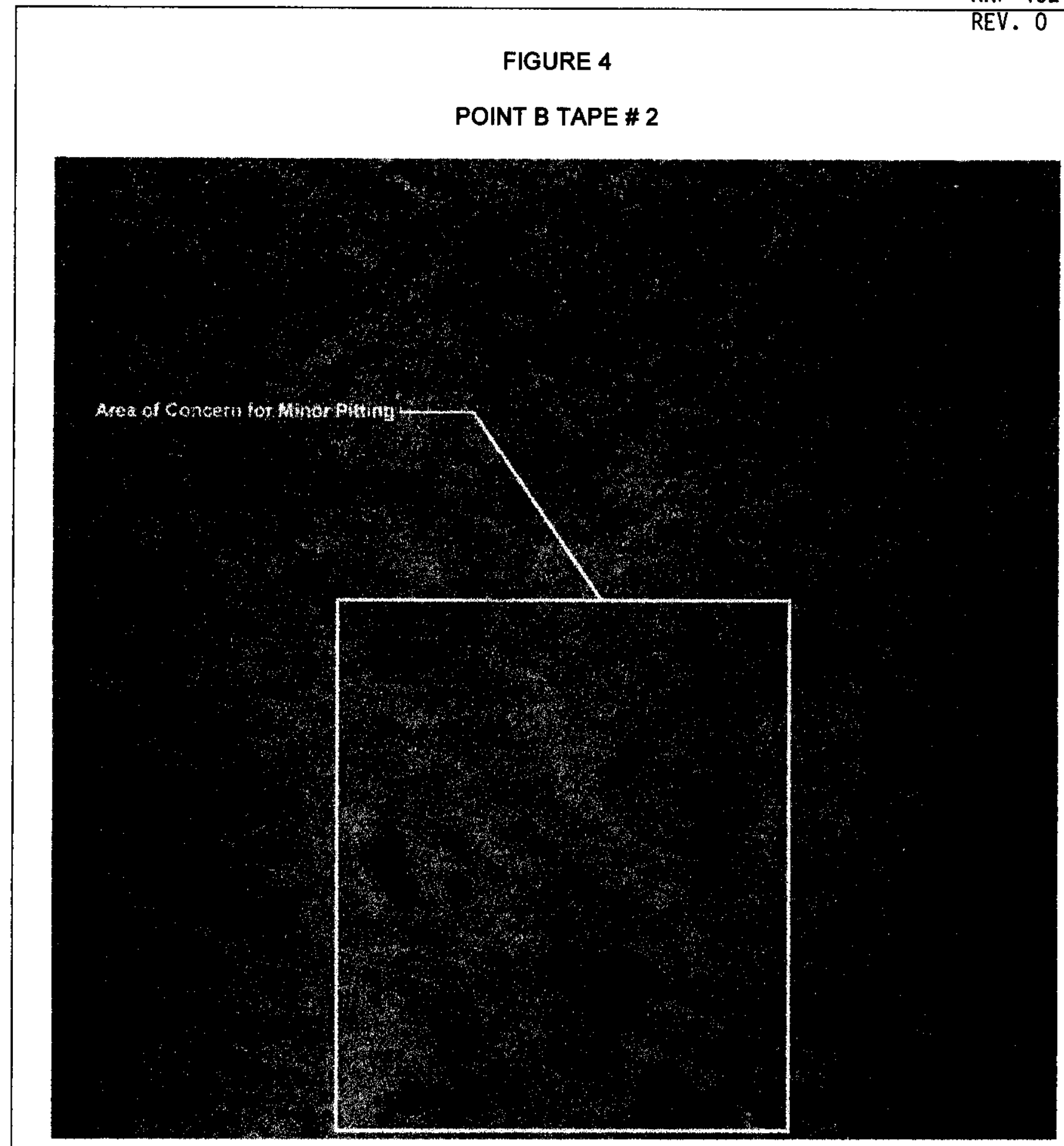

Comment: Upon further review the dark spots are something stuck to the side of the Tank. 


\section{FIGURE 5}

\section{POINT C TAPE \# 1}

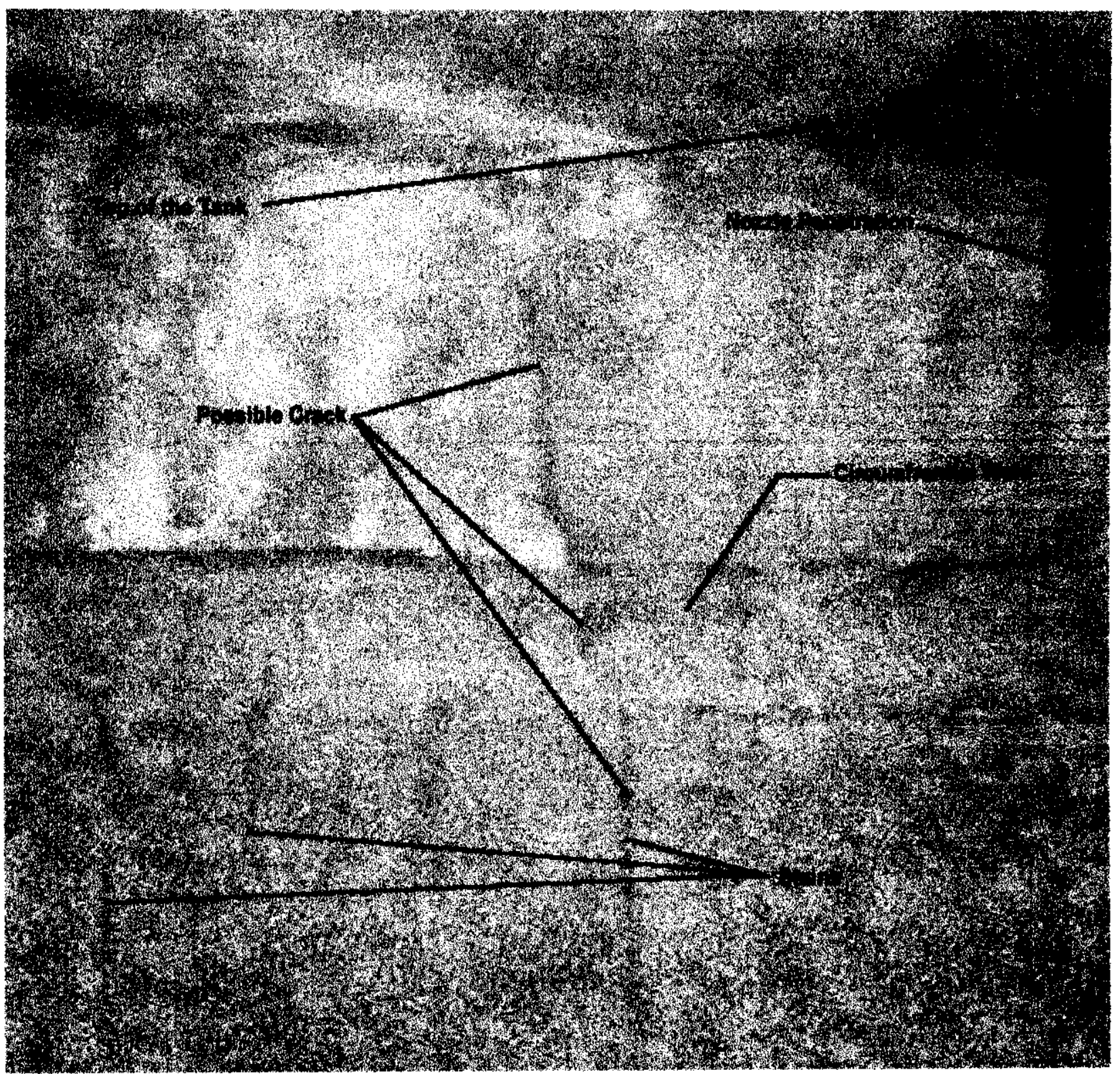

Comments: The area noted as a possible crack is a stain. Upon further review of the video the stain continues down 18 to 24 inches. 


\section{FIGURE 6}

\section{POINT D TAPE \# 1}

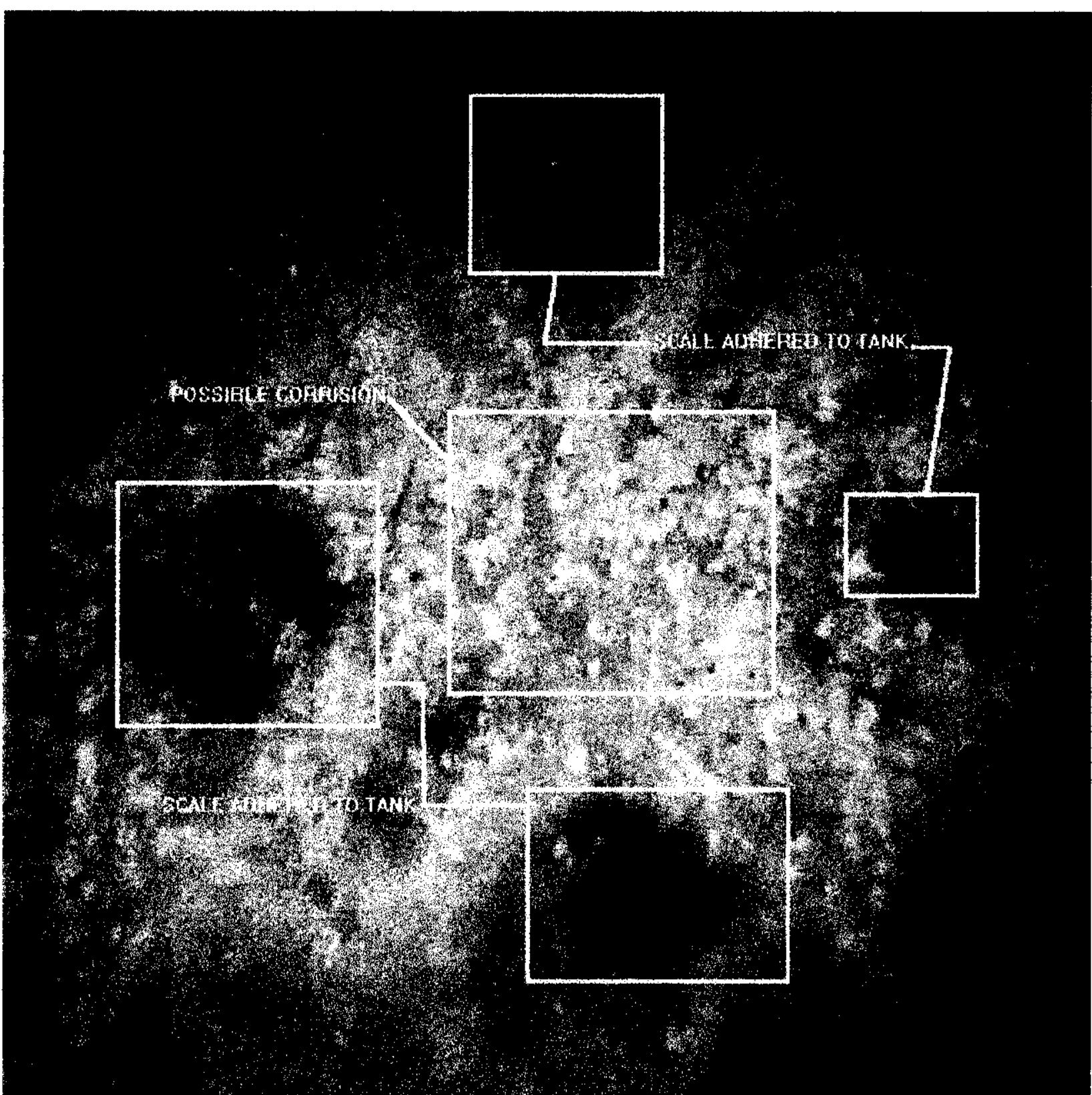

The area that appears to be corroded, the possible corrosion is in reality something, which is adhered to the tank. The brightest spots in the picture are the cleaned surface of the stainless steel tank shell. 


\section{FIGURE 7}

\section{POINT E TAPE \# 1}

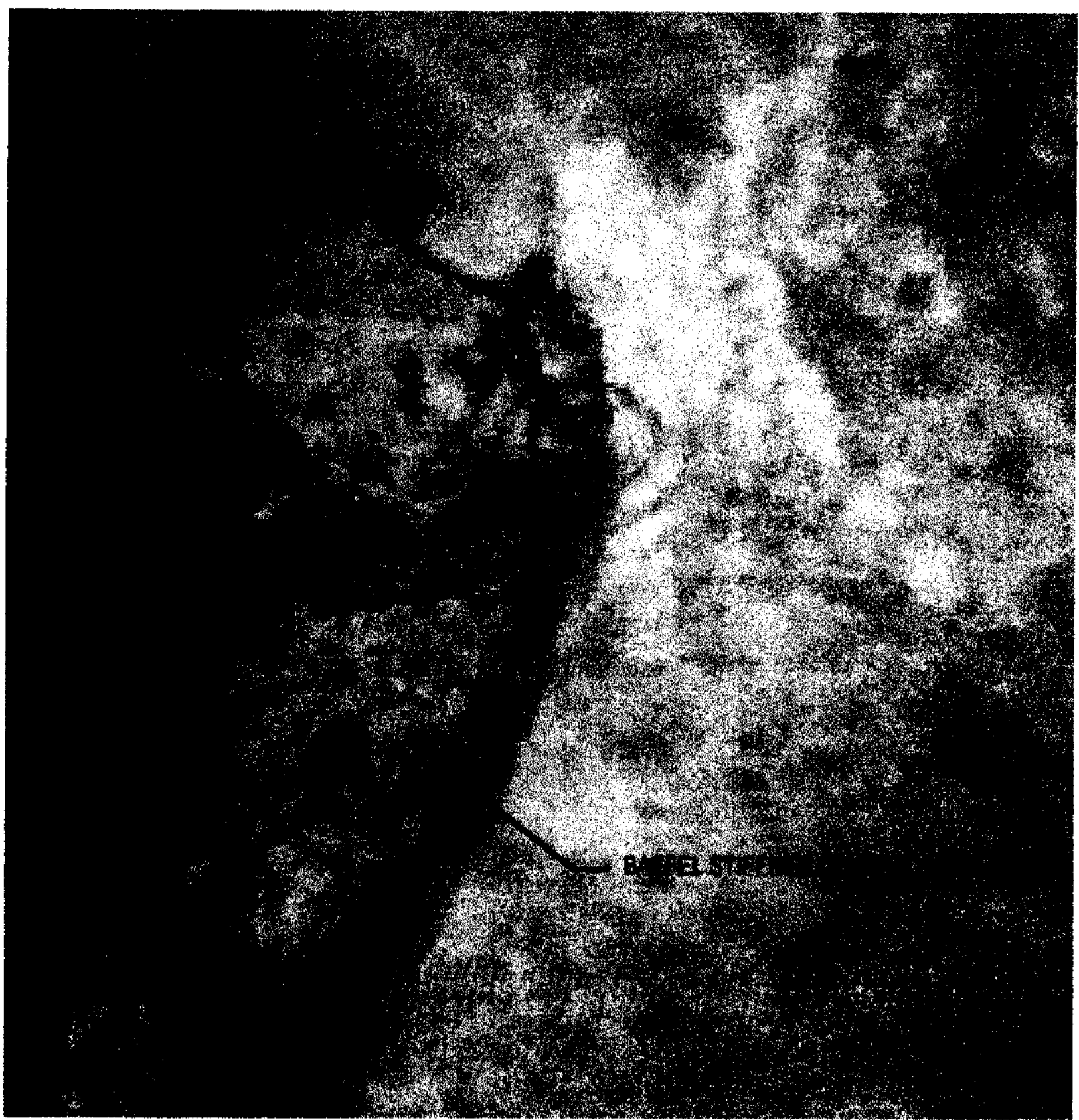

Comment: Upon further review of the area no pitting is noticed. 


\section{FIGURE 8}

\section{POINT F TAPE \# 1}

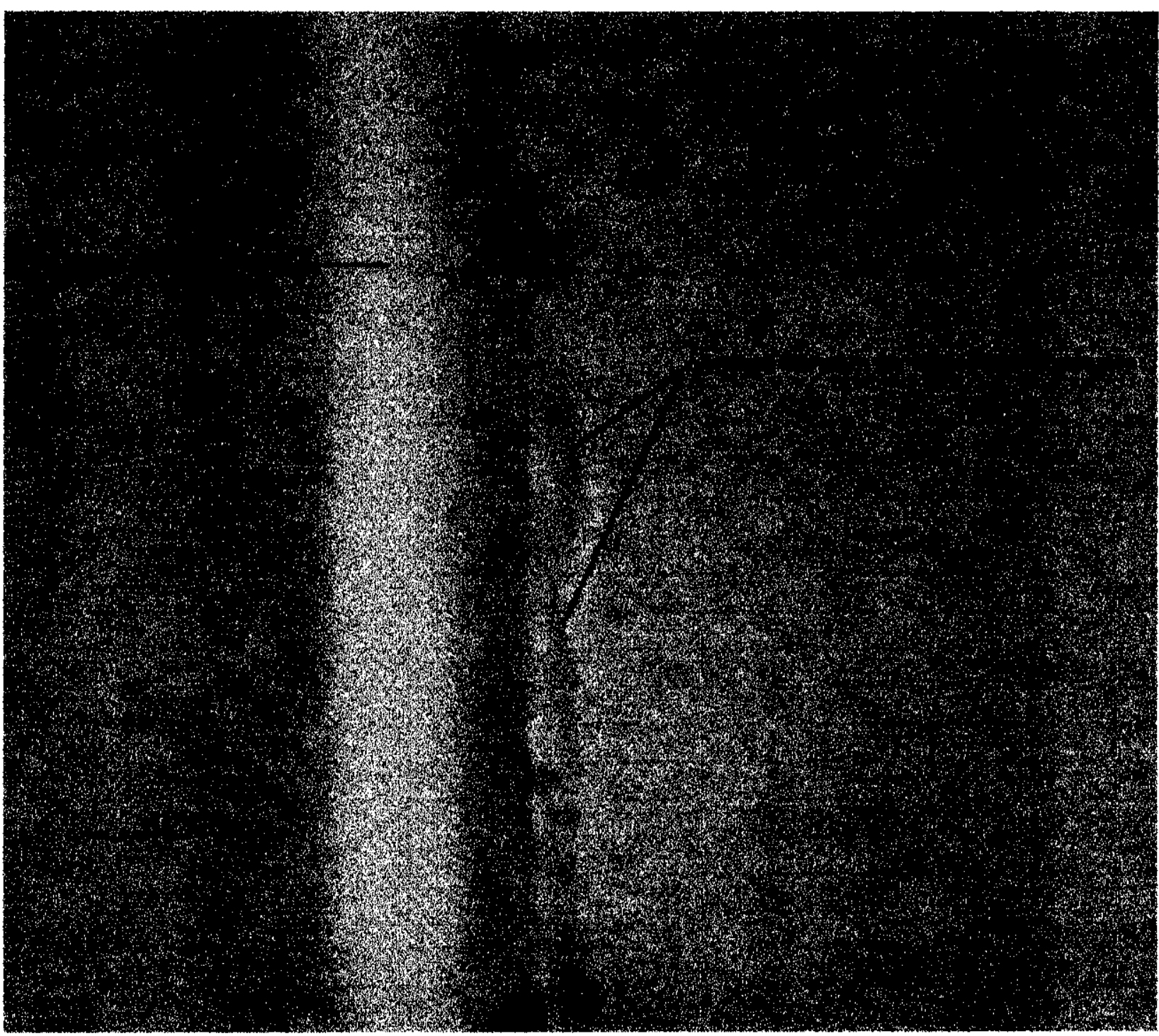

Comments: The weld shown above is a fillet weld. The area that is possible weld root concavity is not. The area shown is surface of the tank shell and the weld comes out not in. 


\section{FIGURE 9}

\section{POINT G TAPE \# 1}

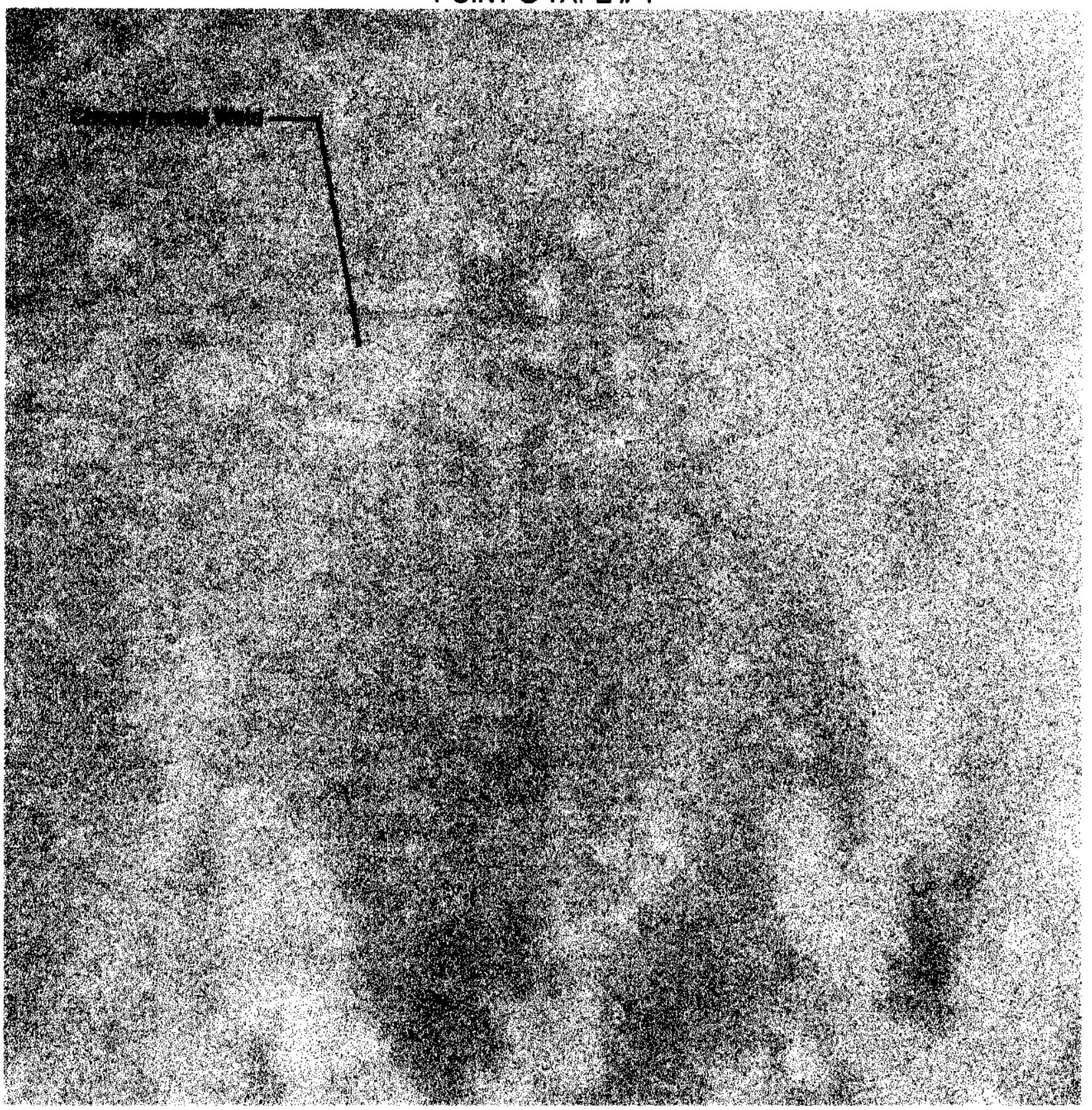

\section{Comment: Upon further review no pitting is visible.}




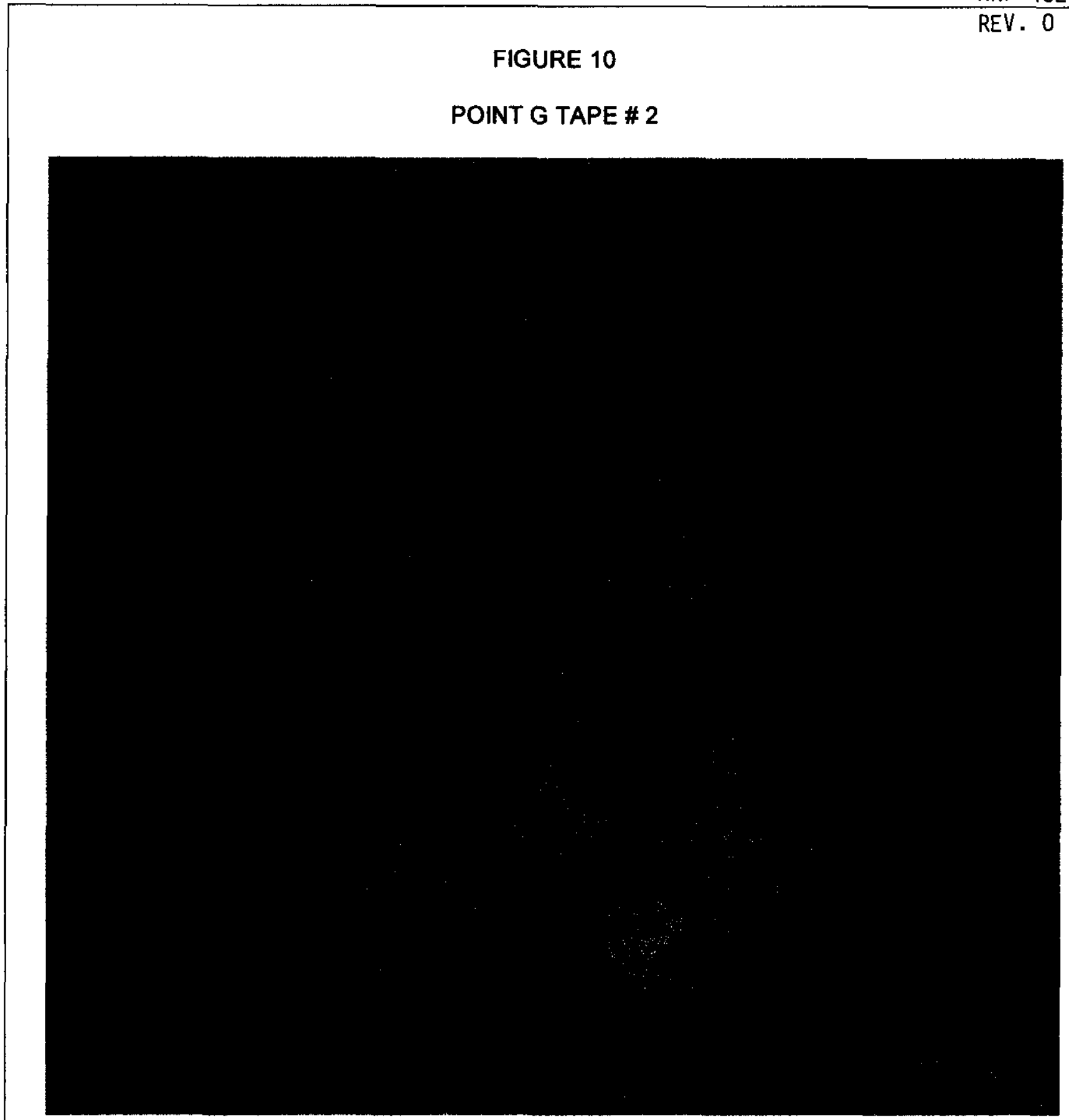

Comment: Upon further review no pitting is visible. The light areas are the stainless steel where the high-pressure water has shined the metal. The darker areas are where the highpressure water did not remove the scale. 
FIGURE 11

\section{POINT H TAPE \# 1}

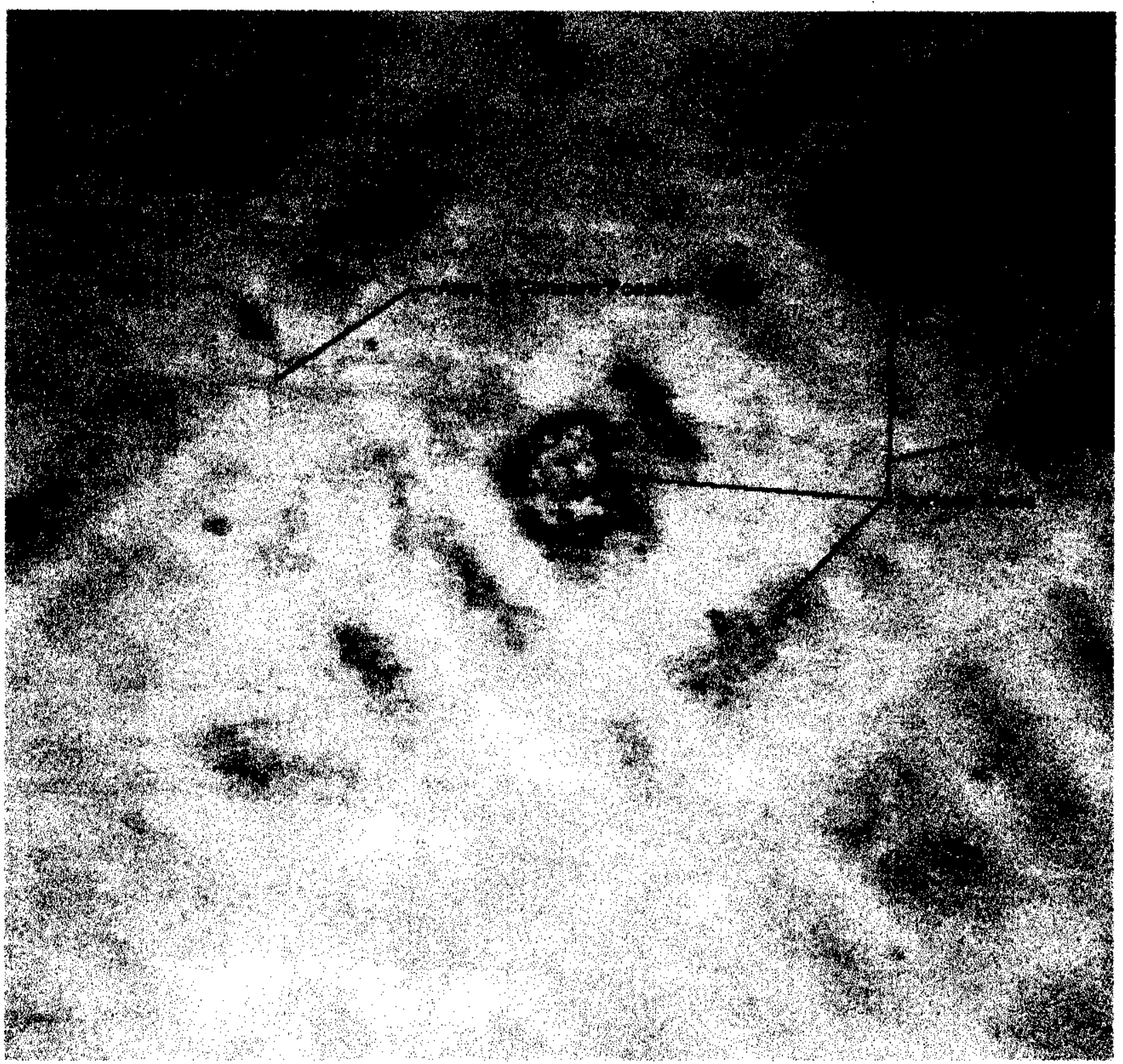

\section{Comment:}

The possible crack is more likely a surface imperfection filled with dirt. However, the possibility of a crack does exist. If this is a crack it is minor and just at the surface. The crack is vertical, which means if the crack does enlarge the tank will leak long before the tank fail, structurally. 


\section{FIGURE 12}

\section{POINT H TAPE \# 2}

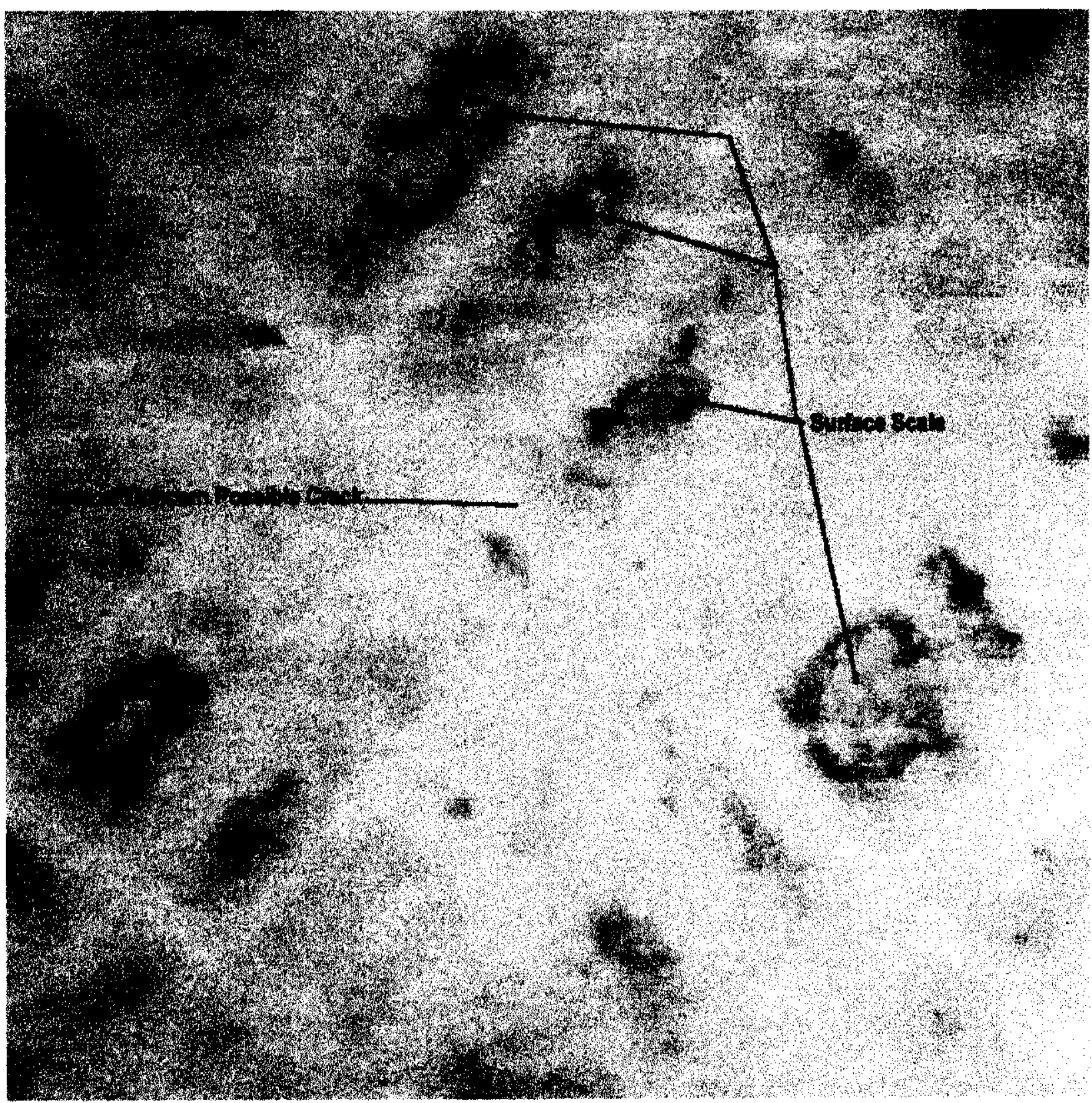

Comment: The possible crack is more likely a surface imperfection filled with dirt. However, the possibility of a crack does exist. If this is a crack it is minor and just at the surface. The crack is vertical, which means if the crack does enlarge the tank will leak long before the tank fails structurally. 


\section{FIGURE 13}

POINT J TAPE \# 1

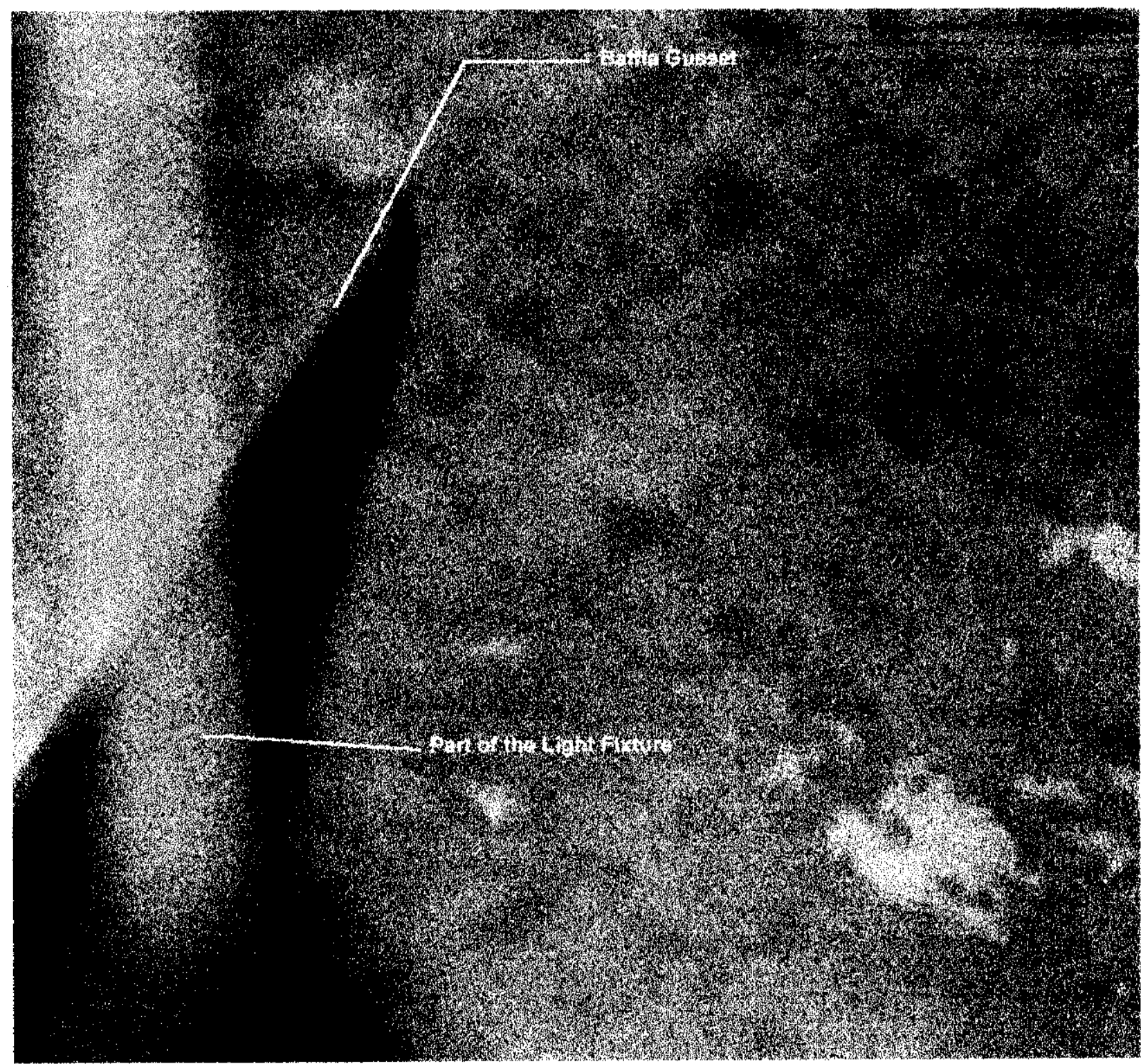

Comment: Upon further review no crack is apparent. 


\section{FIGURE 14}

\section{POINT J TAPE \# 2}

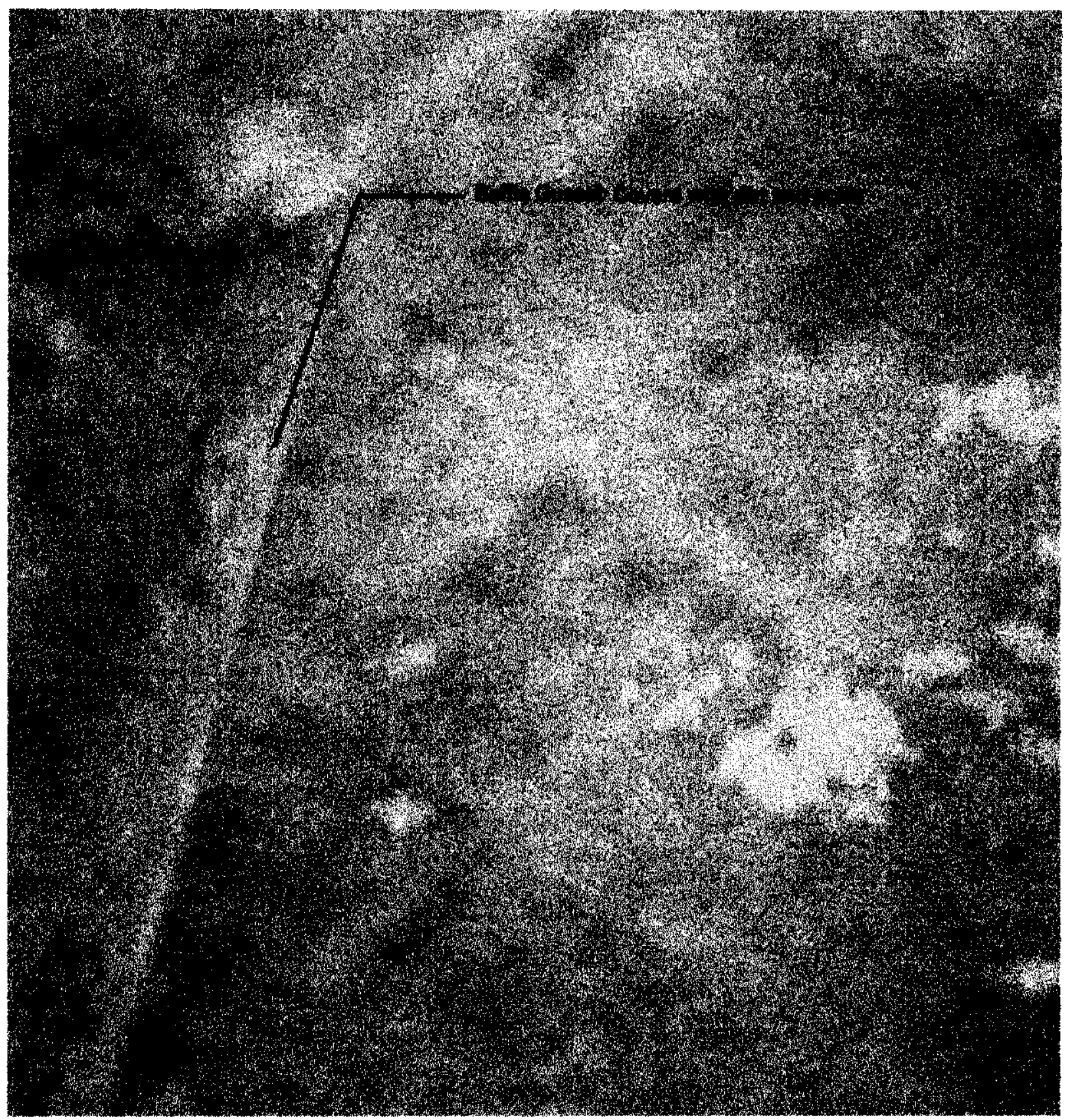

Comment: Upon further review no crack is visible. 


\section{FIGURE 15}

\section{POINT K TAPE \# 2}

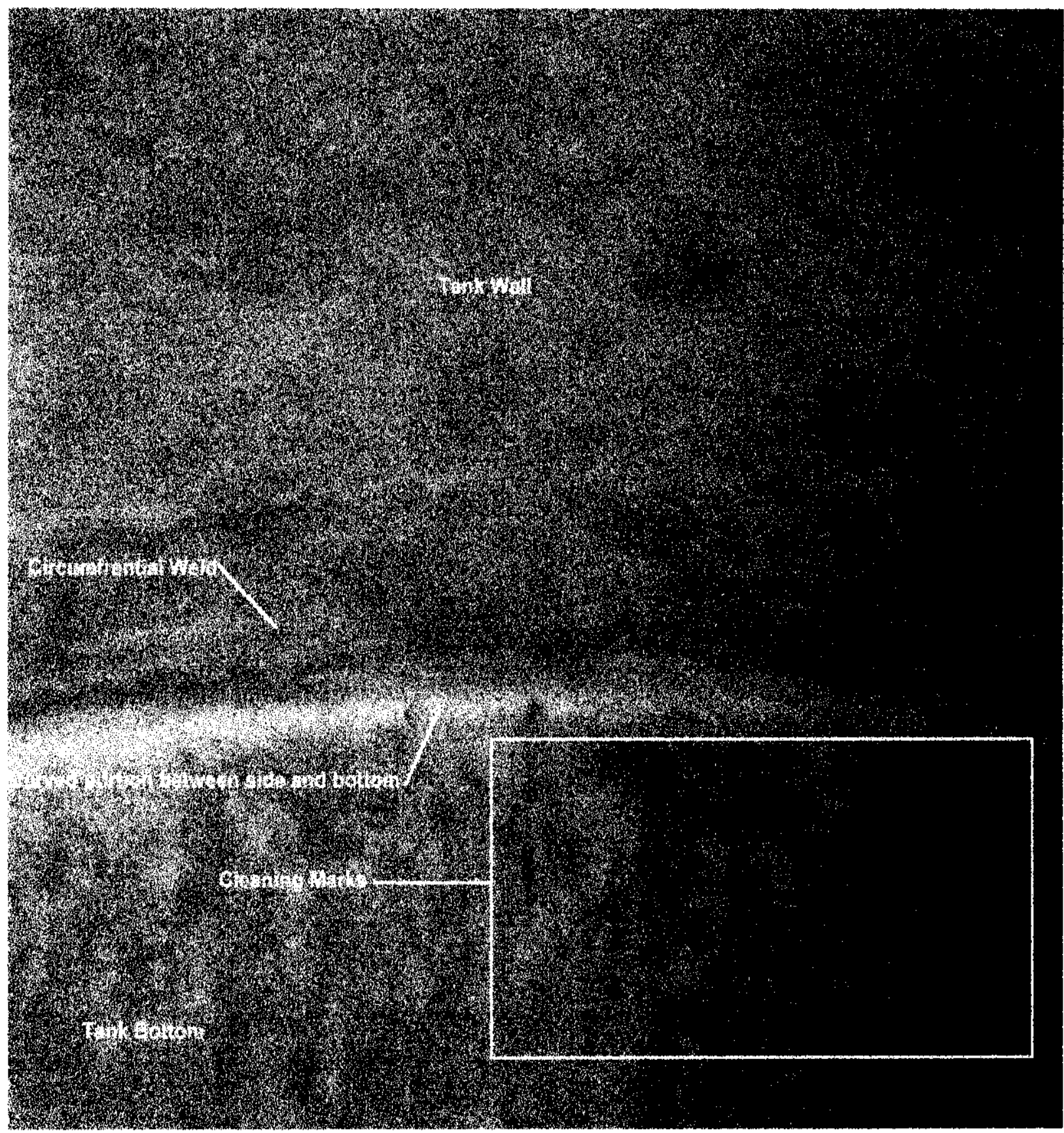

Comment: Upon further review no cracks are visible. 
FIGURE 16

POINT L TAPE \# 1

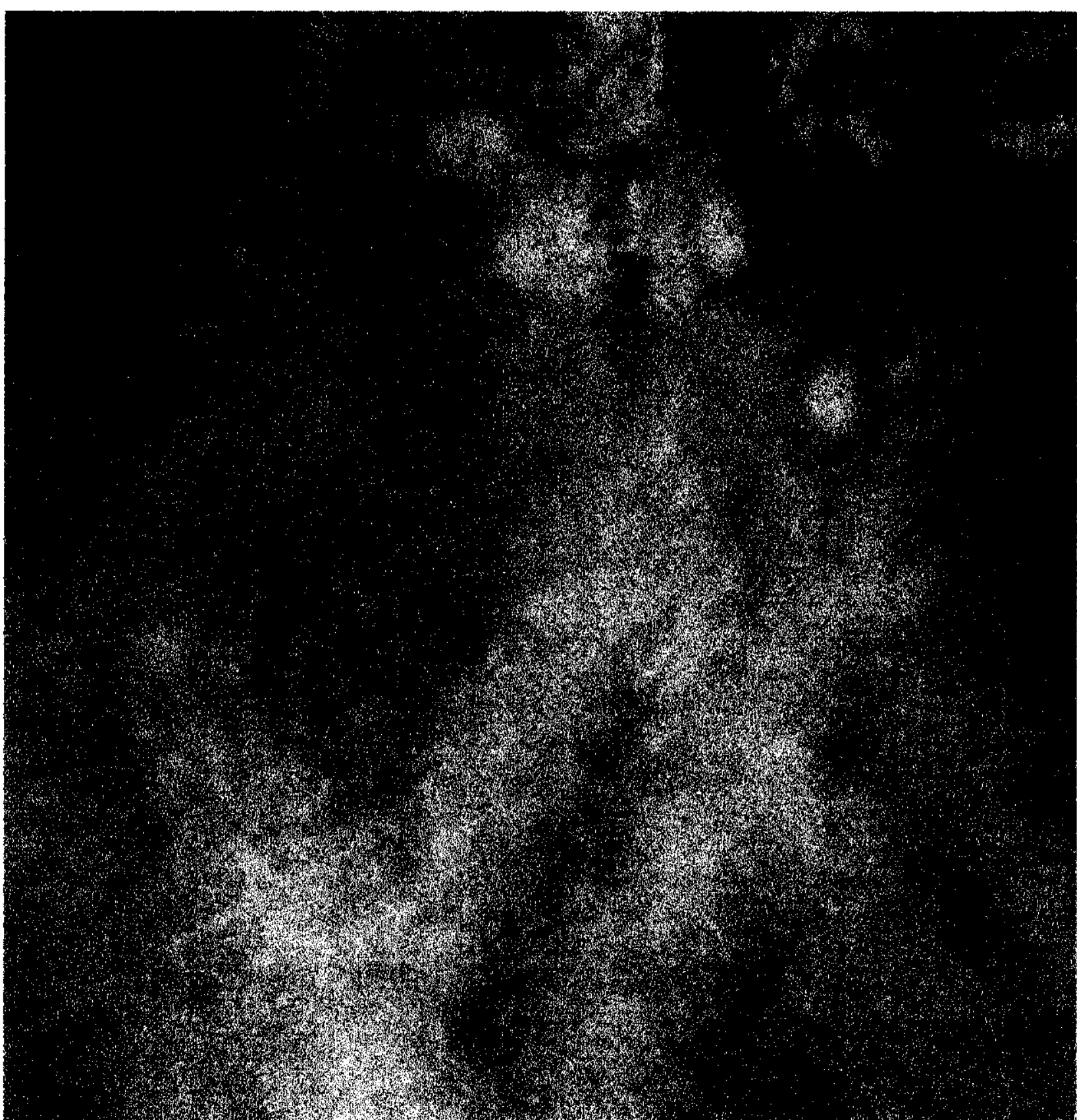

Comment: Upon further review no corrosion is visible. What is visible here is the tank with the scale that could not be removed by high-pressure water. 


\section{FIGURE 17}

\section{POINT L TAPE \# 2}

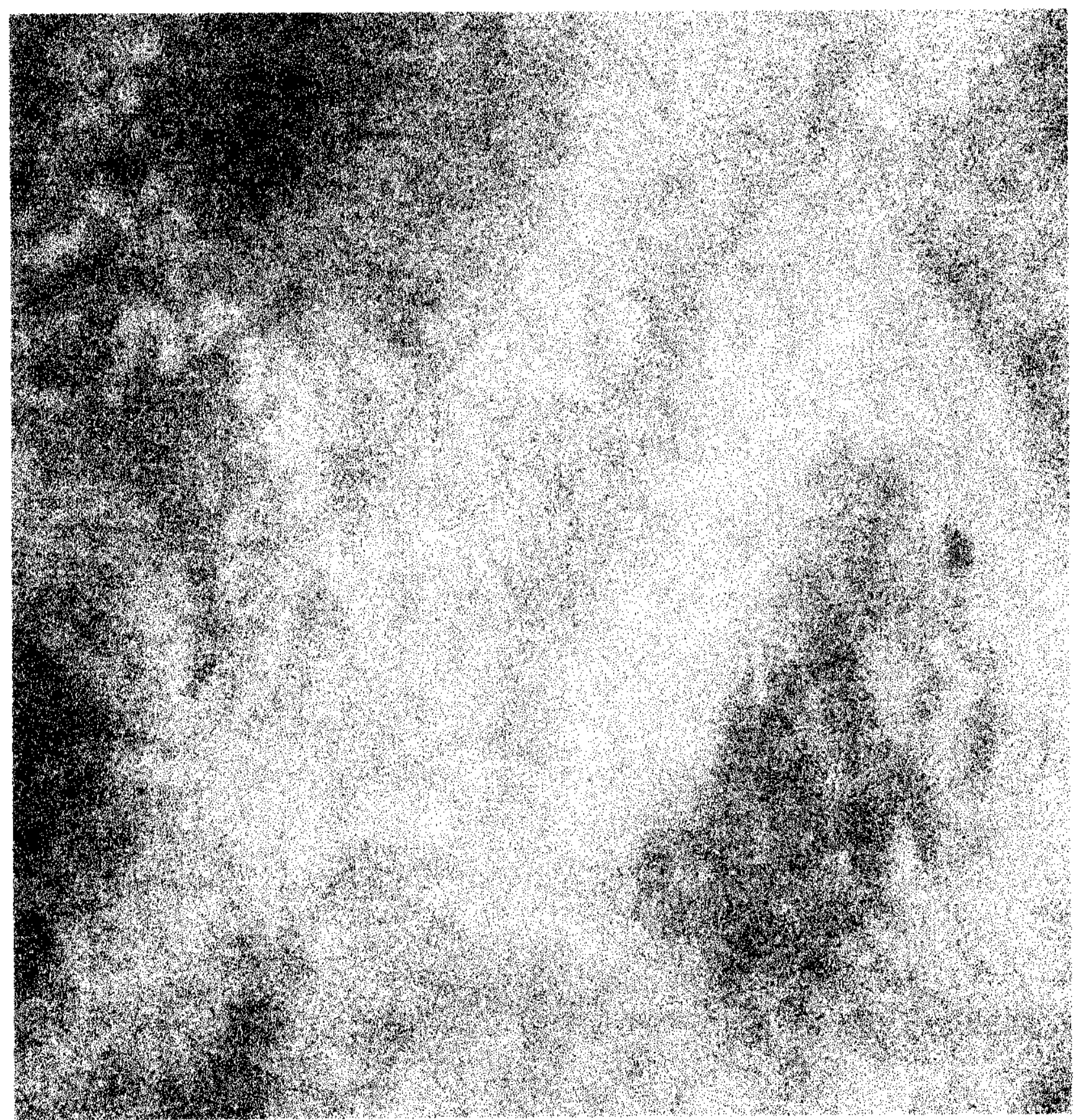

Comment: Upon further review no corrosion is visible. 
FIGURE 18

\section{POINT M TAPE \# 2}

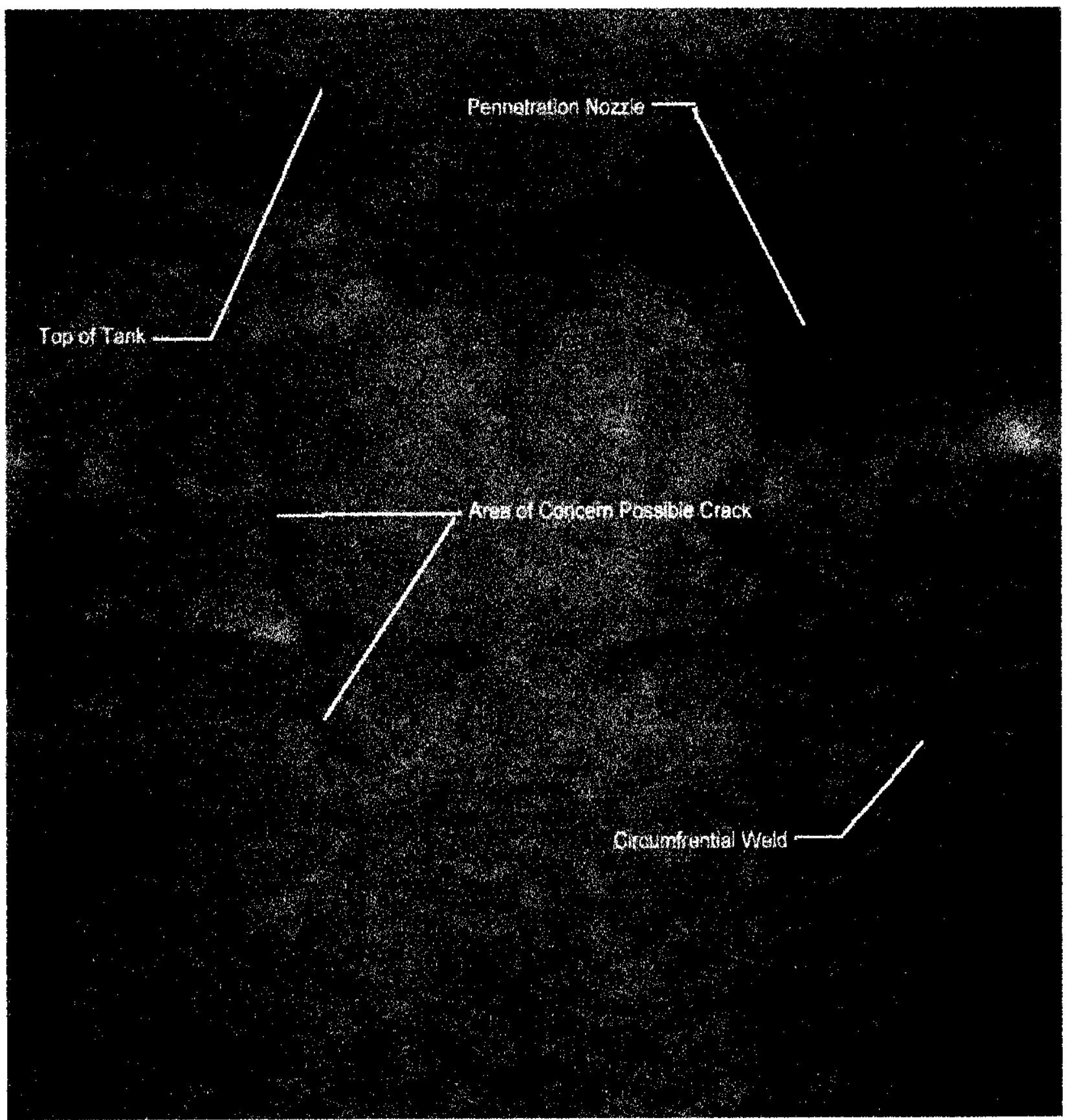

Comment: The area of concern is probably a stain. 


\section{FIGURE 19}

\section{POINT N TAPE \# 2}

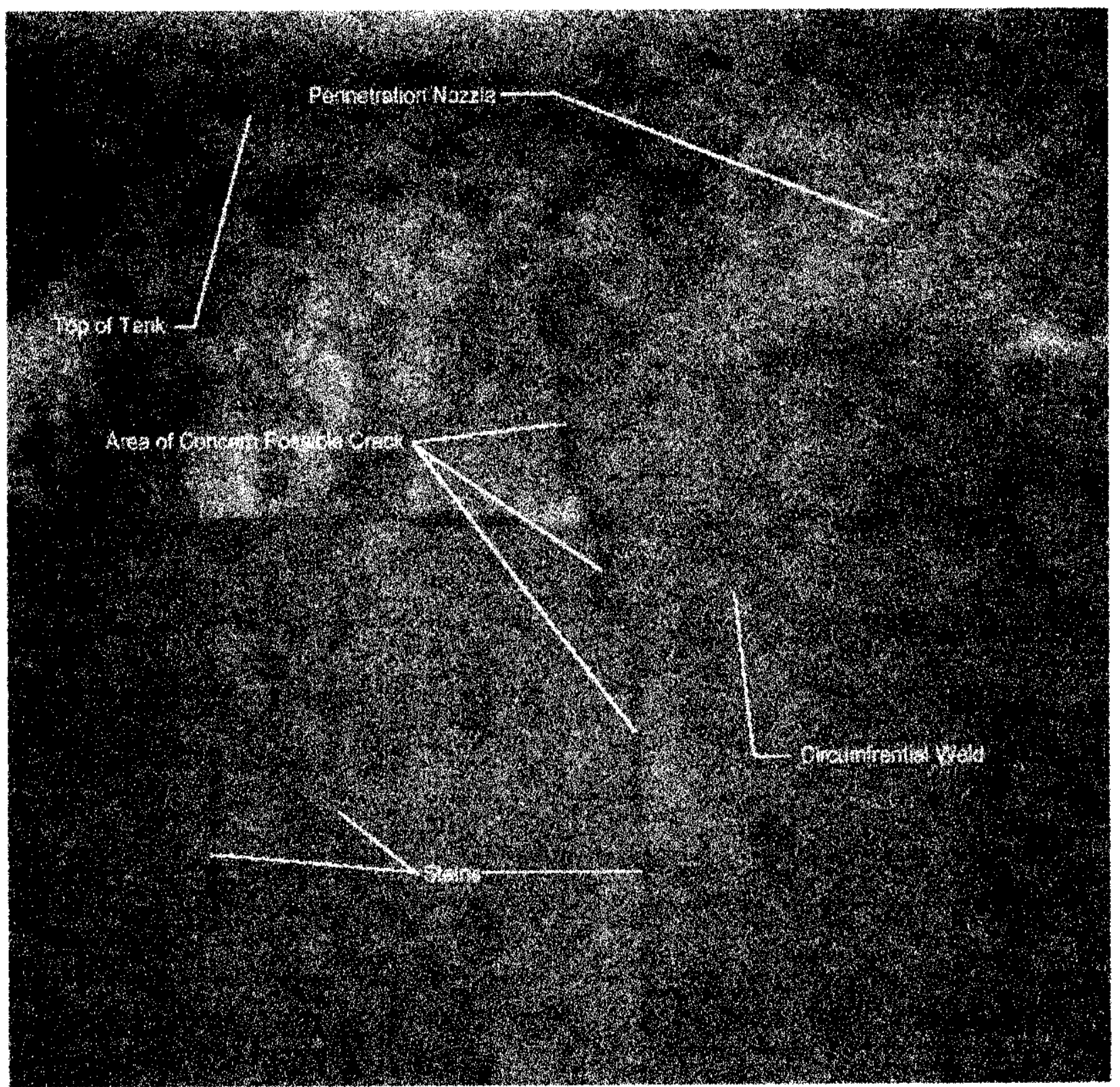

Comment: The area of concern, possible crack is just stain. There are several other stains that are all parallel. However, there is a possibility that this is a crack. 


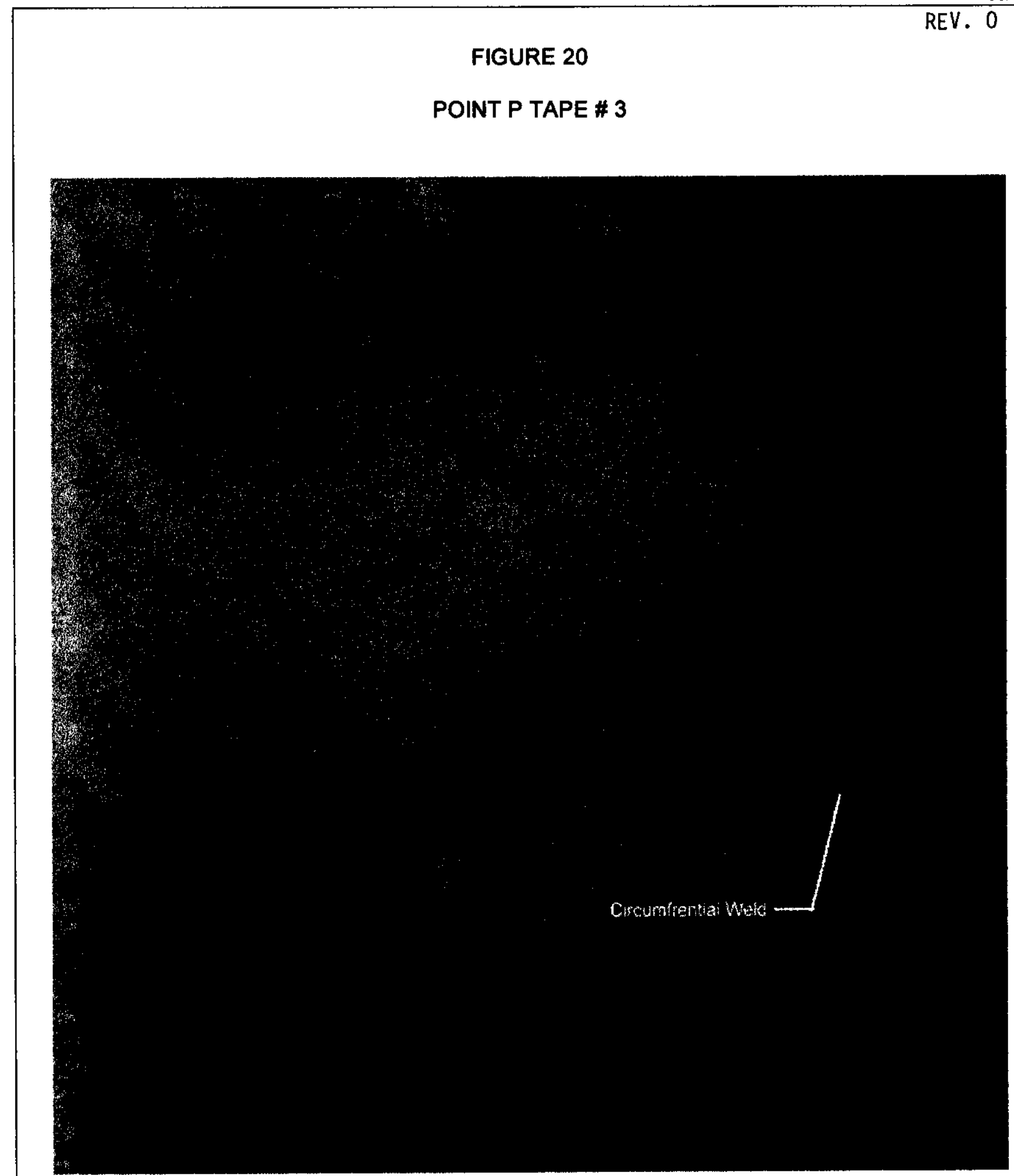

Comment: Upon further review no corrosion is present.

D-38 
FIGURE 21

POINT R TAPE \# 3

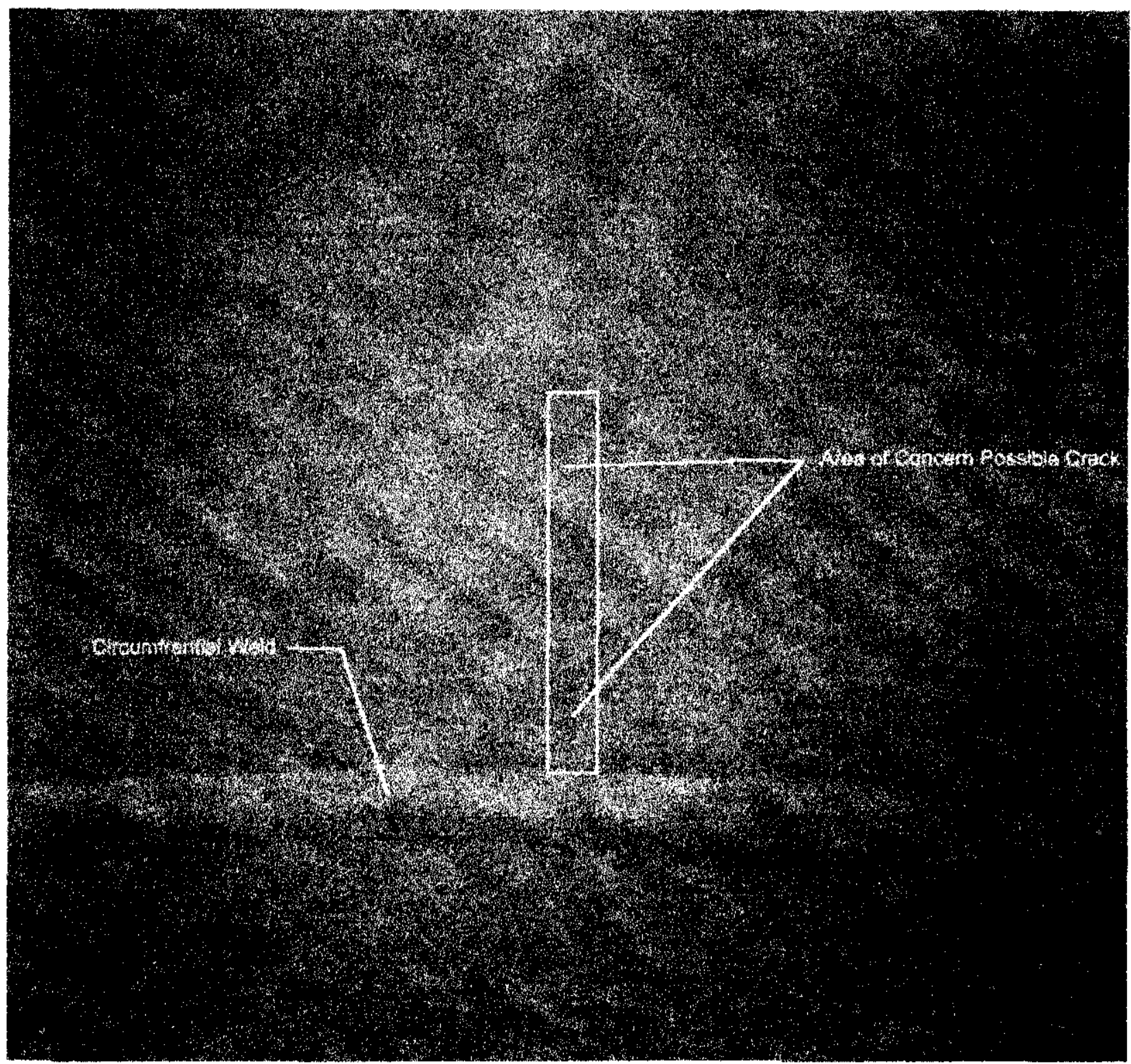

Comment: The area of concern is very faint and could be a crack. Picture from the other camera position is not available. If this is a crack the crack appears to stop at the weld. This could also be a mark or surface imperfection. 


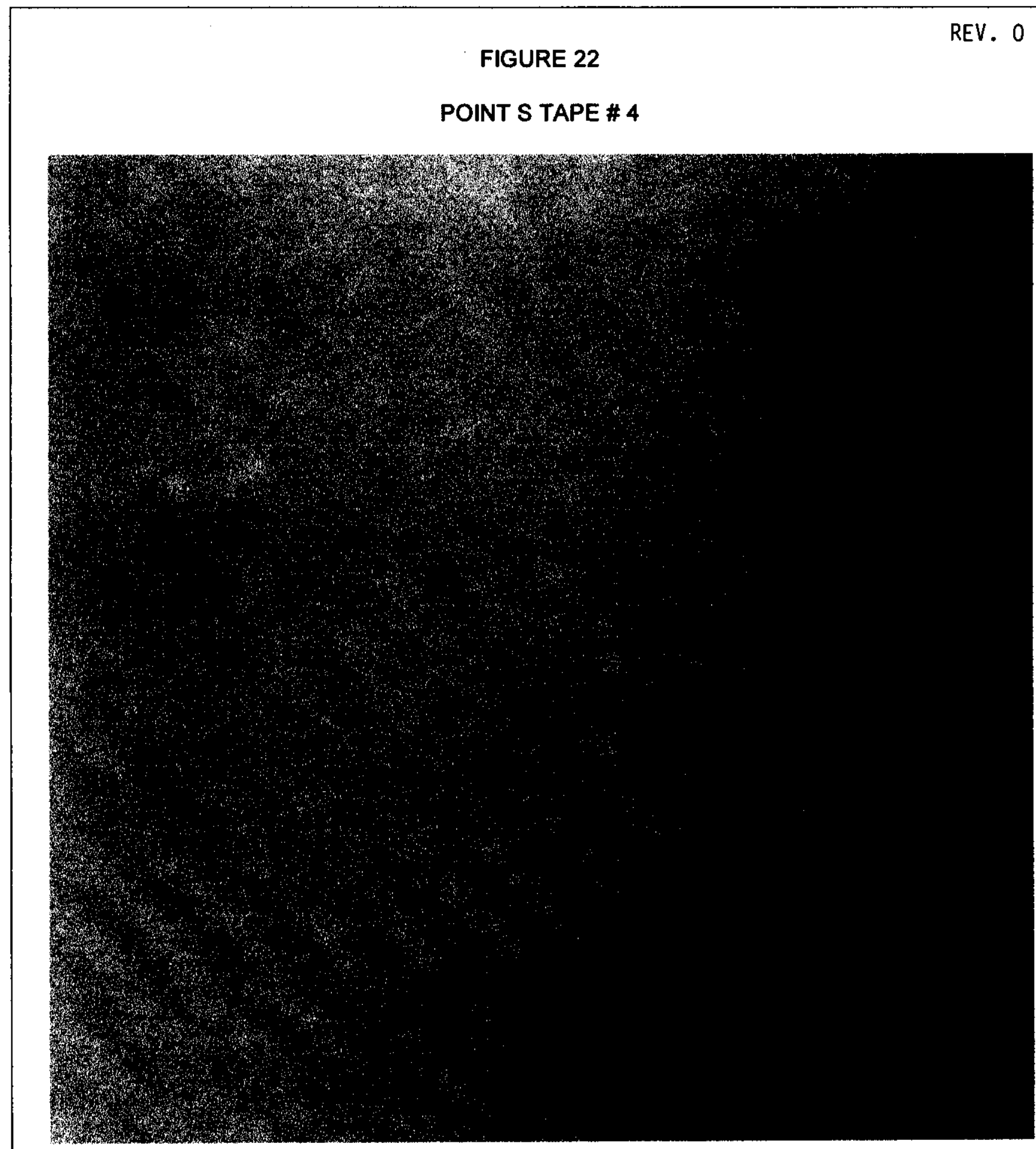

Comment: Upon further review no corrosion is visible. 
FIGURE 23

POINT S TAPE \# 3

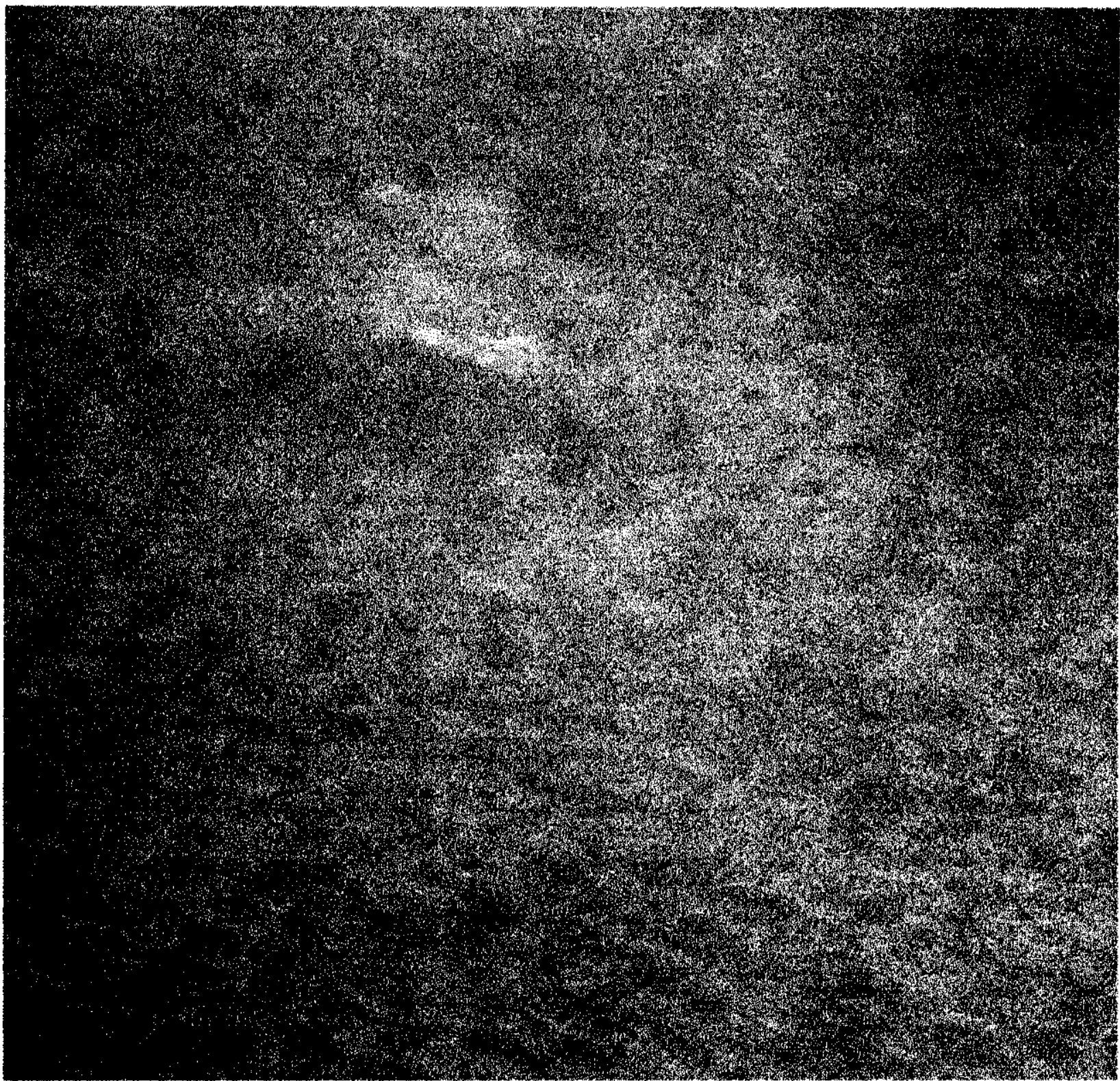

Comment: Upon further review no corrosion is visible. 


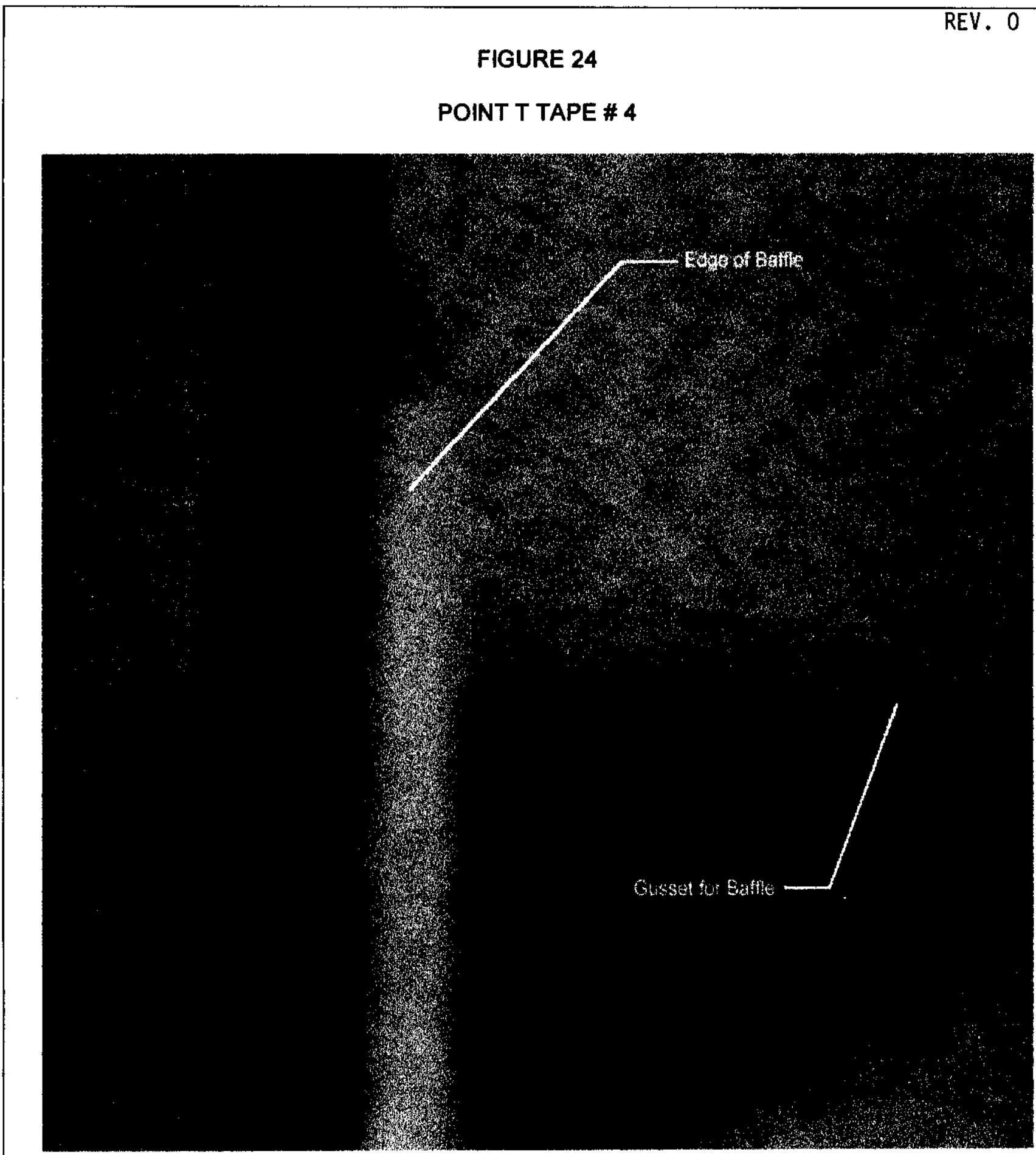

Comment: Upon further review no porosity is visible. 